\title{
Site U1342
}

\author{
Expedition 323 Scientists $^{2}$
}

\section{Chapter contents}

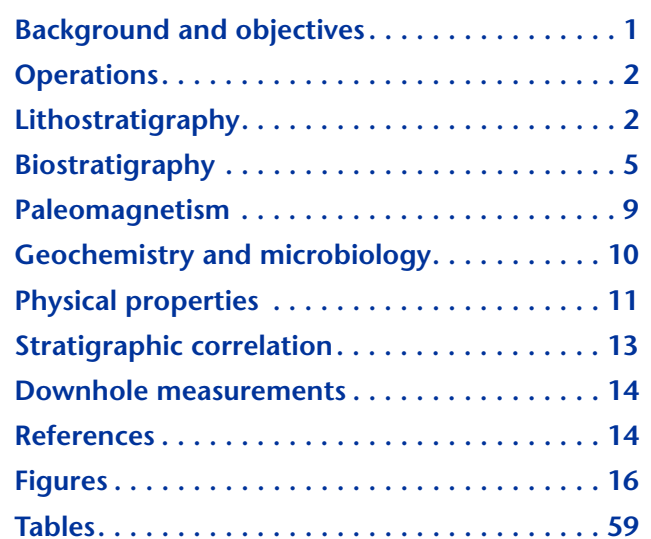

1'Expedition 323 Scientists, 2011. Site U1342. In Takahashi, K., Ravelo, A.C., Alvarez Zarikian, C.A., and the Expedition 323 Scientists, Proc. IODP, 323: Tokyo (Integrated Ocean Drilling Program Management International, Inc.). doi:10.2204/iodp.proc.323.106.2011 'Expedition 323 Scientists' addresses.

\section{Background and objectives}

The primary objective of drilling at Integrated Ocean Drilling Program (IODP) Site U1342 (proposed Site BOW-15A; Takahashi et al., 2009) was to study high-resolution Pliocene-Pleistocene paleoceanography at a relatively shallow water depth on Bowers Ridge (Fig. F1), where relatively low sedimentation rates were observed in an earlier site survey piston core study (Takahashi, 2005). Bowers Ridge is well situated to study the past extent of water mass exchange with the Pacific Ocean through adjacent Aleutian passes such as Amukta, Amchitka, and Buldir (Figs. F2, F3, F4, F5). As at other Bowers Ridge sites, the record of changes in the flow of the warm Alaskan Stream water mass into the Bering Sea and its impact on the distribution of past sea ice coverage (Katsuki and Takahashi, 2005) is of particular interest.

A previous site survey piston core study found more open water conditions during the Last Glacial Maximum (LGM) at proposed Site BOW-8A (Takahashi et al., 2009), which is located in almost the same spot as Site U1342, than at Site BOW-12A, near the ridge crest where IODP Site U1340 is located (Fig. F1). Although productivity in the Bering Sea in general is very high with respect to other parts of the global oceans, expected productivity at this site, as well as the other Bowers Ridge sites, is lower than at IODP Site U1339 on Umnak Plateau, which is substantially more influenced by the adjacent Bering Sea shelf. With its relatively shallow water depth of $818 \mathrm{~m}$, Site U1342 is the shallowest of the Bowers Ridge sites (Site U1340, water depth $=1295 \mathrm{~m}$, and IODP Site U1341, water depth $=2140 \mathrm{~m}$ ); therefore, Site U1342 provides an important constraint on the intensity and depth of the water column oxygen minimum zone (OMZ). A previous site survey piston core study reported sedimentation rates of $\sim 32 \mathrm{~m} / \mathrm{m}$.y. (Takahashi, 2005), and Pliocene-age sediments at the bottom of the sedimentary section are expected.

This drill site at Bowers Ridge can also be used to study the impact of subseafloor microbes on biogeochemical fluxes. Organic-fueled subseafloor respiration and its impact on biogeochemistry in such a highly productive region have not previously been quantified. To do so, sediments drilled at Site U1342 will be used to determine subseafloor cell abundances and to investigate the link between the mass and characteristics of subseafloor microbes and the extent of export productivity from the surface ocean (Takahashi et al., 2000). Compared to other IODP Expedition 323 drill 
sites where detailed microbiological studies took place, Site U1342 is expected to have lower (but still high) surface-ocean productivity. As such, because of its more open ocean location farthest away from the high-productivity zone of the shelf, Site U1342 serves as the low-productivity end-member of the expedition's microbiological study.

\section{Operations}

Four holes were drilled at Site U1342 (Table T1). The first was cored using the advanced piston corer (APC) system to refusal. When refusal was met early, the extended core barrel (XCB) system was deployed to confirm formation material. The $\mathrm{XCB}$ recovered $0.5 \mathrm{~m}$ of basalt, effectively ending Hole U1342A. The second hole (U1342B) was dedicated to microbiology. Hole U1342C was cored with the APC system to $45.4 \mathrm{~m}$ drilling depth below seafloor (DSF), and Hole U1342D was APC cored to $44.0 \mathrm{~m}$ DSF. At that point, a center bit was dropped and the hole was drilled ahead $18.6 \mathrm{~m}$ to determine if the basalt was continuous. At a drilling break, the XCB system was deployed and used to take 13 cores of hard rock to the total hole depth of $127.7 \mathrm{~m}$ DSF. A complete set of site-specific tide tables was provided by the science party for Site U1342. These tables were used to make adjustments relative to initial mudline core and for each successive core in each hole. APC coring totaled $182 \mathrm{~m}$ penetrated, with $194.11 \mathrm{~m}$ recovered (a core recovery of $106.7 \%)$. XCB coring for Site U1342 totaled $66.1 \mathrm{~m}$ penetrated, with $41.54 \mathrm{~m}$ recovered (62.8\% core recovery). The total cored interval was $248.1 \mathrm{~m}$, with $235.65 \mathrm{~m}$ of core recovered, for a $95 \%$ total core recovery. The time spent at Site U1342 was $33.25 \mathrm{~h}$ (1.4 days).

\section{Hole U1342A}

Hole U1342A was spudded at $1320 \mathrm{~h}$ on 3 August 2009 (all times are ship local time, Universal Time Coordinated [UTC] - $11 \mathrm{~h}$ ). The first APC barrel recovered $1.8 \mathrm{~m}$ of sediment, and an official seafloor depth was established at $829.7 \mathrm{~m}$ drilling depth below rig floor (DRF). APC coring continued through Core 323-U1342A-8H to $49.3 \mathrm{~m}$ DSF. Coring with the APC system was suspended after two successive short, incomplete strokes of the core barrel and apparent refusal. Three meters of hole was then drilled without coring with the APC/XCB bit, and the XCB system was deployed for a short core $(1 \mathrm{~m})$ to identify the material at APC refusal. Basalt was recovered and Hole U1342A was terminated. Overall core recovery for Hole U1342A using the APC coring system was $115.5 \%$, with $56.93 \mathrm{~m}$ recovered. Core re- covery using the XCB coring system was $46 \%$, with $0.46 \mathrm{~m}$ recovered.

\section{Hole U1342B}

The vessel was offset $20 \mathrm{~m}$ east of Hole U1342A, and Hole U1342B was spudded at 2315 h on 3 August. The barrel recovered $5.33 \mathrm{~m}$ of core, and an official seafloor depth was established at $830.4 \mathrm{~m} \mathrm{DRF}$. APC coring continued through Core 323-U1342B-5H to $43.3 \mathrm{~m}$ DSF.

\section{Hole U1342C}

The vessel was offset $20 \mathrm{~m}$ east of Hole U1342B, and Hole U1342C was spudded at 0235 h on 4 August. The first APC barrel recovered $7.2 \mathrm{~m}$ of core, and an official seafloor depth was established at $830.3 \mathrm{~m}$ DRF. APC coring continued through Core 323U1342C-6H to refusal. Overall core recovery for Hole U1342C using the APC coring system was $103.7 \%$, with $47.06 \mathrm{~m}$ recovered.

\section{Hole U1342D}

The vessel was offset $20 \mathrm{~m}$ east of Hole U1342C, and Hole U1342D was spudded at $0830 \mathrm{~h}$ on 4 August. The first APC barrel recovered $6.0 \mathrm{~m}$ of core, and an official seafloor depth was established at $829.7 \mathrm{~m}$ DRF. APC coring continued through Core 323U1342D-5H to $44.0 \mathrm{~m}$ DSF. On reaching refusal, the center bit was dropped and the hole was drilled ahead $18.6 \mathrm{~m}$ to see if there were sediments under the layer of hard rock (basalt). After a drilling break was observed, the XCB coring system was deployed and used successfully to core an additional $65.10 \mathrm{~m}$ into the formation. Overall core recovery for Hole U1342D using the APC coring system was $102.9 \%$, with $45.29 \mathrm{~m}$ recovered. The XCB coring system recovered $41.08 \mathrm{~m}$, for $63.1 \%$ core recovery.

\section{Lithostratigraphy}

Four holes were drilled at Site U1342; the deepest, Hole U1342D, reached 127.7 meters below seafloor (mbsf) and recovered basement rocks composed of dominantly volcaniclastic sedimentary rock below 62.6 mbsf. The sediments recovered at Site U1342 are a mixture of biogenic (mainly diatom frustules and foraminifers, with minor amounts of nannofossils, silicoflagellates, sponge spicules, and radiolarians), volcaniclastic (fine to coarse ash), and siliciclastic (clay- to pebble-sized clasts) sediments. In general, the color of the sediment reflects its lithologic characteristics: sediment composed of siliciclastic sediment or mixed lithologies tends to be very 
dark greenish gray to dark gray, whereas biogenic sediment is olive-gray to olive. Volcaniclastic ash layers are dark gray to black or shades of light gray to white. The recovered sediments and volcanic and volcaniclastic sedimentary rock are classified into three units based on major lithologic changes. The bottom boundary of Unit I (sediment composed mainly of diatoms, silt, and clay) is defined by a sharp change in grain size and diatom abundance. Unit II is predominantly sandy silt and silty sand. The bottom of Unit II is the contact between unconsolidated sediments and basement rock (Unit III), where drilling commenced.

\section{Description of units}

\section{Unit I}

Intervals: Sections 323-U1342A-1H-1, $0 \mathrm{~cm}$, through $5 \mathrm{H}-4,48 \mathrm{~cm} ; 323-\mathrm{U} 1342 \mathrm{C}-1 \mathrm{H}-1,0 \mathrm{~cm}$, through 5H-2, $17 \mathrm{~cm}$; and 323-U1342D-1H-1, 0 $\mathrm{cm}$, through $5 \mathrm{H}-3,40 \mathrm{~cm}$

Depths: Hole U1342A, 0-35.3 mbsf; Hole U1342C, 0-37.0 mbsf; and Hole U1342D, 0-37.9 mbsf

Age: Pleistocene

Unit I is composed of two alternating, mainly siliciclastic and biogenic lithologies: silty clay to clayey silt and diatom ooze (Figs. F6, F7, F8) and is similar to Unit I described at other sites. The main siliciclastic lithologies are diatom-bearing to diatom- and foraminifer-rich silty clay or clayey silt. These lithologies tend to be very dark gray to olive-gray (5Y 4/1, $10 \mathrm{Y} 4 / 1,5 \mathrm{Y} 3 / 2,5 \mathrm{Y} 3 / 1$, and $10 \mathrm{Y} 3 / 1$ ). The main biogenic lithology is olive foraminifer-rich diatom ooze with variable amounts of dispersed vitric ash. The biogenic ooze is frequently laminated and ranges from olive to olive-gray ( $5 \mathrm{Y} 4 / 3,5 \mathrm{Y} 4 / 4$, and $5 \mathrm{Y} 4 / 2)$. Foraminifers occur scattered throughout all lithologies. The preservation of siliceous microfossils is poor in the siliciclastic lithologies (see "Biostratigraphy").

The most dominant sedimentary features are thin to thick laminations that occur frequently in foraminifer-rich diatom ooze and occasionally contain nannofossils or silicoflagellates. Laminations are generally parallel, but occasionally cross-laminations occur. Laminated diatom ooze generally has a gradational top boundary characterized by burrows or mottling, whereas the lower boundary is either gradational or sharp. In some cases, a distinct, nearly monospecific layer of pennate diatoms (Lioloma pacifium) occurs at the bottom of the layer. Pennate diatom laminae are subhorizontal and are visible at the lower boundaries of laminated diatom ooze. These laminae are similar to those observed in Hole U1340D (Fig. F10 in the "Site U1340" chapter).

Fifty laminated intervals were described in Holes U1342A, U1342C, and U1342D. Nineteen of these were correlated between all holes based on their core composite depth below seafloor (CCSF-A), lamina thickness, and other visual characteristics (Fig. F9). The remaining 31 laminated layers were recognized in only one or two holes. In these intervals, slightly to moderately bioturbated diatom ooze is likely to occur in the other hole without apparent lamination (Figs. F9, F10).

Bioturbation varies from slight to moderate throughout the unit and is typically characterized by a mottling defined by color or texture changes. Typically, individual burrows are well preserved at the upper boundary of the laminated intervals and even within the laminations. Where recognizable, trace fossils were mostly assigned to the Chondrites and Skolithos ichnofacies.

Clasts occur throughout the unit and do not appear to be associated with any particular lithology. Distinct ash layers occur mainly between 20 and 40 mbsf in all holes. Volcanic ash layers are gray (5YR 6/1 and $5 \mathrm{Y} 6 / 1)$, grayish brown $(2.5 \mathrm{Y} 5 / 2)$, dark grayish brown (2.5Y 4/2), and black (5Y 2.5/2).

\section{Unit II}

Intervals: Sections 323-U1342A-5H-4, $48 \mathrm{~cm}$, through 7H-5, $131 \mathrm{~cm}$; 323-U1342C-5H-2, 17 $\mathrm{cm}$, through $6 \mathrm{H}-\mathrm{CC}, 16 \mathrm{~cm}$; and 323-U1342D$5 \mathrm{H}-3,40 \mathrm{~cm}$, through $5 \mathrm{H}-\mathrm{CC}, 13 \mathrm{~cm}$

Depths: Hole U1342A, 35.3-49.3 mbsf; Hole U1342C, 37.0-45.4 mbsf; and Hole U1342D, 37.9-44.0 mbsf

Age: Pliocene to lower Pleistocene

Unit II is defined by a shift in texture from silt- to sand-sized grains and a corresponding decrease in biogenic components composed of sandy silt to silty sand (Fig. F6). The main lithologies are very dark greenish gray to gray diatom-bearing clay to sand and very dark gray to black ( $5 \mathrm{Y} 3 / 1$ to $2.5 \mathrm{~N}$ ) diatomrich sponge spicule-bearing fine-ashy sand. One dark gray ash layer is present in all three holes, and dispersed vitric ash mottles are present throughout. Isolated clasts were also observed. In general, the sediment is highly disturbed. The sand is composed of moderately to well-rounded igneous and metamorphic rock fragments, quartz, feldspar, pyroxene, sponge spicules, diatom frustules, and well-rounded glauconite grains (Fig. F11; see also "Site U1342 thin sections" and "Site U1342 smear slides" in "Core 
descriptions"). Bioturbation varies from moderate to strong throughout the unit and is characterized by large Skolithos burrows.

Because of the highly chaotic nature of the sediments, it is unclear whether the visible structures are a result of coring disturbance, slumping, or primary deposition. Bedding and parallel laminations were described in Hole U1342C; these features are also found in Holes U1342A and U1342D but were not described as such.

In Holes U1342A and U1342C (Sections 323U1342A-5H-4, $88 \mathrm{~cm}$, to 7H-CC and Sections 323U1342C-5H-CC, $0 \mathrm{~cm}$, to $5 \mathrm{H}-\mathrm{CC}, 36 \mathrm{~cm}$ ), black sand sediments are soupy and include no significant biogenic components as a result of sediment sorting by flow-in. Because of poor recovery and flow-in of sand, it is not possible to define the exact thickness of these sandy lithologic units. In Core 323-U1342A$7 \mathrm{H}$, the APC was advanced $1 \mathrm{~m}$ but recovered $7.4 \mathrm{~m}$ of sediment. In Figure F6, only $1 \mathrm{~m}$ of sediment from Core 323-U1342A-7H is illustrated to show the depth of the drilled interval (323-U1342A-8D) and the rocks recovered in Core 323-U1342A-9X. The base of Unit II is defined by the termination of APC coring at Core 323-U1342A-7H (49.3 mbsf), where the lithified basement was reached.

\section{Unit III}

Intervals: Sections 323-U1342A-8D, $0 \mathrm{~cm}$, through 9X-1 and 323-U1342D-6D, $0 \mathrm{~cm}$, through 19X-4

Depths: Hole U1342A, 49.3-53.3 mbsf, and Hole U1342D, 44.0-127.7 mbsf

Age: unknown (age will be determined by shorebased studies)

Unit III is composed of mafic volcaniclastic rocks that range from sandstone to breccia and possibly minor basalt (Fig. F12). Basalt is present only in Core 323-U1342A-7X, extending from 52.30 to 52.76 mbsf. The basalt is porphyritic and vesicular, with a very dark gray interstitial groundmass. Phenocrysts are mostly plagioclase laths as large as $6 \mathrm{~mm}(\sim 20 \%)$ and pyroxene as large as $2 \mathrm{~mm}(\sim 2 \%)$. Many phenocrysts are in glomeroporphyritic aggregates. Vesicles are ovoid to irregular in shape and have a diameter as wide as $15 \mathrm{~mm}$, with an average of $2-3 \mathrm{~mm}$. They have a pale blue-gray or white mineral coating. The groundmass consists of plagioclase laths with brown glass in the interstices.

Below the basalt are interbedded gray, green, and red volcanogenic sandstone and breccia. The contact between the basalt and sedimentary rocks was not recovered. Most of the bedding contacts recovered in the volcaniclastic interval are parallel and are more or less sharp. Thin to thick laminations are common. The sandstone and some of the breccia beds are polymictic, consisting of a range of scoriaceous (black and red), vesicular, and nonvesicular glassy and porphyritic basalt fragments and plagioclase and pyroxene crystals. Monomict breccias with irregularly shaped porphyritic and vesicular mafic clasts are also present. Breccia clasts range from very angular to subangular and, less frequently, subrounded. Some mafic clasts have alteration rims, and rare clasts in the polymict breccia have cored lapilli consisting of a central mafic rock fragment and a coating of basalt. Most mafic clasts have flow-aligned plagioclase laths. The matrix of both breccia types is made up of glassy fragments. Most beds are moderately to well sorted, and some sandstone beds have dewatering structures. Some breccia beds are more poorly sorted. Beds are both massive and normally graded. One of the most common sedimentary structures in the laminated volcaniclastic layers is soft-sediment deformation. Tightly folded and tilted volcaniclastic beds were observed in Sections 323-U1342D-10X-2, 9X-2, 10X-3, and 12X-2. Faulted volcaniclastic layers showing $\sim 3 \mathrm{~cm}$ of apparent vertical displacement (throw) were also observed; the largest was found in Section 323-U1342D-12X-2 above a slightly slumped interval (Fig. F13). The relative offset of the hanging wall and footwall indicates that this is probably normal faulting produced in an extensional regime. Based on regional information from the Aleutian Ridge, the volcanic basement rock of Bowers Ridge probably first formed in the Eocene and ceased to accumulate in the Miocene.

\section{Discussion}

Unit I is characterized by repeated alternations between laminated foraminifer-rich diatom ooze layers and siliciclastic layers. The occurrence of well-preserved laminations indicates the absence of bioturbating fauna and thus suggests low-oxygen conditions in bottom waters and within the surface sediments. Burrows or mottles at the gradational tops of laminated sediment intervals indicate an increase in oxygenation of bottom waters after the deposition of laminated sediments. In contrast, the sharp bottom boundaries could be the result of a decrease in bottom water oxygen and cessation of bioturbation at the onset of laminated intervals or a hiatus between the laminated sediments and underlying siliciclastic sediments. Occasional cross laminations indicate either migration of sediment by bottom currents or soft-sediment deformation. The sedimentation rate at this site is on average very low (3 cm/k.y.) (see "Paleomagnetism"). The winnow- 
ing of sediment by bottom currents may have caused the apparent low average sedimentation rate, and the sedimentary record may have inherited strongly variable sedimentation rates or even phases of nondeposition or erosion.

High values in color reflectance parameter $b^{*}$ correlate well with the laminated sediments in all holes (Fig. F14) because of the difference in color between siliciclastic sediments (dark gray to greenish gray) and diatom ooze (olive). Sudden changes in $b^{*}$ were also recognized at depths where prominent laminated intervals were found in other holes. The nonlaminated intervals are generally slightly to moderately bioturbated diatom oozes. This bioturbation indicates that these nonlaminated diatom oozes are likely the result of postdepositional bioturbation of the laminated structure (see example in Fig. F10) and might represent similar depositional conditions as their laminated equivalents.

The total number of well-correlated laminated intervals (16) is similar to the total number of interglacial cycles (15) that occurred during the last $1.1 \mathrm{~m} . \mathrm{y}$. (Lisiecki and Raymo, 2005). This match suggests that the changes controlling laminations occur on the same timescale as glacial-interglacial cycles. The laminations may be related to high biological production in the surface waters and elevated organic matter export, which create anoxic bottom water conditions that prevent bioturbation of the sediments by macrofauna. Biological production tends to increase during interglacial periods in the Bering Sea (Okazaki et al., 2005). A preliminary interpretation is that the occurrence of laminated ooze reflects interglacial times. This interpretation is consistent with the preliminary paleomagnetic age model (see "Paleomagnetism"). However, this interpretation is tentative because these laminated intervals have not yet been well dated.

Unit II is characterized by its sandy texture with low abundances of biogenic components (Figs. F6, F7, F8). Moderately to well-rounded and mixed volcaniclastic and metamorphic mineral or rock fragments in the sand suggest that the source is terrestrial. The contact between Units I and II is sharp. It is unclear whether the sand was redeposited from a shallower water depth by sediment gravity flows or the paleowater depth at this site was shallower than it is today. Seismic profiles that cross the crest of Bowers Ridge appear to document that its basement rock framework was truncated by wave-base erosion prior to subsidence to depths of $1 \mathrm{~km}$ and deeper. Furthermore, the age of the unit is also ambiguous. Several Miocene diatom species were observed in this unit (see "Biostratigraphy"), but the base of Unit I is dated to only 1.1 Ma. Thus, the occurrence of Mio- cene species can be explained by reworking by sediment gravity flows, an extremely low sedimentation rate, or a hiatus between Units I and II.

The basement volcanic rock (basalt) was most likely deposited as lava, as indicated by the flow alignment of the plagioclase laths and the vesicular texture. The volcaniclastic rocks beneath have a mafic volcanic source and contain both fragments and tephra fragments (scoria). The complexly zoned plagioclase shows resorbed and sieve-textured cores typical of arc lavas. The massive to graded nature of beds and the unmodified (angular) grain shapes suggest that rapid deposition by mass flows was one of the primary depositional mechanisms. However, other sedimentary structures, including the sorting of particles, soft-sediment deformation, and microfaulting, may indicate alternate depositional modes that reflect resedimentation by mass wasting of sediments having different degrees of coherence and lithification, which, together with the presence of lava flows, are common in stratovolcanoes. It is unclear at this stage whether the mass flows were subaerial or subaqueous and whether the flows are gas or water supported. The red color of many of the fragments suggests a subaerial and oxidized source, at least in part.

\section{Biostratigraphy}

Core catcher samples above $36 \mathrm{~m}$ CCSF-A at Site U1342 are dominated by diatom microfossils exhibiting high diversity and variably good to poor preservation. These samples also contain well-preserved, low-diversity assemblages of calcareous nannofossils and planktonic foraminifers typical of high latitudes, very high to low abundances of calcareous benthic foraminifers, and variable abundances of other siliceous microfossils. Palynological residues contain high to low abundances of dinoflagellate cysts, pollen, and other palynomorphs. Below 36 m CCSF-A, the majority of microfossils disappear, and samples contain only rare diatoms and palynomorphs and are barren of calcareous microfossils. Abundant sponge spicules and fragments occur. Biostratigraphy below $36 \mathrm{~m}$ CCSF-A is hampered by poor microfossil preservation. Eight biostratigraphic datum events were interpreted based on radiolarians, diatoms, silicoflagellates, and calcareous nannofossils. These, together with paleomagnetic datum events, indicate that the base of the microfossil-rich section (uppermost 36 m CCSF-A) is 1.0 Ma (Fig. F15; Table T2), giving a low sedimentation rate of $3.6 \mathrm{~cm} / \mathrm{k} . \mathrm{y}$. compared to other Expedition 323 sites. Siliceous microfossils are mainly composed of high-latitude pelagic species similar to those found at nearby Sites U1340 
and U1341. Dinoflagellate assemblages vary between low and high primary productivity indicators and indicate generally low sea-surface temperatures (SST) and low seasonal sea ice coverage. Calcareous planktonic microfossils at this site reflect a high-latitude environment, indicating variation in SST. Benthic foraminifers are dominated by species typical of environments within the OMZ. The appearance of Pliocene diatom specimens in shallow samples and Pleistocene specimens close to the basement rock suggest reworking at this site. Middle Miocene diatoms were observed below $\sim 45 \mathrm{mbsf}$, and further investigation will be needed to determine the age of the basement.

\section{Calcareous nannofossils}

All core catcher samples from Holes U1342AU1342D were sampled and examined to assess the abundance and state of preservation of calcareous nannofossils. Evaluations of the abundance of taxa within the assemblages were also made. The results (Table T3) show that Coccolithus pelagicus is the dominant taxon and is present in all samples containing calcareous nannofossils; small and medium gephyrocapsids are also frequently present. Other taxa include Emiliania huxleyi, Pseudoemiliania lacunosa, Reticulofenestra minuta, and Calcidiscus leptoporus. Reworked specimens occur in most samples from Hole U1342D, and some of these were identified as typical middle Miocene to Pliocene taxa. The sequences recovered at Site U1342 are also characterized by frequent barren intervals, particularly in all samples below $\sim 36 \mathrm{~m}$ CCSF-A (Samples 323-U1342A$6 \mathrm{H}-\mathrm{CC}$ and $7 \mathrm{H}-\mathrm{CC}, 323-\mathrm{U} 1342 \mathrm{~B}-2 \mathrm{H}-\mathrm{CC}$ through $5 \mathrm{H}-$ CC, 323-U1342C-4H-CC through 6H-CC, and 323U1342D-5H-CC and 9H-CC) and apparently at random in Holes U1342B and U1342C, hampering the continuity of the calcareous nannofossil record.

Emiliania huxleyi, which characterizes calcareous nannoplankton Zone NN21 (Martini, 1971), is present in Samples 323-U1342A-1H-CC and 323U1342D-1H-CC and 2H-CC. Therefore, these samples can be assigned to Zone NN21, which ranges from 0.29 Ma to the present. Sample 323-U1342A$3 \mathrm{H}-\mathrm{CC}$ contains $P$. lacunosa and is therefore assigned to calcareous nannofossil Zone NN19 (Martini, 1971), which ends at $0.44 \mathrm{Ma}$.

It was not possible to assign an age based on calcareous nannofossils to the sandy silt bottom sediments of Site U1342. The existence of Pliocene and middle Miocene reworked taxa in samples above this level may provide an age estimate for those sediments; however, long-distance transportation of reworked taxa cannot be discounted because warm-water Dis- coaster spp. was found among the reworked population.

\section{Planktonic foraminifers}

The $>125 \mu \mathrm{m}$ fraction of 25 core catcher samples from Holes U1342A-U1342D and an extra sample from Hole U1342C were analyzed for planktonic foraminifers (Table T4). Additionally, mudline samples from the top of Core $1 \mathrm{H}$ in all holes were analyzed using the same size fraction. High proportions of sand, sponge spicules, and diatoms were observed in the majority of samples, and Sample 323-U1342D9X-CC contains only rock fragments. The uppermost samples of Site U1342 cores (uppermost $\sim 36 \mathrm{~m}$ CCSF-A) contain dominant to few planktonic foraminifers, and samples are mostly barren of planktonic foraminifers below. The fauna is largely dominated by Neogloboquadrina pachyderma (sinistral). The frequency of subpolar species Globigerina bulloides, Globigerina umbilicata, and Neogloboquadrina pachyderma (dextral) varies between holes and cores. In Hole U1342A, both G. bulloides and N. pachyderma (dextral) are variably abundant, and $G$. bulloides is abundant in Sample 323-U1342D-4H-CC.

The dominating species at Site U1342, N. pachyderma (sinistral), is also the dominating species in the water column of the Bering Sea today (Asahi and Takahashi, 2007). The temporal variability of this species at this site shows how subpolar-polar sea-surface conditions prevailed over the last $1 \mathrm{~m}$.y. Globigerina bulloides and G. umbilicata are controlled both by temperature and food availability (Reynolds and Thunell, 1985); however, studies in the Bering Sea show that in this region these species are mostly influenced by temperature (Asahi and Takahashi, 2007).

\section{Benthic foraminifers}

More than 20 species of benthic foraminifers were recovered in 29 samples from Holes U1342AU1342D (Table T5). The majority of core catcher samples down to around Sample 4H-CC in all holes contain varyingly diverse calcareous assemblages ranging from high to low abundance. Occasionally dominant species are Cassidulina sp. and Uvigerina peregrina. Persistently occurring species include Brizalina pygmaea, Brizalina spathula, Bulimina aff. exilis, Globobulimina pacifica, and Valvulineria spp. This assemblage shows similarities to the assemblages found in the uppermost $\sim 100 \mathrm{~m}$ of Sites U1339, U1340, and U1341 and also to those within or near the OMZ in the Sea of Okhotsk (Bubenshchikova et al., 2008). This fauna is likely strongly af- 
fected by the local OMZ, and variation in species abundance is probably linked to changes in oxygen concentrations and, in turn, surface water productivity and/or intermediate water ventilation. This assemblage does not appear to reflect shallow-water (shelf) deposition.

The assemblage largely disappears from Sample $5 \mathrm{H}$ CC and below in all holes and is replaced with glauconite-rich sands likely derived from a more shallow (shelf) setting.

\section{Ostracodes}

No ostracodes were found in core catcher samples at Site U1342.

\section{Diatoms}

Diatom biostratigraphy is based on the analysis of core catcher samples from all cores from Holes U1342A-U1342D. Depth positions and age estimates of biostratigraphic marker events are shown in Figure F15 and TableT6. Diatom preservation is poor to moderate in all holes, and abundance is common to rare throughout this Pleistocene record.

Only 5-6 cores were retrieved at Site U1342 before basement was reached. Continued drilling into the rock strata provided some interludes of softer material that were analyzed for diatoms (Samples 323U1342A-7H-CC and 323-U1342B-7H-CC). However, little information could be derived from these older intervals, and clear reworking was evident from the presence of the early Pleistocene-Pliocene species Neodenticula koizumii and the Miocene species Actinocyclus ingens. The presence of this middle Miocene species suggests a minimum age of $14 \mathrm{Ma}$ (Baldauf and Barron, 1980) for the basement at this site. This datum is, however, tentative and requires further investigation.

In Holes U1342A and U1342C, the last occurrence (LO) of Proboscia curvirostris was observed in Samples 323-U1342A-3H-CC and 323-U1342C-3H-CC. This datum, however, was observed at a shallower depth in Samples 323-U1342B-2H-CC and 323-U1342D$2 \mathrm{H}-\mathrm{CC}$ and concurs with radiolarian datum Spongodiscus sp. (Table T2). Therefore, the stratigraphic marker observed at the shallower depths was used to assign an age of 0.3 Ma (Barron and Gladenkov, 1995; Yanagisawa and Akiba, 1998).

In general, diversity is higher in the $P$. curvirostris Zone in every hole, including the species Neodenticula seminae, Actinocyclus curvatulus, Thalassiosira spp. (Thalassiosira antarctica spores, Thalassiosira latimarginata s.l., and Thalassiosira oestrupii), Thalassiothrix longissima, and Porosira glacialis. In Hole U1342B, stratigraphic biomarker Thalassiosira jouseae co-oc- curs with $P$. curvirostris, and its absence in the other holes further suggests poor preservation at this site.

The last common occurrence (LCO) datum of Actinocyclus oculatus marks the following stratigraphic zonation and was not observed in any of the holes, although it was observed sporadically throughout the record. Therefore, no clear datum was defined beyond P. curvirostris Zone 11 . The LO of N. koizumii was observed in Samples 323-U1342A-5H-CC, 323U1342B-5H-CC, and 323-U1342D-5H-CC. This datum of 2.1 Ma could not be assigned because this zone is established by the LCO of N. koizumii according to Yanagisawa and Akiba (1998). Because of poor diatom preservation below Core $5 \mathrm{H}$ in all holes, biostratigraphic zonation was constrained by one species, $P$. curvirostris, which places $N$. seminae North Pacific Diatom (NPD) Zone 12 in Samples 323-U1342A$1 \mathrm{H}-\mathrm{CC}$ through $2 \mathrm{H}-\mathrm{CC}$ and 323-U1342C-1H-CC through 2H-CC (1.65-11.41 and 7.09-17.04 mbsf, respectively). In Holes U1342B and U1342D, Zone NPD12 is shallower and covers only Samples 323U1342B-1H-CC and 323-U1342D-1H-CC (0-5.33 and 0-6.11 mbsf, respectively). In general, this short interval is poorer in diatom preservation than Zone 11 and is composed of T. latimarginata s.l., T. antarctica spores, T. oestrupii, and, to a lesser extent, Rhizosolenia spp.

\section{Silicoflagellates and ebridians}

Silicoflagellate and ebridian counting was conducted in Holes U1342A and U1342D (Table T7). Silicoflagellate and ebridian preservation at Site U1342 is essentially poor to moderate and is worse than the preservation at previous sites. Zonation datum events could not be defined at this site because of low abundances, poor skeleton preservation, and limited sample numbers. Based on the observed species, the age of the uppermost four cores from Holes $\mathrm{U} 1342 \mathrm{~A}$ and U1342D is probably Pleistocene. The age of Core 323-U1342A-5H and below may be older than $2.5 \mathrm{Ma}$ based on the occurrence of Ebriopsis antiqua antiqua, assuming it is not reworked. The biostratigraphic results at this site are still unclear, but they will be revised with the increased sample numbers available for shore-based study.

\section{Radiolarians}

Radiolarian biostratigraphy is based on the analysis of core catcher samples from Holes U1342AU1342D. The radiolarian zone defined during this expedition (see "Biostratigraphy" in the "Methods" chapter) could not be determined because there was no occurrence of Stylatractus universus. However, the stratigraphy at Site U1342 (Table T8) extends from the Botryostrobus aquilonaris Zone 
(upper Quaternary) to the Eucyrtidium matuyamai Zone (middle Quaternary) in the subarctic Pacific (Kamikuri et al., 2007). Six radiolarian datums derived in the subarctic Pacific were identified at this site (Table T8). These datums indicate lower sedimentation rates $(\sim 5 \mathrm{~cm} / \mathrm{k} . \mathrm{y}$.) in the uppermost 20 $\mathrm{m}$ intervals of each hole than those at other Bowers Ridge sites (U1340 and U1341). The Amphimelissa setosa LO datum (0.08-0.10 Ma) was found only in Hole U1342C, probably because its small skeleton size passed through the $63 \mu \mathrm{m}$ mesh. Note that the occurrence of $S$. universus in Sample 323-U1342A$7 \mathrm{H}-\mathrm{CC}$ is not used as a datum because Samples 323U1342A-6H-CC and 7H-CC possibly constitute flow-in materials. Although radiolarian datums in the lower intervals are scarce, the LO of E. matuyamai (0.9-1.5 Ma) was found in Sample 323U1342B-4H-CC. This datum provides a constraint for age estimation for the lower intervals and an average sedimentation rate in Hole U1342B of 2-4 $\mathrm{cm} / \mathrm{k} . \mathrm{y}$. Below $36 \mathrm{~m}$ CCSF-A, radiolarian abundances are very low and only a few Pleistocene species were found. No Miocene radiolarian species were found in the interval.

Radiolarian abundances and preservation are shown in Table T9. Radiolarian preservation is generally moderate to poor in all samples. The preservation conditions at this site are worse than those at other Bowers Ridge sites (U1340 and U1341). In particular, radiolarian skeletons in Sample 323-U1342A-3H-CC suffered significant dissolution and appear thin and frail, similar to specimens from deep-sea sediments found below $4000 \mathrm{~m}$ water depth. The dissolution is possibly related to sediment winnowing by bottom currents (see "Lithostratigraphy"). Radiolarian abundances are common to few in all holes at Site U1342 and very few in the lower intervals. Radiolarian assemblages are similar to those found at other Bowers Ridge sites (U1340 and U1341). However, the abundance of Stylochlamydium venustum, with its fragile skeletal parts, is apparently low, suggesting poor preservation. Interestingly, Phorticium pylonium Heackel, which is abundant in tropical to subtropical Pacific waters, was found in Sample 323-U1342D-1H-CC. With its characteristic squarelike cortical shell, this specimen differs from those found at low latitudes.

\section{Palynology: dinoflagellate cysts, pollen, and other palynomorphs}

Palynological assemblages were examined in core catcher samples from Holes U1342A and U1342B (Table T10). In spite of relatively poor diatom preservation compared to Sites U1340 and U1341, samples were difficult to process because of abundant detrital and biogenic silica. Pollen grains (mostly dominated by Picea) and pteridophyte spores occur throughout the sequence, with concentrations ranging between 10 and 900 grains $/ \mathrm{cm}^{3}$. The highest abundance occurs in Samples 323-U1342A-2H-CC and 3H-CC at $\sim 11.86$ and $22.02 \mathrm{~m}$ CCSF-A, respectively. Variable pollen concentrations indicate vegetation changes in the source area and/or changes in the strength and pattern of atmospheric and/or oceanic circulation trajectories. Reworked palynomorphs are common only in Samples 323-U1342B-3H-CC and 5H-CC and likely reflect detrital input. Organic linings of benthic foraminifers are common throughout the sequence. Their abundance could be related to moderate calcium carbonate dissolution or high benthic foraminifer production.

Dinoflagellate cysts are common to abundant in most samples, with concentrations ranging between 100 and $>1000$ cysts $/ \mathrm{cm}^{3}$. However, dinoflagellate cysts are very few to rare in the sandy layer (Samples 323-U1342A-6H-CC and 7H-CC). Poor preservation of organic-walled dinoflagellate cysts in the lower part of the sequence, particularly in the sandy layer (Samples 323-U1342A-6H-CC and 7H-CC and 323U1342B-5H-CC), suggests significantly high oxygen concentrations in the bottom water, probably caused by sediment remobilization. The species composition of the assemblages is modern (Table T10), suggesting a Pleistocene age for all analyzed samples.

\section{Discussion}

Diatomaceous sediments above $\sim 36$ m CCSF-A span the last $\sim 1.2$ m.y. (Fig. F15). These sediments and those below contain occasional reworked diatoms and silicoflagellates. The age of the underlying rock strata could not be clearly defined; however, middle Miocene diatoms observed in the deepest sample (323-U1342A-7H-CC) suggest a tentative age older than $14 \mathrm{Ma}$. Biostratigraphic investigations will continue postexpedition and be improved with shorebased studies.

Planktonic foraminifer abundances are high throughout most of the record. Calcareous nannofossil abundances are low but follow the same general trend as planktonic foraminifers. At the top of the sandy silt basal unit ( $\sim 36 \mathrm{~m}$ CCSF-A), both calcareous nannofossils and planktonic foraminifers are absent (Fig. F16). Barren intervals usually coincide with coarser sediments, which probably indicates the existence of winnowing processes that washed away the finer fraction during these intervals. The barren levels also match levels with lower percentages of $\mathrm{CaCO}_{3}$. In fact, the large similarities between carbonate abundance and calcareous nannofossil records might indicate that most of the carbonate at this site accumulated within the clay fraction, as at 
Site U1341. The percentages of heavily silicified diatom valves are low throughout the section except at $\sim 42 \mathrm{~m}$ CCSF-A (Fig. F16), where there is a single peak.

Both dinoflagellate cyst assemblages and sea ice diatoms suggest low seasonal sea ice coverage, and planktonic foraminifers indicate polar to subpolar conditions (Fig. F17). In general, dinoflagellate cysts suggest high primary productivity, low SST, and seasonal sea ice coverage (Fig. F17). However, the codominance of the autotrophic-related productivity species Operculodinium centrocarpum and the heterotrophic Brigantedinium spp. in Sample 323U1342A-3H-CC could be associated with relatively low primary productivity and/or an incursion of oceanic/oligotrophic waters. Ecological interpretation of diatom assemblages at this site is complicated by the low abundance of diatoms and sample intervals and may only be resolved by higher resolution work.

Benthic foraminifers generally have high abundances, and variation in species dominance is probably related to changes in oxygen levels caused by productivity changes and/or intermediate water ventilation, although it may also have been affected by current winnowing. Figure F18 shows the variability in the proportions of two common genera, Bulimina spp. and Uvigerina spp., against gamma ray attenuation (GRA) bulk density data. Uvigerina is regarded as a shallow infaunal (intermediate oxygen) genus, and Bulimina is regarded as deep infaunal (low oxygen) (e.g., Bubenshchikova et al., 2008; Kaiho, 1994). Low-oxygen species abundance generally correlates with variations in GRA bulk density in the uppermost $\sim 9 \mathrm{~m}$ because low GRA is associated with high biogenic production rates. Low oxygen at these times suggests that productivity was a factor affecting the OMZ extent; however, the OMZ may also have been affected by intermediate water ventilation during times of low production and possibly extensive sea ice coverage. Further analysis is needed to fully understand this relationship.

\section{Paleomagnetism}

The archive halves of all sediment cores recovered at Site U1342 were measured on the three-axis cryogenic magnetometer at $2.5 \mathrm{~cm}$ intervals. Natural remanent magnetization (NRM) was measured before (NRM step) and/or after (demagnetization step) stepwise alternating-field (AF) demagnetization in peak fields of up to $20 \mathrm{mT}$. Cores from Hole U1342A were measured at NRM step and $20 \mathrm{mT}$ demagnetization step; other Site U1342 cores were measured only at $20 \mathrm{mT}$ demagnetization step to keep up with core flow.
Inclination and intensity after $20 \mathrm{mT}$ AF demagnetization from Holes U1342A, U1342C, and U1342D are plotted in Figure F19. The average inclination values are nearly $70^{\circ}$ over the normal polarity intervals, which are close to the site axial dipole inclination $\left(\sim 72^{\circ}\right)$, indicating that we can effectively remove overprint magnetization caused by the drill pipe and/or core barrel from the NRM records. All inclination records for cores from Holes U1342A, $\mathrm{U} 1342 \mathrm{C}$, and U1342D as well as the 60 point averages are plotted in Figure F20. A polarity zonation was defined from the inclination record and correlated to the polarity timescale based on micropaleontology datums (see "Biostratigraphy"). The Brunhes/Matuyama boundary and the base of the Jaramillo Subchron are clearly identified in Holes U1342A, U1342C, and U1342D. The top of the Jaramillo Subchron and both the top and the base of the Cobb Mountain Subchron are identified in Holes U1342C and U1342D but not in Hole U1342A. Three excursions were tentatively noted in Holes U1342A, U1342C, and U1342D: the Kamikatsura, Santa Rosa, and Punaruu excursions, the depths and ages of which are shown in Table T11.

Relative paleointensity estimates from Site U1341 were compared to estimates from Site U1342. Both estimates are based on normalizing the NRM after 20 mT AF demagnetization by magnetic susceptibility. Magnetic susceptibility was used as a correlation tool to determine if a reproducible relative paleointensity record could be developed for these two sites. Magnetic susceptibility and relative paleointensity for Site U1341 are plotted in Figure F21. Magnetic susceptibility and relative paleointensity for Site U1342 are plotted in Figure F22. The comparison was limited to the Brunhes Chron (last 781,000 y). It is possible to see a correlative pattern of relative paleointensity at the two sites, as indicated by the relative numbering scheme in Figures F21 and F22. However, the relative paleointensity estimates are still significantly influenced by lithologic variability and should not be considered high-resolution estimates of true geomagnetic field intensity variations.

The age-depth relationship at Site U1342 was estimated by combining the information recovered from our estimates of polarity boundaries, excursions, and relative paleointensity (Brunhes only). The ages of excursions and relative paleointensity features are assigned using estimates of how each one is related to a specific marine isotope stage (Fig. F22). The final time-depth curve is shown in Figure F23. The fine-grained hemipelagic marine sediments are estimated to have been deposited during the last $\sim 1.5$ m.y., with essentially a constant sediment accumulation rate during the last $1 \mathrm{~m} . \mathrm{y}$. 
Figure F24 summarizes rock magnetic variability in Hole U1342A. Magnetic susceptibility is shown at the top, and magnetic remanence (after $20 \mathrm{mT}$ AF demagnetization) is shown at the bottom. Note the discrete intervals where both magnetic parameters undergo more than order-of-magnitude decreases that indicate intervals of significant magnetic mineral dissolution. These intervals appear to be closely related to laminated sediment intervals, and both are probably related to enhanced rates of reduction diagenesis during those selected time intervals. The major dissolved intervals are noted in Table T12. Our chronostratigraphic estimates suggest that these dissolved intervals (and their associated laminations) occur in interglacial sediments (Table T12). A few narrow intervals of significantly stronger remanence (Table T13) are tentatively associated with authigenic greigite or ice-rafted pebbles, which always occur in glacial-stage sediments with lower porosity.

\section{Geochemistry and microbiology Interstitial water chemistry}

Samples for interstitial water analyses were retrieved from Hole U1342A at 1.48, 4.7, 14.2, 20.2, 29.7, $39.2,44.2$, and $54.2 \mathrm{mbsf}$ by the whole-round squeezing technique. Furthermore, high-resolution samples were taken from microbiology-dedicated Hole U1342B with a total number of 56 whole-round samples. To prevent oxidation, whole rounds were stored in a nitrogen-filled glove box at $7^{\circ} \mathrm{C}$ until squeezed. Aliquot samples were processed for routine shipboard analyses (see "Geochemistry" in the "Methods" chapter) and collected for shore-based analyses of sulfur and oxygen isotopes of sulfate and hydrogen sulfide, trace metals, dissolved organic carbon (DOC), and fatty acids.

\section{Chlorinity, salinity, alkalinity, dissolved inorganic carbon, and $\mathrm{pH}$}

Interstitial water chloride concentrations at Site U1342 average $543 \pm 16 \mathrm{mM}$ (Fig. F25F), and salinity ranges from 35 to 37 . Alkalinity increases subtly with depth in the uppermost $12 \mathrm{~m}$ from 3.0 to $5.1 \mathrm{mM}$ and decreases to $3.5 \mathrm{mM}$ at $54.2 \mathrm{mbsf}$ (Fig. F25C). This trend is similar to the dissolved inorganic carbon (DIC) profile (Fig. F25A). DIC concentrations range from 2.7 to $5.1 \mathrm{mM}$ in the uppermost $12 \mathrm{~m}$ and decrease to a minimum of $2.9 \mathrm{mM}$ at $54.2 \mathrm{mbsf}$. At $\sim 19$ mbsf, DIC decreases to a local minimum of $3.9 \mathrm{mM}$. Interstitial water $\mathrm{pH}$ varies between 7.4 and 8.1 , with a trend toward higher values below $30 \mathrm{mbsf}$ (Fig. F25B). Dissolved sulfate and hydrogen sulfide.
Dissolved sulfate concentrations at Site U1342 decrease from concentrations close to seawater values at 0.05 mbsf to $\sim 24 \mathrm{mM}$ below 20 mbsf (Fig. F25D). Hydrogen sulfide concentrations above the detection limit of $0.5 \mu \mathrm{M}$ were only observed sporadically and remain $<1.5 \mu \mathrm{M}$ (data not shown).

\section{Dissolved ammonium, phosphate, and silica}

Ammonium concentrations increase with depth from $0.02 \mathrm{mM}$ in the uppermost $10 \mathrm{~m}$ to maximum values averaging $0.33 \mathrm{mM}$ between 11 and $24 \mathrm{mbsf}$ (Fig. F25H). Concentrations decrease slightly below 24 mbsf. Phosphate concentrations gradually increase from $3.2 \mu \mathrm{M}$ at $0.05 \mathrm{mbsf}$ to a maximum of $22.4 \mu \mathrm{M}$ at $6.1 \mathrm{mbsf}$ (Fig. F25G). Phosphate concentrations below this depth decrease to $<5 \mu \mathrm{M}$ at 33 mbsf. Dissolved silica concentrations increase from $470 \mu \mathrm{M}$ at $0.05 \mathrm{mbsf}$ to $940 \mu \mathrm{M}$ at $25 \mathrm{mbsf}$ and then decrease to $330 \mu \mathrm{M}$ at $54 \mathrm{mbsf}$ (Fig. F26J).

\section{Dissolved calcium, magnesium, sodium, and potassium}

Dissolved calcium, magnesium, sodium, and potassium concentrations were determined by ion chromatography. Calcium concentrations increase linearly from seawater values in the uppermost centimeters to a maximum concentration of $18 \mathrm{mM}$ at 42.85 mbsf (Fig. F26A). In contrast, magnesium concentrations decrease from $52.5 \mathrm{mM}$ at $0.05 \mathrm{mbsf}$ to $<45 \mathrm{mM}$ below $30 \mathrm{mbsf}$ (Fig. F26B). Sodium and potassium behave conservatively, with average values of $467 \pm 15 \mathrm{mM}$ and $11.3 \pm 0.7 \mathrm{mM}$, respectively (Fig. F26C, F26D).

\section{Dissolved manganese, iron, barium, boron, lithium, and strontium}

Concentrations of dissolved minor elements, analyzed by inductively coupled plasma-atomic emission spectrometry (ICP-AES), are displayed in Figure F26E-F26I. Manganese concentrations increase throughout the uppermost $12 \mathrm{~m}$ to $\sim 4.6 \mu \mathrm{M}$, are fairly constant with depth to $\sim 25 \mathrm{mbsf}$, and increase again to a maximum of $9.8 \mu \mathrm{M}$ at $37 \mathrm{mbsf}$. Dissolved iron concentrations are scattered and low, with no values exceeding $15 \mu \mathrm{M}$.

Dissolved barium is below detection limit at all depths. Dissolved lithium concentrations are fairly constant $(\sim 21 \mu \mathrm{M})$, with some scatter. Dissolved boron concentrations are fairly constant in the uppermost $~ 30$ mbsf and decrease below this depth. Dissolved strontium concentrations slightly increase below 25 mbsf. 


\section{Volatile hydrocarbons}

Forty-nine headspace samples were taken adjacent to whole rounds. Methane was the only hydrocarbon gas detected, and values are $\leq 7$ ppmv (Fig. F25E).

\section{Sedimentary bulk geochemistry}

Forty-nine samples from Holes U1342A and U1342B were analyzed for solid-phase total carbon (TC), total nitrogen (TN), total sulfur (TS), and total inorganic carbon (TIC). From these analyses, total organic carbon (TOC) and calcium carbonate $\left(\mathrm{CaCO}_{3}\right)$ concentrations were calculated (see "Geochemistry" in the "Methods" chapter). $\mathrm{CaCO}_{3}$ concentrations at Site U1342 range from 0.2 to $47.6 \mathrm{wt} \%$ (average $=6.5$ wt\%) (Fig. F27A). TOC concentrations range from 0.03 to $2.19 \mathrm{wt} \%$ (average $=0.85 \mathrm{wt} \%$ ) (Fig. F27B). $\mathrm{TN}$ concentrations are $0.01-0.25 \mathrm{wt} \%$ (average $=0.11$ wt $\%$ ) (data not shown). TS concentrations are 0.01-1.35 wt $\%$ (average $=0.29 w t \%)($ Fig. F27C). The highest $\mathrm{CaCO}_{3}$ and TOC concentrations were determined for the shallowest sample collected from Hole $\mathrm{U} 1342 \mathrm{~B}$ at 0.05 mbsf. Low values of $\mathrm{CaCO}_{3}$, TOC, and TS were detected in the deepest sediment of Hole U1342A. A higher sampling resolution in Hole $\mathrm{U} 1342 \mathrm{~B}$ reveals that the values of each solid-phase constituent fluctuate within narrow depth intervals below $\sim 10$ mbsf. The variations of geochemical records were compared with the position of laminated sediment intervals, which were estimated by GRA bulk density in Hole U1342B. The results suggest that TOC and TS are markedly higher in the laminated layers (Fig. F28), in contrast to $\mathrm{CaCO}_{3}$, which is not always high. To consider the formation processes of the laminated sediment in the Bering Sea, these data will provide useful information during shore-based research. Splits of squeeze cakes were also collected and treated for shore-based analyses of bulk elemental composition, iron mineral phases, and iron-monosulfide and pyrite content and sulfur isotope composition.

\section{Microbiology}

Samples for community structure and total prokaryotic cell abundance were collected adjacent to interstitial water whole rounds at the resolution described above. Samples were fixed according to the protocol described in "Microbiology" in the "Methods" chapter.

\section{Conclusion}

Interstitial water sulfate, DIC, phosphate, and ammonium profiles indicate that the sediment at Site U1342 is characterized by low rates of anaerobic carbon mineralization predominantly driven by organ- oclastic sulfate reduction. Additionally, small increases in manganese concentrations may indicate microbial manganese oxide reduction as an additional mineralization pathway. It is more likely, however, that dissolved manganese is released during the reaction of hydrogen sulfide with Fe/Mn (oxyhydr)oxides.

In contrast to Site U1341, a deeper site on Bowers Ridge, Site U1342 sediments have one order of magnitude lower ammonium concentrations and 50\% lower phosphate concentrations. This highlights the extremely low mineralization rates at Site U1342 despite its shallower depth and similar TOC concentrations. The low extent of anaerobic carbon mineralization at this site may be attributed to the extremely low sedimentation rates (see "Biostratigraphy"). Very low sedimentation rates prolong the time that organic matter is degraded by oxic respiration and nitrate reduction in the oxic/suboxic sediment zone. This leaves refractory organic material that is inefficiently degraded during anaerobic carbon mineralization (Hulthe et al., 1998). Dissimilar ammonium and phosphate profiles indicate the removal of phosphate from the interstitial water due to the formation of solid-phase phosphate mineral phases rather than different mechanisms of production.

Solid-phase data, however, suggest that present-day interstitial water geochemistry may give limited insight into past conditions. High TOC concentrations that correlate strongly with high TS concentrations in several laminated intervals throughout the sediment column indicate events of high organic carbon input that resulted in high sulfate reduction rates and hence elevated hydrogen sulfide production. This is reflected in high pyrite (TS) concentrations.

Another striking feature at Site U1342 is the inverse relationship of the (almost linear) calcium and magnesium profiles, which indicates the influence of signals linked to the alteration of the underlying basalt on the interstitial water calcium and magnesium concentrations. Both profiles are most likely the result of diffusion between seawater and the relatively shallow basaltic basement. Low-temperature interactions of seawater with the basaltic basement, such as the dissolution of basaltic glass, calcic plagioclase, and olivine, result in the liberation of calcium, whereas the precipitation of smectite leads to the consumption of magnesium (e.g., Gieskes, 1981; Staudigel and Hart, 1983; Thompson, 1983; Lyons et al., 2000).

\section{Physical properties}

Site U1342 was spudded at a water depth of $\sim 830 \mathrm{~m}$ just south of the summit area of Ulm Plateau, a 
wave-beveled platform cresting the western end of Bowers Ridge. Seismic reflection data reveal a thin blanket of sediment overlying the ridge's basement framework, which is known from a few dredge hauls and from coring to be constructed of arc igneous rock older than middle or early late Miocene. Recovered cores from Holes U1342A-U1342D were sectioned and placed on the Special Task Multisensor Logger (STMSL) "fast track" to record whole-core magnetic susceptibility and GRA bulk density values. Core sections were allowed to warm to laboratory temperature and were then scanned on the WholeRound Multisensor Logger (WRMSL) for GRA, magnetic susceptibility, and $P$-wave measurements. Only sediment samples from Hole U1342C were collected to measure moisture and density (MAD) properties with shipboard MAD procedures.

The sediment blanket at Ulm Plateau was sampled in Hole U1342C to $\sim 45 \mathrm{mbsf}$. At this subsurface depth, basement of dominantly volcaniclastic rock was encountered. In Hole U1342D, basement was cored to a subsediment depth of $\sim 83 \mathrm{~m}$ (44-127 mbsf). The top $\sim 18.6 \mathrm{~m}$ of basement was drilled without coring, below which $13 \mathrm{XCB}$ cores recovered $\sim 41 \mathrm{~m}$ of dominantly volcaniclastic rock.

The sedimentary column was divided into two lithologic units (see "Lithostratigraphy"): Unit I (silt and laminated diatom ooze; surface to $\sim 36 \mathrm{mbsf}$ ) and Unit II (sponge spicule- and diatom-bearing sand; $\sim 36-45$ mbsf).

\section{Magnetic susceptibility}

Figure F29 shows a downhole trend of decreasing magnetic susceptibility, from a near-surface value of $\sim 100$ SI units to about half this value at $~ 35 \mathrm{mbsf}$, the base of lithologic Unit I. Below this depth, magnetic susceptibility readings in Unit II increase in steps to as high as 350 SI units at 42 mbsf. The depth profile of magnetic susceptibility readings varies somewhat rhythmically between high and low excursions ranging from $\sim 10$ to 200 SI units in Unit I and from 50 to 350 SI units in Unit II (Fig. F29).

The cyclic fluctuations in Unit I readings presumably record alternating beds of dominantly biogenic and siliciclastic components. The downhole decreasing strength of magnetic susceptibility possibly records accumulating diagenetic degradation of magnetic properties. The higher values of Unit II likely track the downhole-increasing abundance of sandy material derived from the underlying volcanic basement, which a few recovered microfossils suggest was wave-base leveled sometime in the early late Miocene (see "Biostratigraphy" and "Lithostratigraphy"). In Hole U1342D, at a within-basement depth of 73-74 mbsf (29-30 m below the sediment/basement contact), magnetic susceptibility values are much higher and average $\sim 1500$ SI units. At 116-117 mbsf ( 72-73 m into basement), magnetic susceptibility readings average $\sim 750$ SI units.

\section{GRA wet bulk density}

The WRMSL GRA data and MAD discrete sample measurements in Figure F30 show a steady increase in density with depth. The overall increase in density is from $1.35 \mathrm{~g} / \mathrm{cm}^{3}$ near the seafloor to $1.65 \mathrm{~g} /$ $\mathrm{cm}^{3}$ at $\sim 36 \mathrm{mbsf}$, which is the base of the silt and diatom ooze of Unit I. Below this depth, bulk density increases at a steeper gradient to $\sim 1.90 \mathrm{~g} / \mathrm{cm}^{3}$ just above basement at $\sim 45$ mbsf. The steeper gradient is within the sandy sediment of Unit II, which is presumably granular material derived during the final wave-beveling stage of destruction of a stratavolcano that formerly rose above Ulm Plateau. Core inspection implies that the increased density at the base of Unit II is a consequence of higher contents of siliciclastic and rock volcanic debris compared to biogenic components, in particular diatom frustules.

\section{$P$-wave velocity}

$P$-wave velocity increases downhole from near-seafloor readings of just over $1.45 \mathrm{~km} / \mathrm{s}$ to $\sim 1.55 \mathrm{~km} / \mathrm{s}$ in Unit II near the contact with basement rock at $\sim 45$ mbsf (Fig. F31). In the sandy sediment of Unit II in Hole U1342D, $P$-wave velocity increased to $\sim 1.60$ $\mathrm{km} / \mathrm{s}$ and somewhat higher. Velocity recorded in this unit is at a minimum because of serious drilling disturbance and the in-mixing of water.

\section{Natural gamma radiation}

The natural gamma radiation (NGR) readings displayed in Figure F32 increase irregularly downhole from a near-seafloor average of $\sim 18$ counts/s to $\sim 24$ counts/s at the base of Unit I. The gradient of increasing values steepens within the sandy beds of Unit II to reach $\sim 40$ counts/s just above basement contact at $\sim 44$ mbsf. The elevated NGR readings presumably record a downsection increase in clay minerals that may be derived within Unit II from the underlying bedrock of arc lava and volcaniclastic deposits. Rock clasts recovered in core sections exhibit evidence of oxidation. Clay minerals that account for the higher NGR readings in the basal sediment of Unit II presumably reflect subaerial weathering of the stratavolcano that towered above Ulm Plateau prior to its presumed early late Miocene destruction. At $\sim 72-73 \mathrm{~m}$ into basement ( 116-117 mbsf) in Hole U1342D, NGR readings are quite low, ranging from $\sim 1$ to 6 counts/s, but the cored volcani- 
clastic sandstone and breccia are commonly oxidized and red in color.

\section{MAD (discrete sample) wet bulk density}

MAD physical properties of wet and dry bulk density, moisture content, porosity, and grain density were measured on sediment samples $\left(\sim 10 \mathrm{~cm}^{3}\right)$ taken from the working halves of split core sections. The samples were routinely collected from Sections 2,4 , and 6 of Hole U1342C cores (Table T14). The measured values of wet bulk density are shown in Figure F30 as open circles plotted with WRMSL GRA bulk density. In general, MAD values track those of GRA but with much greater measurement spacing. The contrast between Unit I and denser Unit II sediments is nevertheless clearly shown by the MAD data.

\section{MAD porosity and water content}

As shown in Figure F33, sediment porosity and water or moisture content track in parallel, decreasing downhole. The near-surface porosity is $\sim 80 \%$, but porosity decreases to $\sim 55 \%$ in the sandy sediment of Unit II and just above basement at 44 mbsf. The downhole trend of overall decreasing porosity and water content presumably reflects compaction of the section, with notable excursions to higher values in the basal $10-12 \mathrm{~m}$ of Unit I that may identify higher relative content of siliceous microfossils.

\section{Grain density}

Grain density decreases downsection in Unit I from $\sim 2.82$ to $2.53 \mathrm{~g} / \mathrm{cm}^{3}$ and possibly lower (Fig. F34). Grain density in underlying Unit II (siliceous microfossil-bearing sand) rapidly increases downhole to $\sim 2.70 \mathrm{~g} / \mathrm{cm}^{3}$ as bedrock is approached. The elevated grain density in Unit I, as compared to the upper beds of Site U1341 on the deeper flank of Bowers Ridge, can be attributed to the availability of nearby bedrock sources for Site U1342 deposits. Seafloor exposures of probably pre-Miocene volcaniclastic and lava units or their occurrence in the shallow subcrop most likely occur on the summit area of Ulm Plateau, located $\sim 10 \mathrm{~km}$ northwest of Site U1342. The rapid excursion near the base of Unit I to a low density of just over $2.2 \mathrm{~g} / \mathrm{cm}^{3}$ is probably a spurious measurement.

\section{Stratigraphic correlation}

The composite depth scale and splice at Site U1342 is complete and continuous from 0.0 to $46.54 \mathrm{~m}$ CCSF-A (as defined in "Stratigraphic correlation" in the "Methods" chapter). The splice ranges from the mudline at the top of Core 323-U1342D-1H to the bottom of Section 323-U1342D-5H-7 (Tables T15, T16). Sediment cores below the splice (Cores 323$\mathrm{U} 1342 \mathrm{~A}-6 \mathrm{H}$ and $7 \mathrm{H}$ ) are included in the composite depth framework by appending them with a constant affine value of $2.78 \mathrm{~m}$. Core 323-U1342A-8D is a drilled interval with no recovery; Core 323U1342A-9X recovered hard rock and is not included in the composite depth framework, nor are drilled interval 323-U1342D-6D and Cores 323-U1342D-7X through 19X, which had partial recovery of lithified sediments and volcanic rocks.

Correlations were accomplished using IODP Correlator software (version 1.656), and some intervals were checked with digital line-scan images with Correlyzer (version 1.3.3).

The composite (CCSF-A) and splice (CCSF-D) depth scales are based primarily on the stratigraphic correlation of WRMSL magnetic susceptibility data (Fig. F35), augmented with WRMSL GRA bulk density (Fig. F36) and NGR data (Fig. F37). Color reflectance data were also examined; the $\mathrm{b}^{*}$ parameter was useful for correlation (Fig. F38), but the $\mathrm{L}^{*}$ and $\mathrm{a}^{*}$ parameters did not appear to correlate between holes (data not shown). GRA data from both the STMSL and WRMSL were calibrated prior to analyzing cores for each hole.

Construction of the CCSF-A and CCSF-D scales assumed that the uppermost sediment (the mudline) in Core 323-U1342A-1H was the sediment/water interface. A mudline was also recovered in Cores 323U1342A-1H, 323-U1342B-1H, and 323-U1342C-1H, which confirmed the fidelity of the top of the recovered section. Core 323-U1342A-1H serves as the anchor in the composite depth scale and is the only core with depths that are the same on the mbsf and CCSF-A scales. However, because Core 323-U1342A$1 \mathrm{H}$ is a short core, we chose to start the splice with the longer Core 323-U1342D-1H, whose top starts at 0.03 mbsf. From this core we worked downhole, correlating the variations in core logging data on a coreby-core basis using Correlator. Hole U1342B was assigned affine values based on comparison of its STMSL GRA and magnetic susceptibility data to the WRMSL GRA and magnetic susceptibility data from other holes; however, Hole U1342B was largely consumed by microbiology studies, so it was excluded from the splice. All affine values that define the composite depth scale and all splice tie points are robust and well defined at Site U1342. The resulting spliced records of magnetic susceptibility, GRA bulk density, and NGR are illustrated in Figure F39.

Within the splice, the composite CCSF-A depth scale is defined as the CCSF-D depth scale. Note that CCSF-D rigorously applies only to the spliced interval. Intervals outside the splice, although available 
with CCSF-A composite depth assignments, should not be expected to correlate precisely with fine-scale details within the splice or with other holes because of normal variation in the relative spacing of features in different holes. Such apparent depth differences may reflect coring artifacts or fine-scale variations in sediment accumulation and preservation at and below the seafloor.

The cumulative offset between mbsf and CCSF-A depth scales is approximately linear (Fig. F40). The affine growth factor (a measure of the fractional stretching of the composite section relative to the drilled interval; see "Stratigraphic correlation" in the "Methods" chapter) at Site U1342 is 1.06 between 0 and 44.0 mbsf. Calculation of mass accumulation rates (MARs) based on the CCSF-A or CCSF-D scales should account for this affine growth factor by dividing apparent depth intervals by the appropriate growth factor. After it is divided by the growth factor (accounting for the different depth intervals), this scaled depth scale should be referred to as CCSF-B.

\section{Downhole measurements}

The only downhole measurements made at Site U1342 were two deployments of the third-generation advanced piston corer temperature tool (APCT-3) in Hole U1342C. The measured temperature was $4.46^{\circ} \mathrm{C}$ at $26.2 \mathrm{~m}$ DSF and $5.32^{\circ} \mathrm{C}$ at $35.0 \mathrm{~m} \mathrm{DSF}$ (Table T17). These two measurements suggest a local geothermal gradient of $97.7^{\circ} \mathrm{C} / \mathrm{km}$ (Fig. F41). A simple estimate of the heat flow can be obtained from the product of the geothermal gradient by the average thermal conductivity $(0.991 \mathrm{~W} /[\mathrm{m} \cdot \mathrm{K}]$; see "Physical properties"), which gives a value of $96.9 \mathrm{~mW} / \mathrm{m}^{2}$, significantly higher than existing measurement in the area (the global heat flow database of the International Heat Flow Commission can be found at www.heatflow.und.edu/index.html).

Considering the variations in thermal conductivity with depth, a more accurate measure of the heat flow in a conductive regime can be given by a "Bullard plot." The thermal resistance of an interval is calculated by integrating the inverse of thermal conductivity over depth. If the thermal regime is purely conductive, the heat flow will be the slope of the temperature versus thermal resistance profiles (Bullard, 1939). The thermal resistance calculated over the intervals overlying the APCT-3 measurements is shown in Table T17, and the resulting linear fit of the temperature to the thermal resistance gives a heat flow value of $80.9 \mathrm{~mW} / \mathrm{m}^{2}$, which is closer to the other measurements in the Bowers Ridge area (Fig. F42).

\section{References}

Asahi, H., and Takahashi, K., 2007. A 9-year time-series of planktonic foraminifer fluxes and environmental change in the Bering Sea and the central subarctic Pacific Ocean, 1990-1999. Prog. Oceanogr., 72(4):343-363. doi:10.1016/j.pocean.2006.03.021

Baldauf, J.G., and Barron, J.A., 1980. Actinocyclus ingens var. nodus: a new stratigraphically useful diatom of the circum-North Pacific. Micropaleontology, 26:103-110. doi:10.2307/1485279

Barron, J.A., and Gladenkov, A.Y., 1995. Early Miocene to Pleistocene diatom stratigraphy of Leg 145. In Rea, D.K., Basov, I.A., Scholl, D.W., and Allan, J.F. (Eds.), Proc. ODP, Sci. Results, 145: College Station, TX (Ocean Drilling Program), 3-19. doi:10.2973/

odp.proc.sr.145.101.1995

Bubenshchikova, N., Nürnberg, D., Lembke-Jene, L., and Pavlova, G., 2008. Living benthic foraminifera of the Okhotsk Sea: faunal composition, standing stocks and microhabitats. Mar. Micropaleontol., 69(3-4):314-333. doi:10.1016/j.marmicro.2008.09.002

Bullard, E.C., 1939. Heat flow in South Africa. Proc. R. Soc. London, Ser. A, 173:474-502.

Gieskes, J.M., 1981. Deep-sea drilling interstitial water studies: implications for chemical alteration of the oceanic crust, Layers I and II. In Warme, J.E., Douglas, R.G., and Winterer, E.L. (Eds.), The Deep Sea Drilling Project: A Decade of Progress. Spec. Publ.-Soc. Econ. Paleontol. Mineral., 32:149-167.

Hulthe, G., Hulth, S., and Hall, P.O.J., 1998. Effect of oxygen on degradation rate of refractory and labile organic matter in continental margin sediments. Geochim. Cosmochim. Acta, 62(8):1319-1328. doi:10.1016/S00167037(98)00044-1

Kaiho, K., 1994. Benthic foraminiferal dissolved-oxygen index and dissolved-oxygen levels in the modern ocean. Geology, 22(8):719-722. doi:10.1130/ 0091-7613(1994)022<0719:BFDOIA >2.3.CO;2

Kamikuri, S., Nishi, H., and Motoyama, I., 2007. Effects of late Neogene climatic cooling on North Pacific radiolarian assemblages and oceanographic conditions. Palaeogeogr., Palaeoclimatol., Palaeoecol., 249(3-4):370-392. doi:10.1016/j.palaeo.2007.02.008

Katsuki, K., and Takahashi, K., 2005. Diatoms as paleoenvironmental proxies for seasonal productivity, sea-ice and surface circulation in the Bering Sea during the late Quaternary. Deep-Sea Res., Part II, 52(16-18):2110-2130. doi:10.1016/j.dsr2.2005.07.001

Lisiecki, L.E., and Raymo, M.E., 2005. A Pliocene-Pleistocene stack of 57 globally distributed benthic $\delta^{18} \mathrm{O}$ records. Paleoceanography, 20(1):PA1003. doi:10.1029/ 2004PA001071

Lyons, T.W., Murray, R.W., and Pearson, D.G., 2000. A comparative study of diagenetic pathways in sediments of the Caribbean Sea: highlights from pore-water results. In Leckie, R.M., Sigurdsson, H., Acton, G.D., and Draper, G. (Eds.), Proc. ODP, Sci. Results, 165: College 
Station, TX (Ocean Drilling Program), 287-298. doi:10.2973/odp.proc.sr.165.020.2000

Martini, E., 1971. Standard Tertiary and Quaternary calcareous nannoplankton zonation. In Farinacci, A. (Ed.), Proc. 2nd Int. Conf. Planktonic Microfossils Roma: Rome (Ed. Tecnosci.), 2:739-785.

Okazaki, Y., Takahashi, K., Asahi, H., Katsuki, K., Hori, J., Yasuda, H., Sagawa, Y., and Tokuyama, H., 2005. Productivity changes in the Bering Sea during the late Quaternary. Deep-Sea Res., Part II, 52(16-18):2150-2162. doi:10.1016/j.dsr2.2005.07.003

Reynolds, L., and Thunell, R.C., 1985. Seasonal succession of planktonic foraminifera in the subpolar North Pacific. J. Foraminiferal Res., 15(4):282-301. doi:10.2113/gsjfr.15.4.282

Staudigel, H., and Hart, S.R., 1983. Alteration of basaltic glass: mechanisms and significance for the oceanic crust-seawater budget. Geochim. Cosmochim. Acta, 47(3):337-350. doi:10.1016/0016-7037(83)90257-0

Takahashi, K., 2005. The Bering Sea and paleoceanography. Deep-Sea Res., Part II, 52(16-18):2080-2091. doi:10.1016/j.dsr2.2005.08.003
Takahashi, K., Fujitani, N., Yanada, M., and Maita, Y., 2000. Long-term biogenic particle fluxes in the Bering Sea and the central subarctic Pacific Ocean, 1990-1995. Deep-Sea Res., Part I, 47(9):1723-1759. doi:10.1016/S09670637(00)00002-9

Takahashi, K., Ravelo, A.C., and Alvarez Zarikian, C.A., 2009. Pliocene-Pleistocene paleoceanography and climate history of the Bering Sea. IODP Sci. Prosp., 323. doi:10.2204/iodp.sp.323.2009

Thompson, G., 1983. Basalt-seawater interaction. In Rona, P.A., Boström, K., Laubier, L., and Smith, K.L., Jr. (Eds.), Hydrothermal Processes at Seafloor Spreading Centers: New York (Plenum), 225-278.

Yanagisawa, Y., and Akiba, F., 1998. Refined Neogene diatom biostratigraphy for the northwest Pacific around Japan, with an introduction of code numbers for selected diatom biohorizons. Chishitsugaku Zasshi, 104:395-414.

Publication: 15 March 2011

MS 323-106 
Figure F1. Location map for Site U1342 on Bowers Ridge. DSDP = Deep Sea Drilling Project.

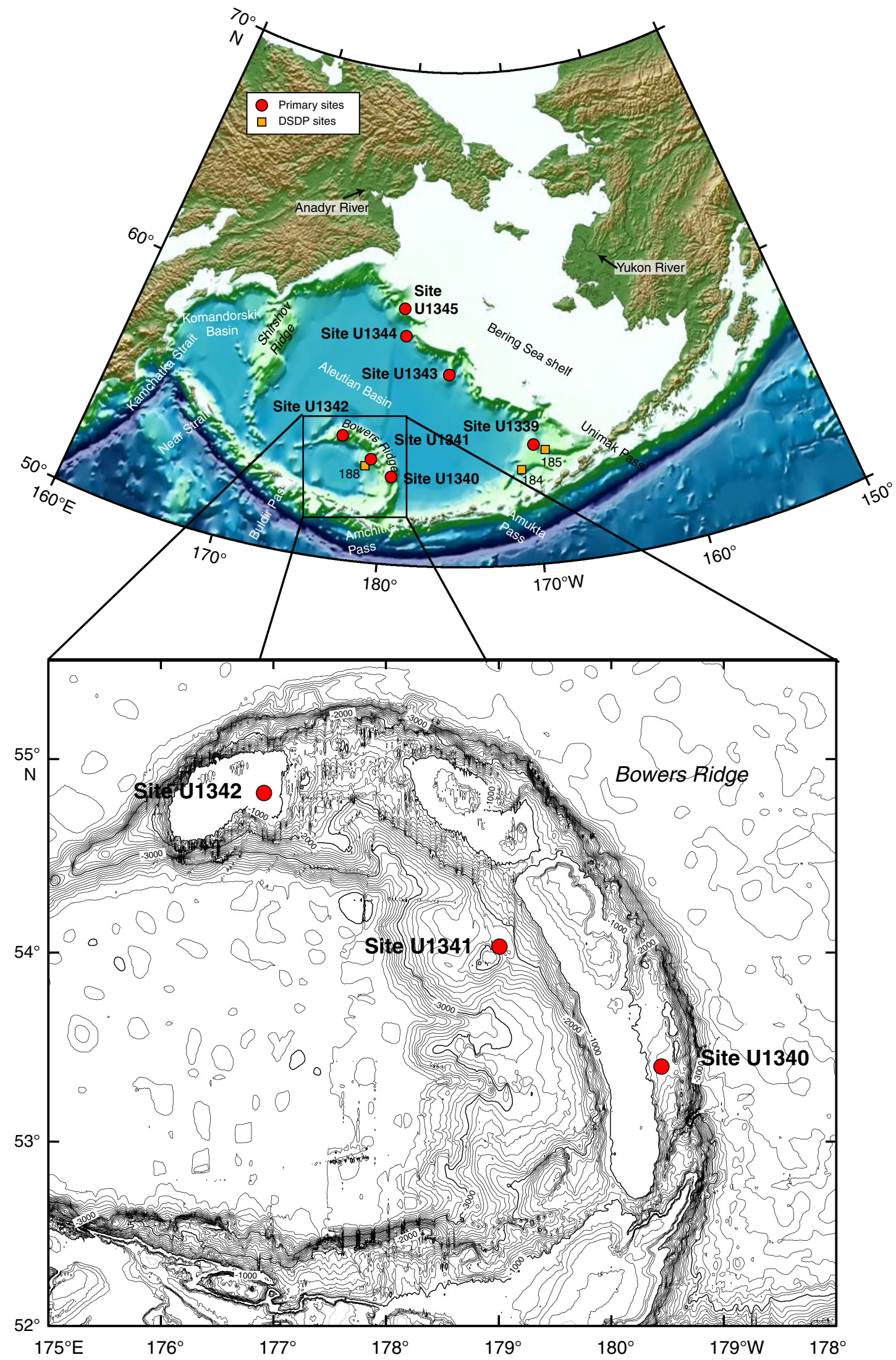




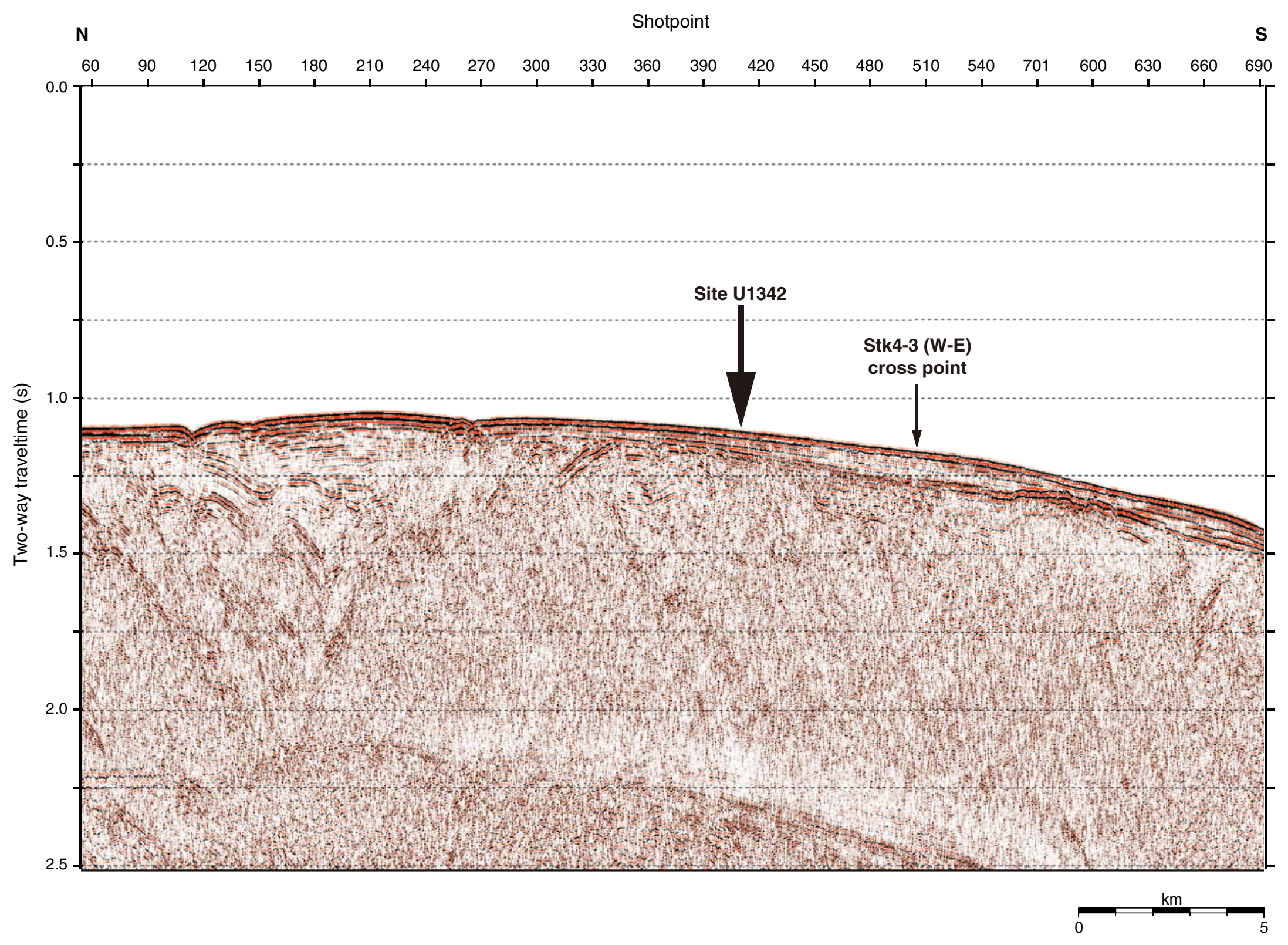


Figure F3. Navigation map of Hakuhou-Maru Cruise KH99-3 around Site U1342 for close-up seismic profiles found in Figures F4 and F5.

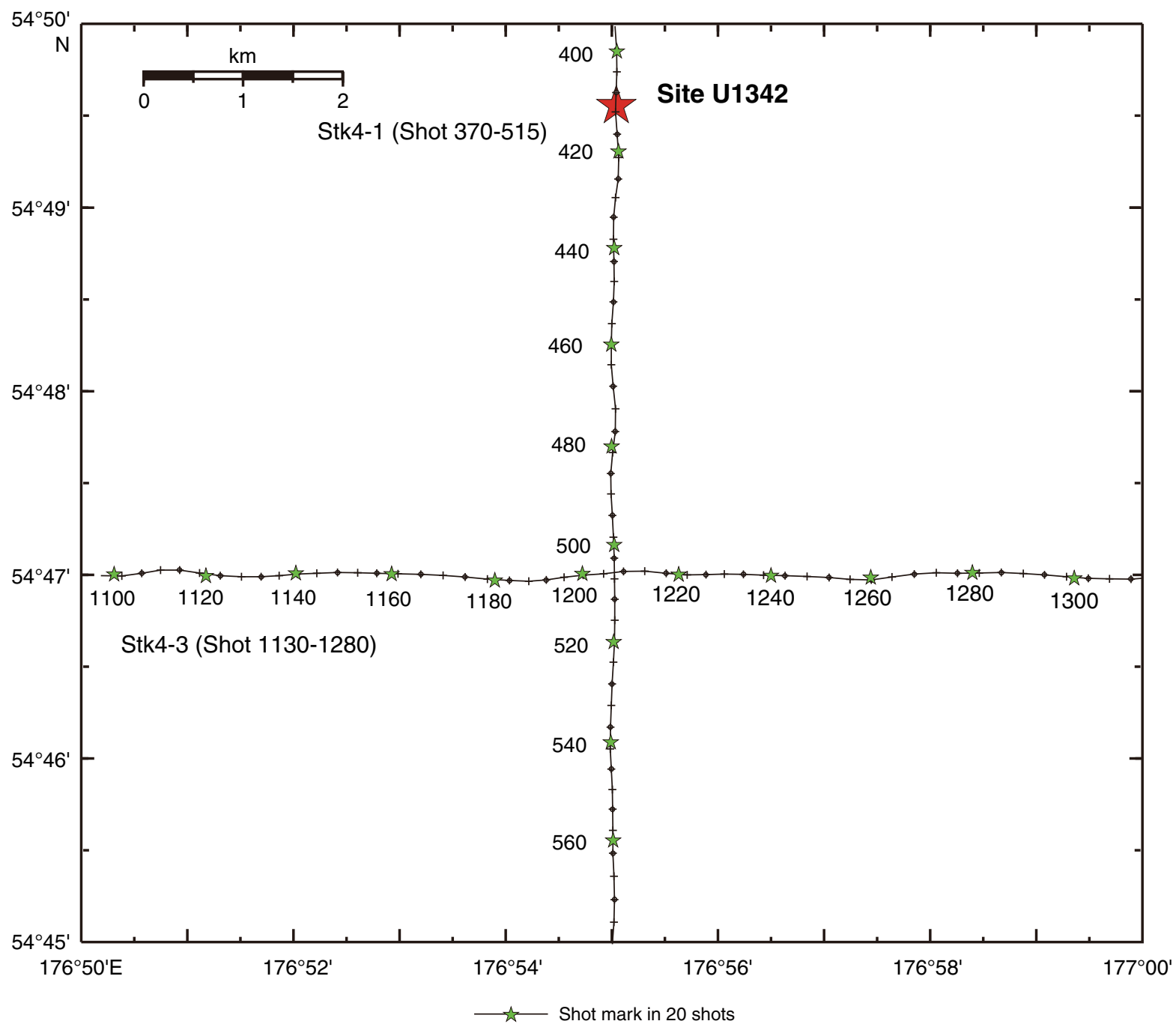


Figure F4. A. Close-up seismic profile of Hakuhou-Maru Cruise KH99-3 Line Stk4-3 (west-east) near Site U1342. Cross point with Line Stk4-1 (north-south) is at Shotpoint 1203. B. Time-depth curve estimated from results of velocity analyses on Lines Stk4-1 and Stk4-3.

A
Shotpoint
1210
1230
1250

0.5

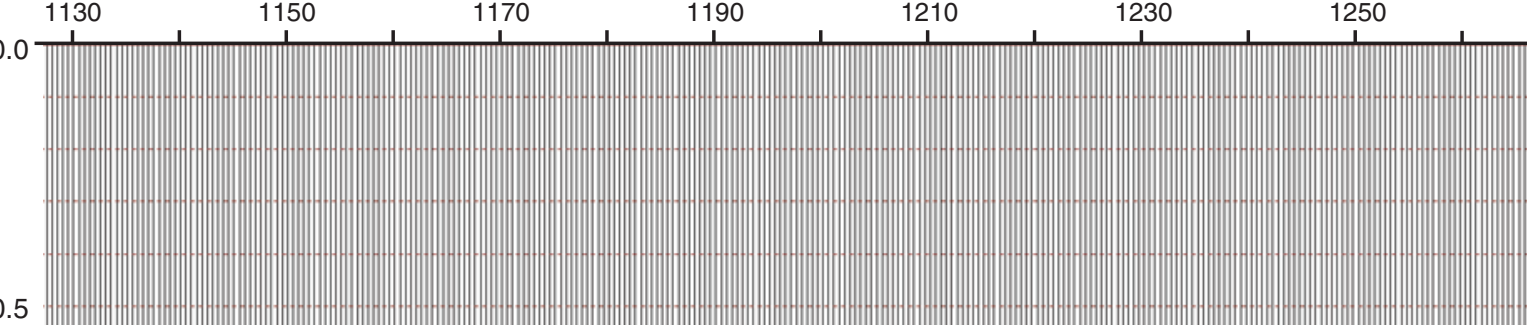

1.5

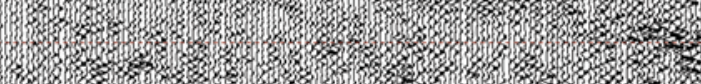

\section{Stk4-1 (N-S)}

cross point
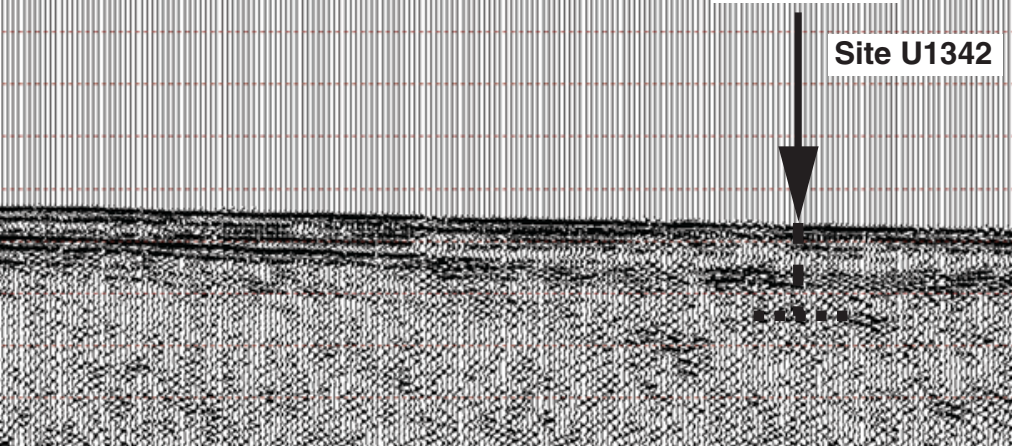

v

V

r.

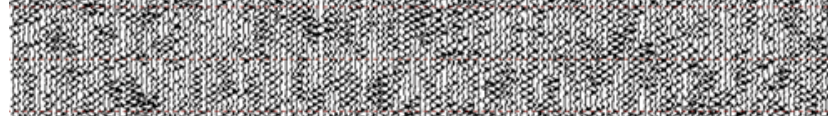

6
B Two-way traveltime bsf (s)

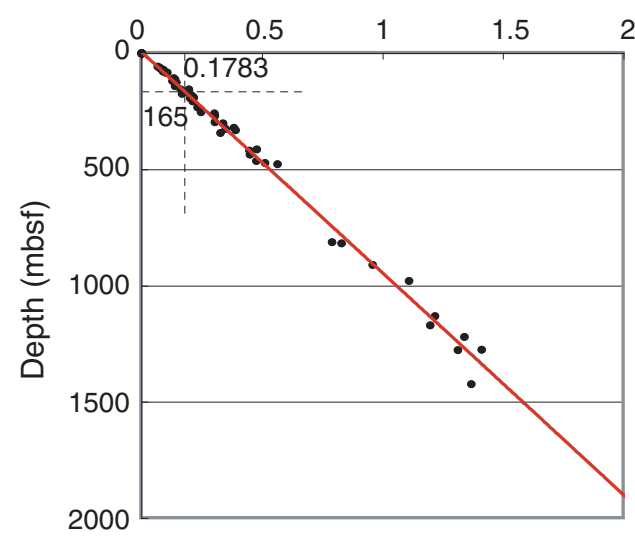


Figure F5. A. Close-up seismic profile of Hakuhou-Maru Cruise KH99-3 Line Stk4-1 (north-south) near Site U1342. Cross point with Line Stk4-3 (west-east) is at Shotpoint 505. B. Time-depth curve estimated from results of velocity analyses on Lines Stk4-1 and Stk4-3.

A

N Shotpoint S

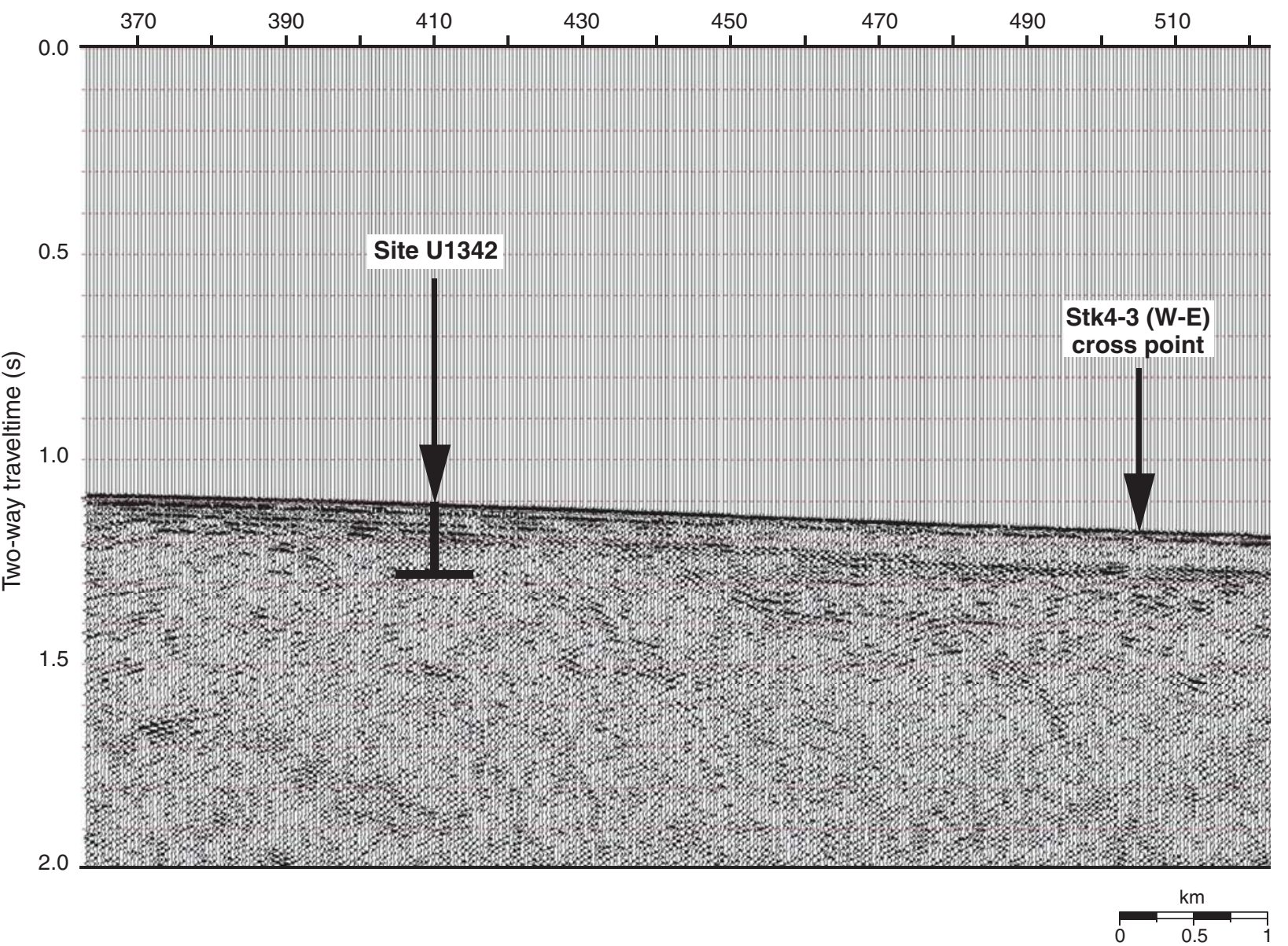

B

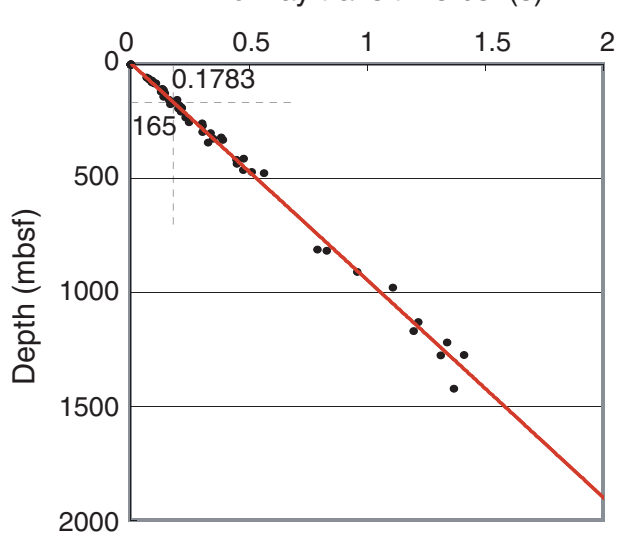


Figure F6. Summary of lithology, structures, accessories, microfossils, and physical properties, Hole U1342A. See legend in Figure F6 in the "Methods" chapter. Soft-sed = soft-sediment, auth = authigenic, calc = calcareous, NGR = natural gamma radiation, GRA = gamma ray attenuation, sed rate $=$ sedimentation rate.
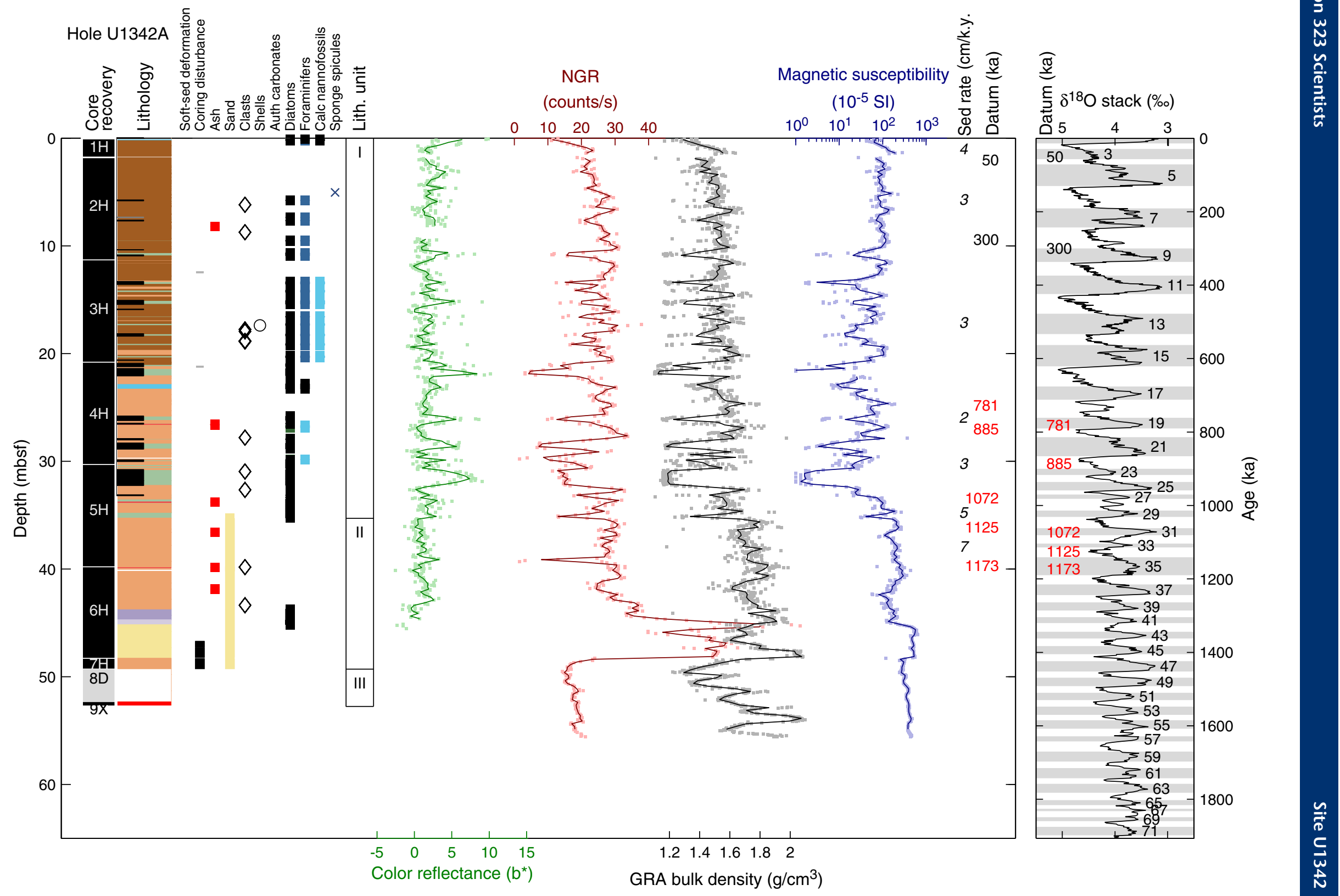
Figure F7. Summary of lithology, structures, accessories, microfossils, and physical properties, Hole U1342C. See legend in Figure F6 in the "Methods" chapter. Soft-sed = soft-sediment, auth = authigenic, calc = calcareous, NGR = natural gamma radiation, GRA = gamma ray attenuation, sed rate $=$ sedimentation rate.

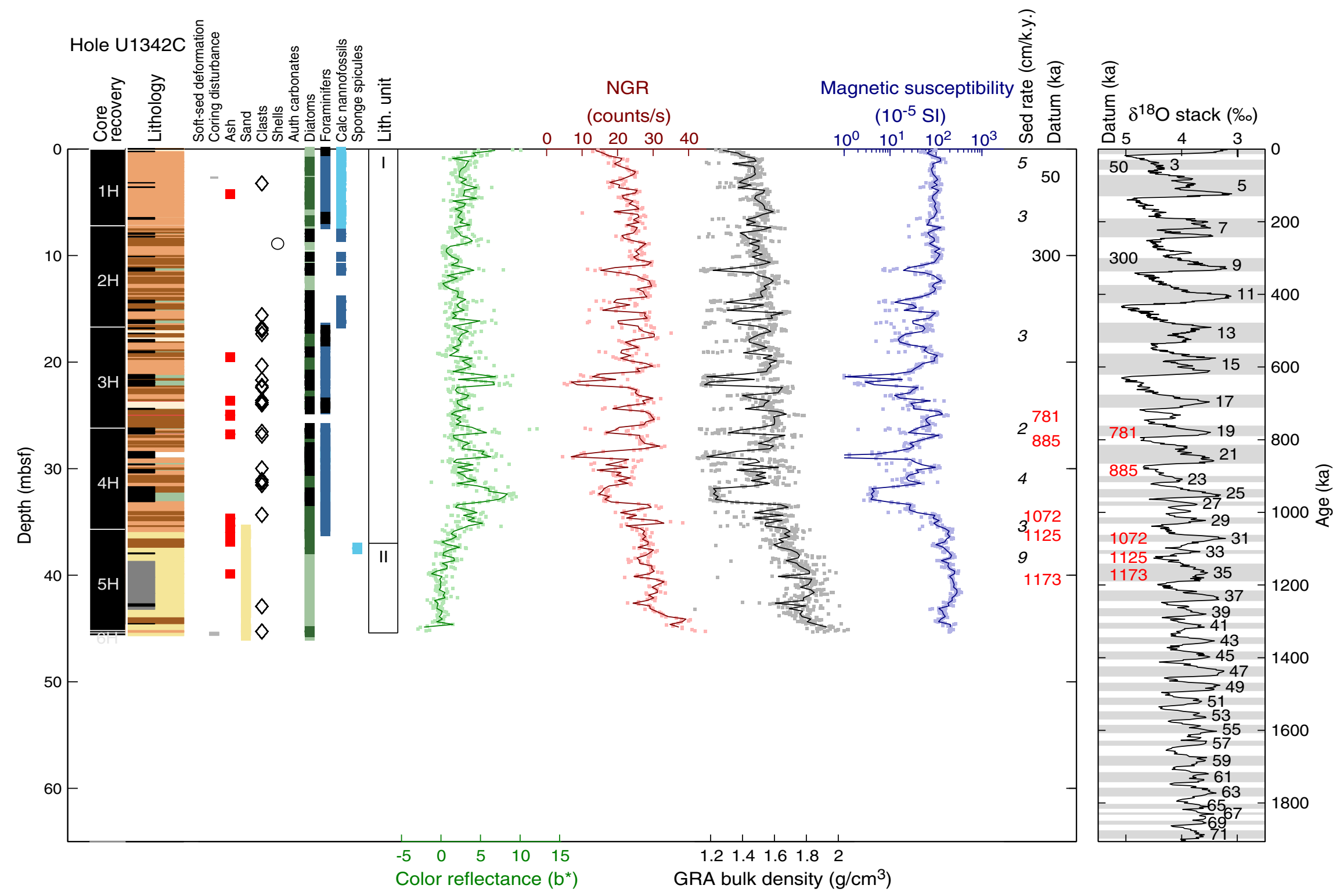


Figure F8. Summary of lithology, structures, accessories, microfossils, and physical properties, Hole U1342D. See legend in Figure F6 in the "Methods" chapter. Soft-sed = soft-sediment, auth = authigenic, calc = calcareous, NGR = natural gamma radiation, GRA = gamma ray attenuation, sed rate $=$ sedimentation rate. A. 0-65 mbsf. (Continued on next page.)

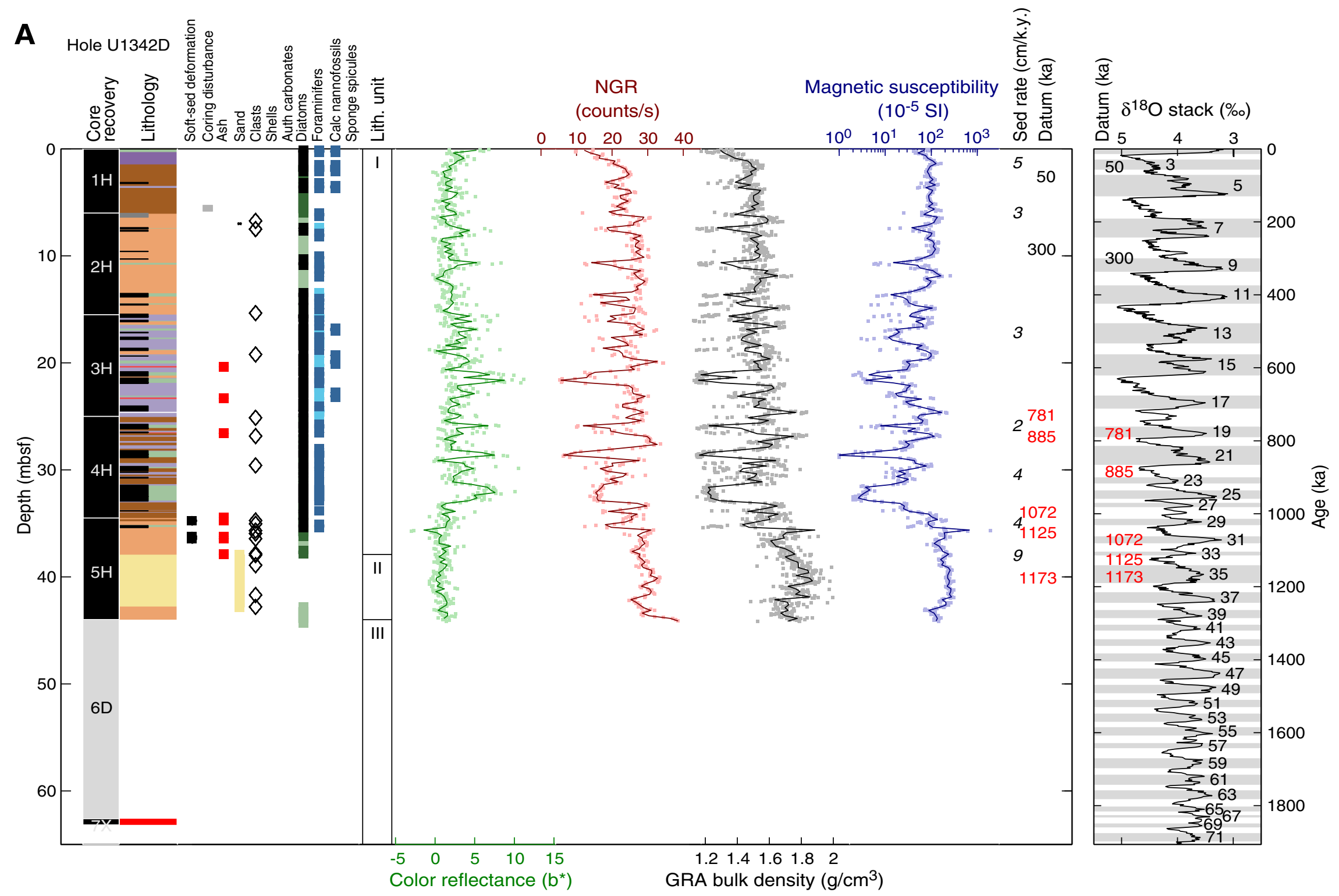




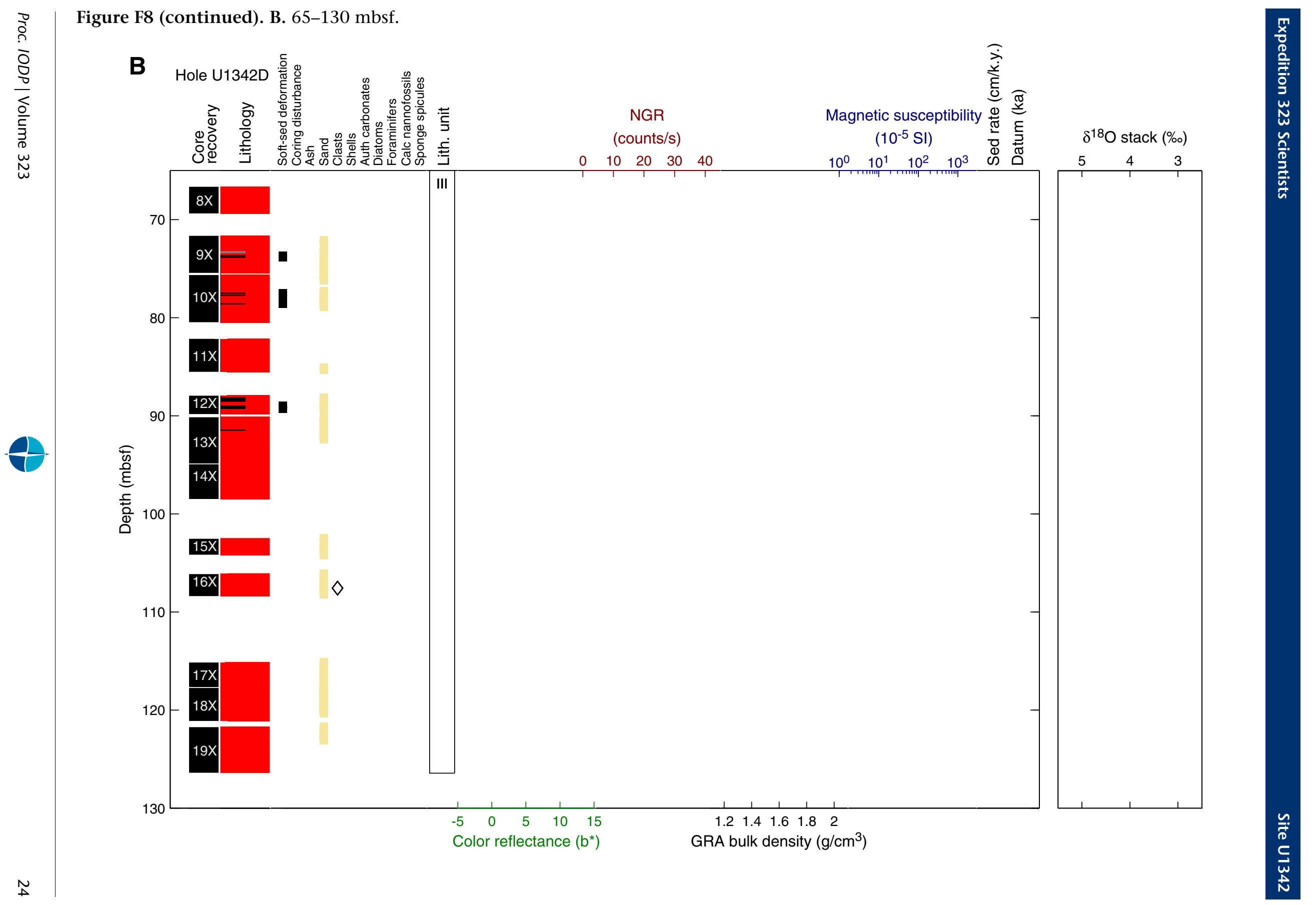


Figure F9. Correlation of laminated sediments, Holes U1342A, U1342C, and U1342D. The lithologic columns are from Figures F6, F7, and F8. Note that the depth of each laminated interval is converted into CCSF-A (m). Age estimates are determined by radiolarians (R), calcareous nannofossils $(\mathrm{C})$, silicoflagellates (S), or paleomagnetism (P). Triangles = lamination depth in Hole U1342A, diamonds = lamination depth in Hole U1342C, circles = lamination depth in Hole U1342D. Green lines connect correlated laminations between holes. Benthic $\delta^{18} \mathrm{O}$ stack is from Lisiecki and Raymo (2005).

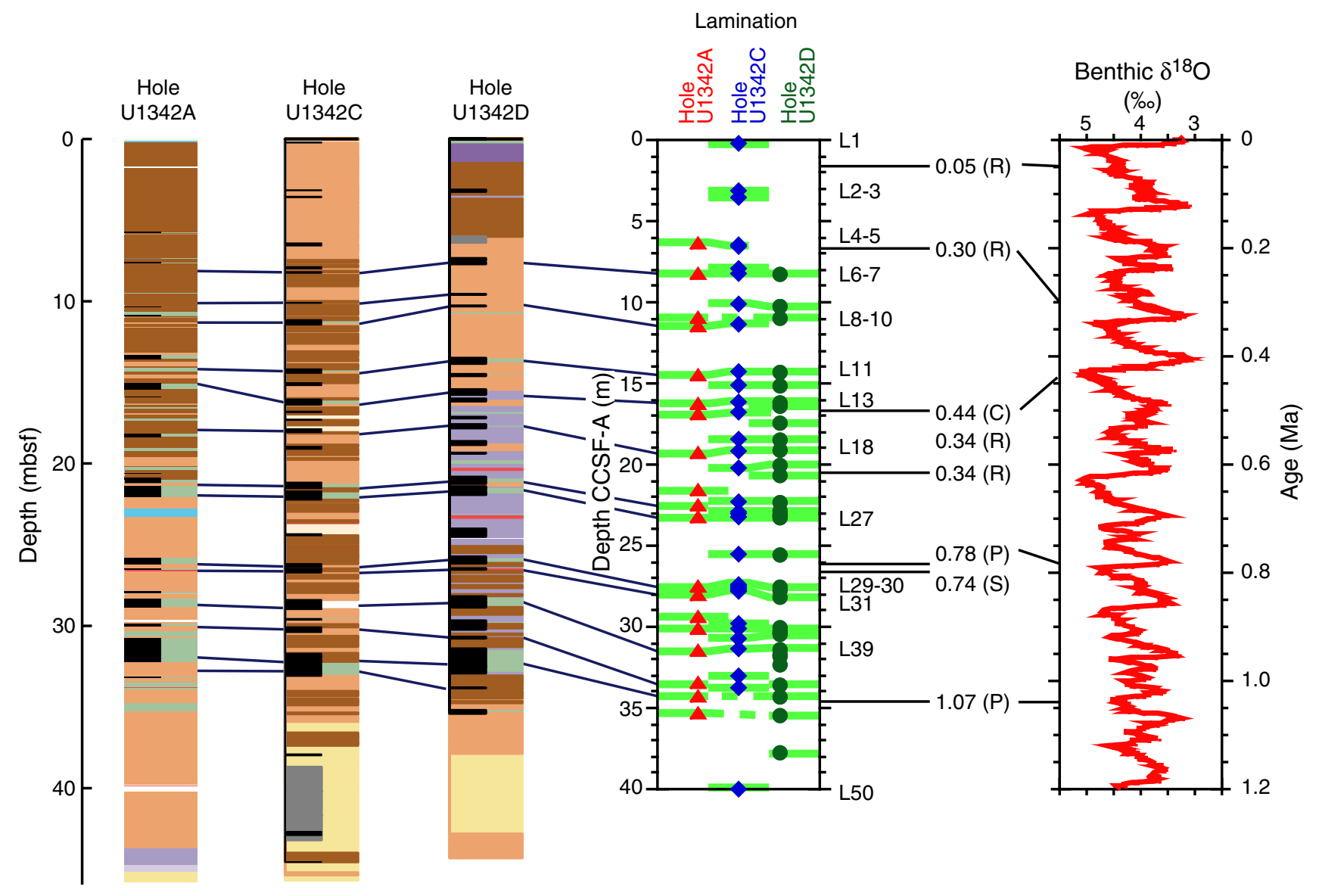


Figure F10. Core photographs of a laminated interval correlated between Holes U1342A, U1342C, and U1342D. A. Bioturbated diatom ooze (interval 323-U1342A-3H-2, 111-123 cm). B. Well-preserved laminated interval (323-U1342C-2H-7, 1-21 cm). C. Laminated interval (323-U1342D-3H-6, 31-43 cm).

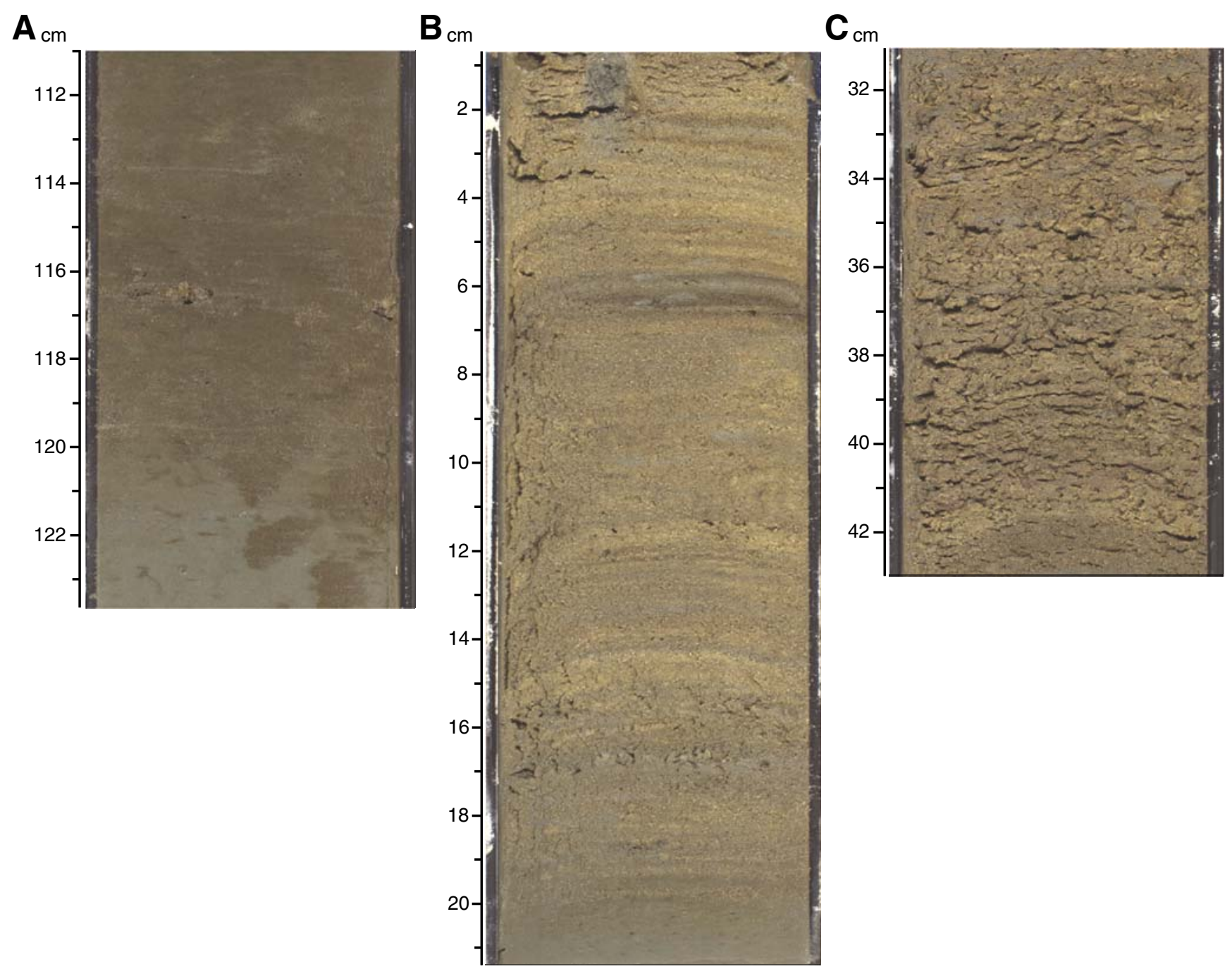


Figure F11. Sandy lithology in Unit II. A. Line-scan image (interval 323-U1342A-5H-4, 43-64 cm). B. Photomicrograph of grain mount from Section 323-U1342A-6H-6, $60 \mathrm{~cm}$, under plane-polarized (above) and crosspolarized (below) light. The glauconite is the green grain in the center of the field of view.
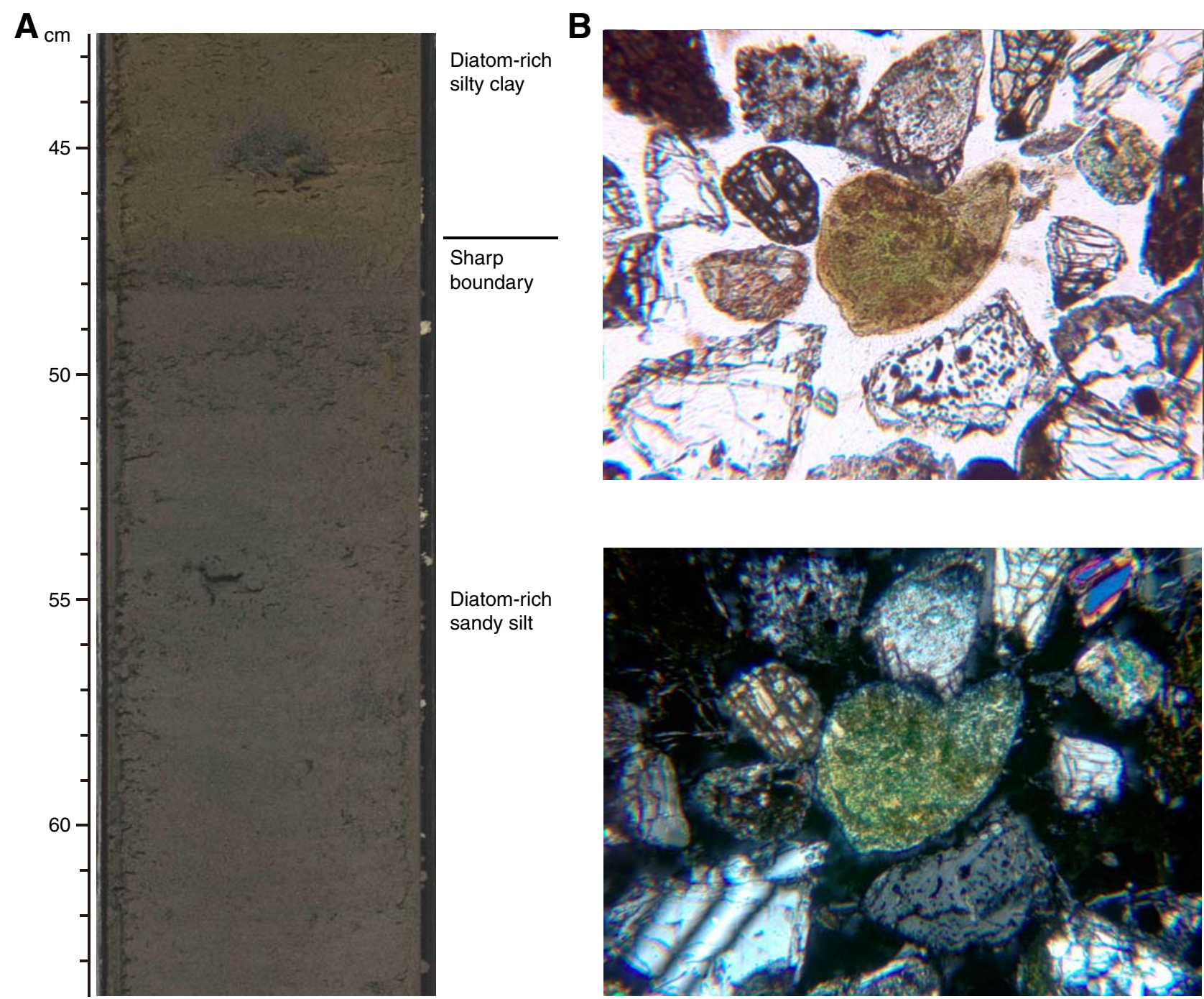

Diatom-rich

sandy silt

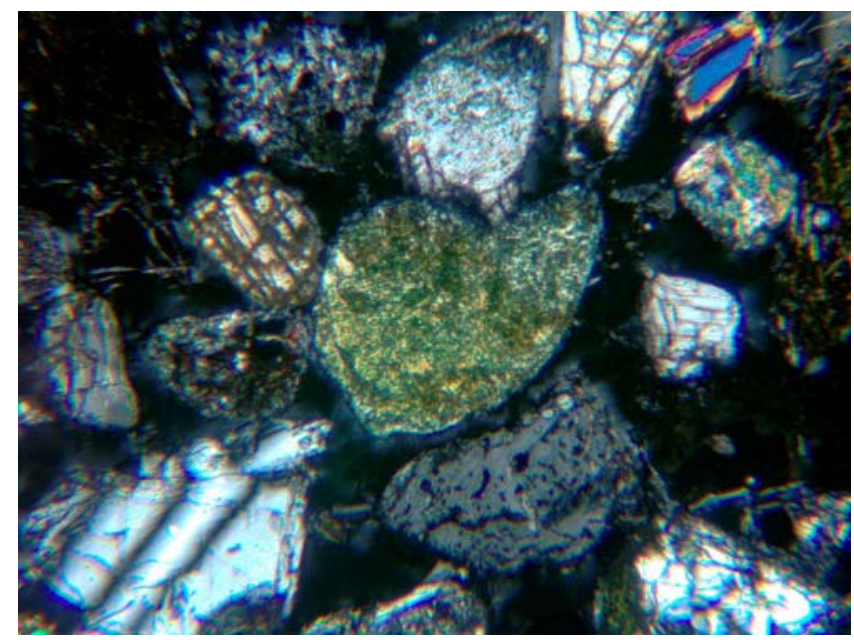


Figure F12. Igneous rock and volcanic sandstone in Unit III. A. Line-scan image of interval 323-U1342D-7X-1, 21-31. B. Thin section photomicrograph of igneous rock from Section 323-U1342D-7X-1. C. Line-scan image of interval 323-U1342D-8X-1, 63-74 cm. D. Thin section photomicrograph of volcanic sandstone from Section 323-U1342D-8X-1.

A

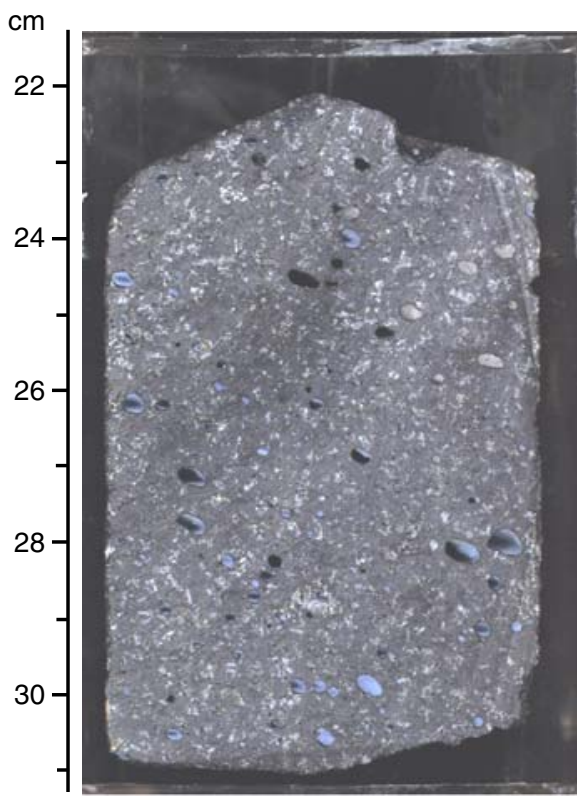

$\mathbf{C}_{\mathrm{cm}}$

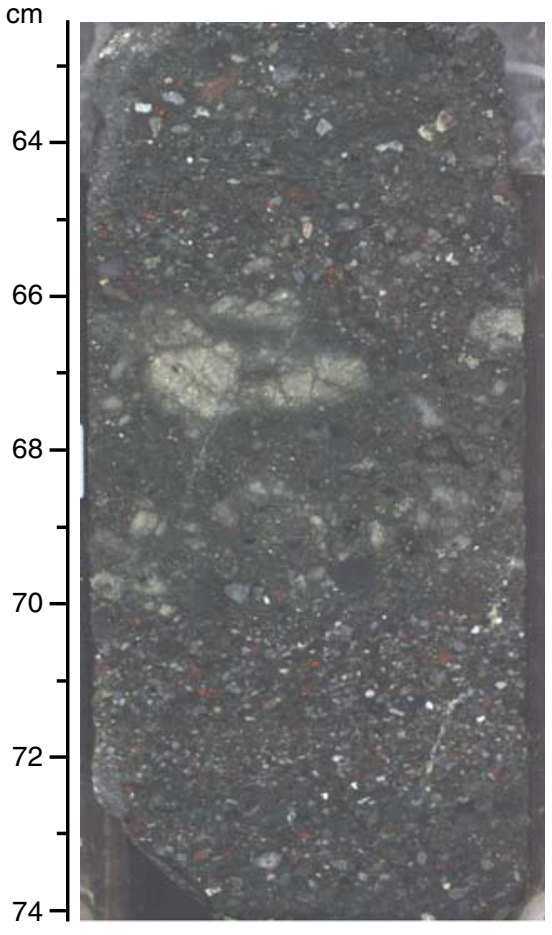

B

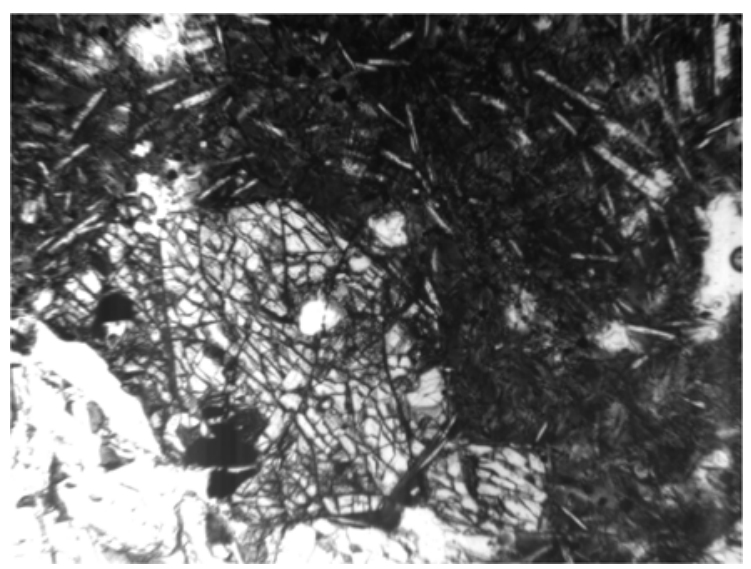

D

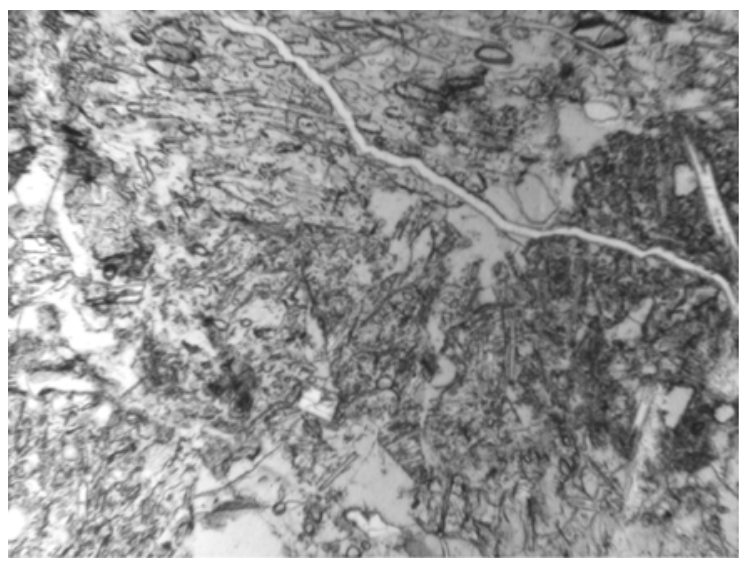


Figure F13. Core photographs of examples of (A) soft-sediment deformation in interval 323-U1342D-12X-2, $49-60 \mathrm{~cm}$, and (B) a normal fault in interval 323-U1342D-12X-2, 5-26 cm.
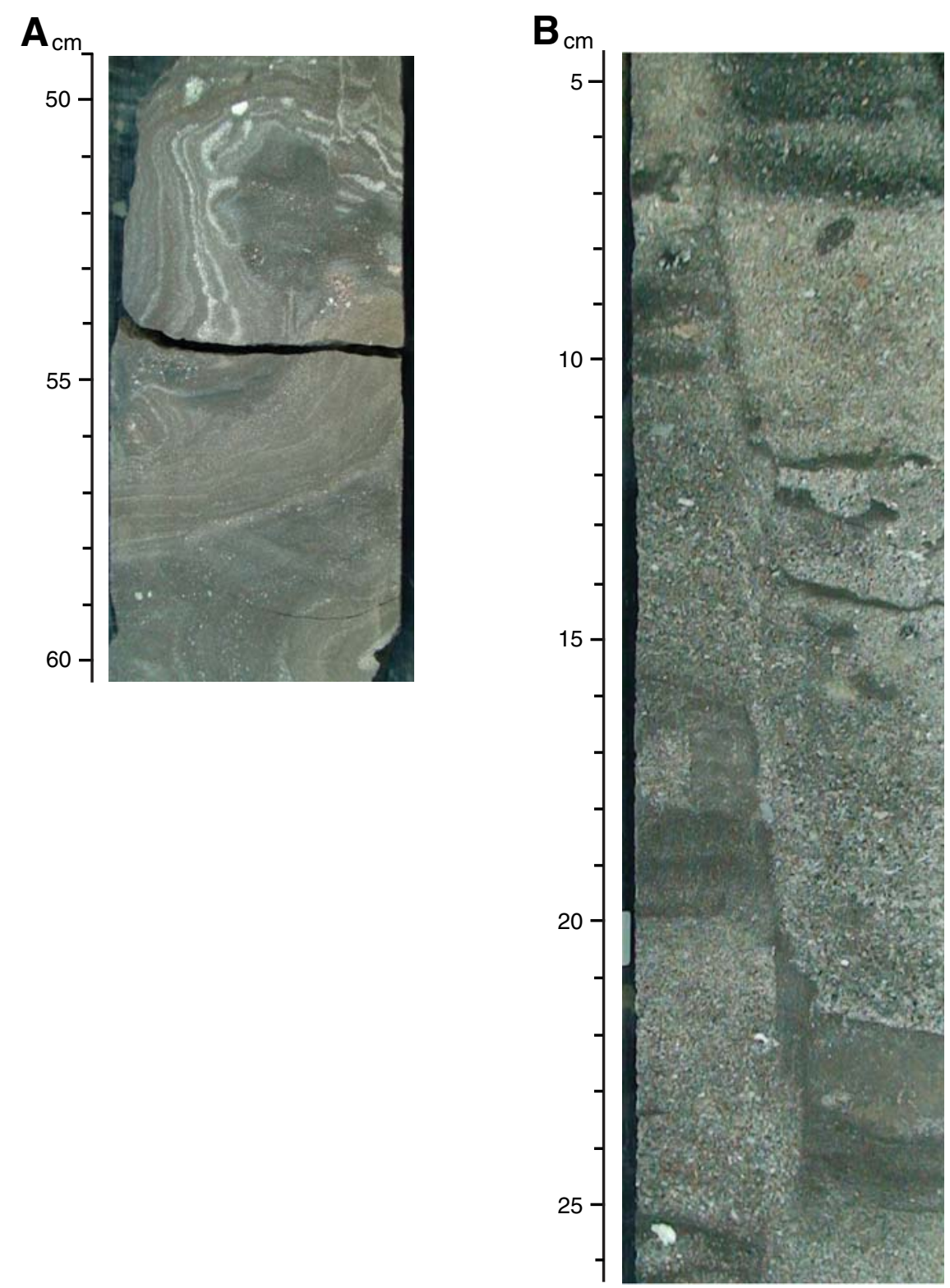
Figure F14. Comparison of laminated interval locations and color reflectance parameters $\mathrm{L}^{*}$ and $\mathrm{b}^{*}$, Hole U1342A. Age estimates are determined by radiolarians $(\mathrm{R})$, calcareous nannofossils $(\mathrm{C})$, silicoflagellates $(\mathrm{S})$, or paleomagnetism $(\mathrm{P})$. Calc $=$ calcareous. Gray triangles indicate range of biostratigraphic error.

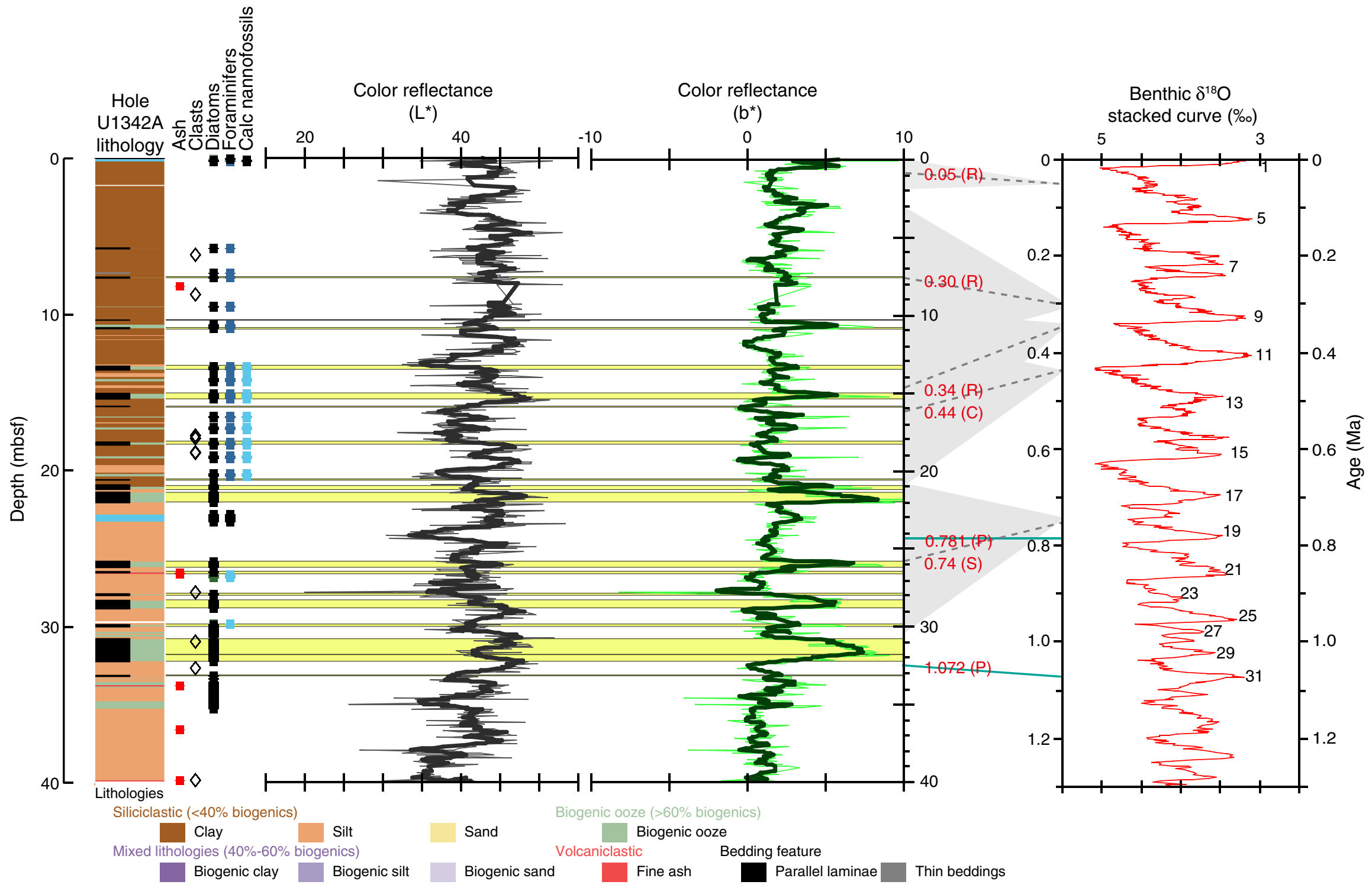


Figure F15. Age-depth plot for Site U1342 showing biostratigraphic datums based on radiolarians, diatoms, calcareous nannofossils, and silicoflagellates.

Age (Ma)

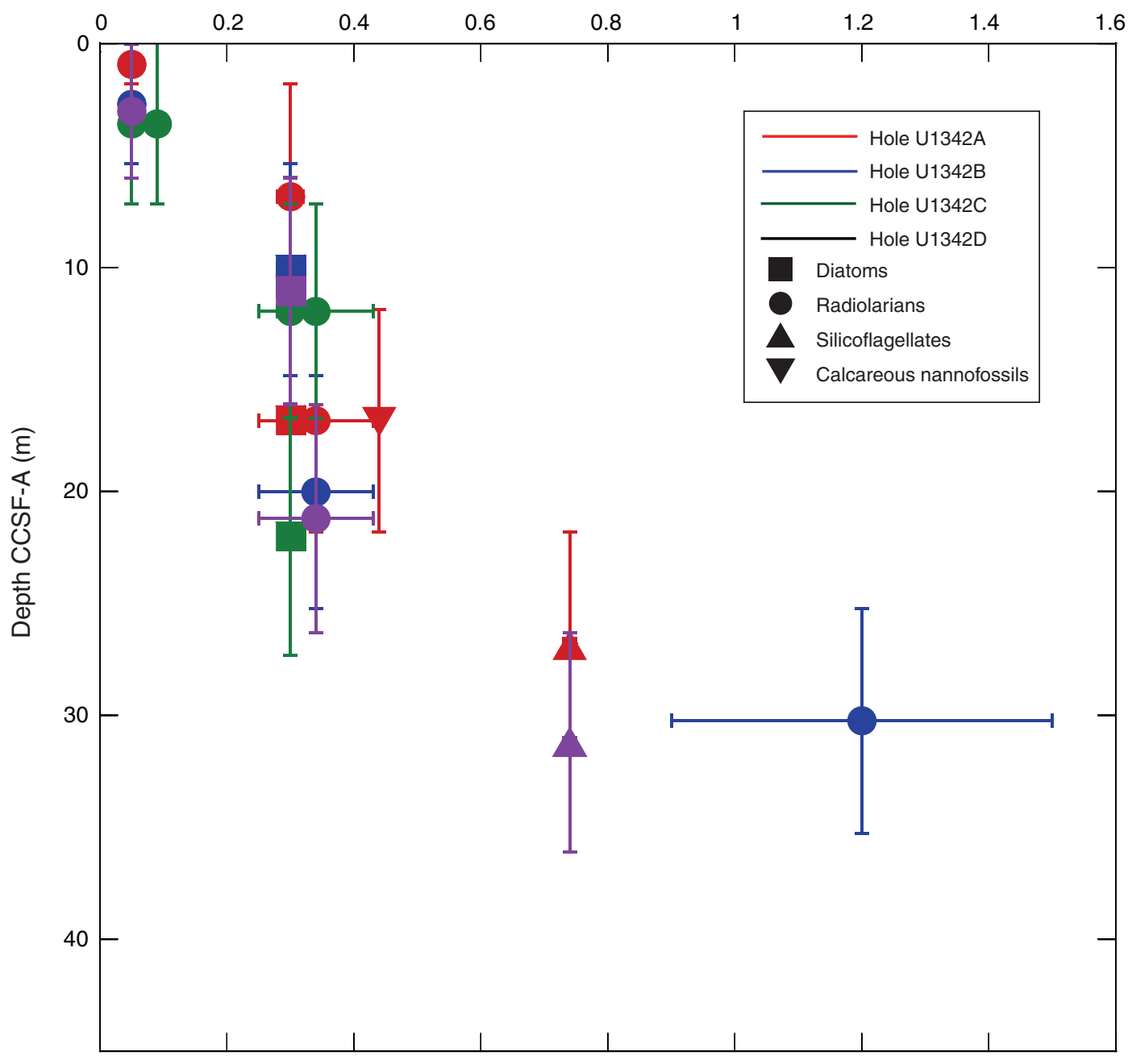


Figure F16. Planktonic foraminifer and calcareous nannofossil abundances, along with percentages of calcium carbonate and heavily silicified diatoms (Coscinodiscus marginatus and Stephanopyxis horridus). $\mathrm{B}=\mathrm{barren}, \mathrm{P}=$ present, $\mathrm{R}=$ rare, $\mathrm{F}=$ few, $\mathrm{A}=$ abundant, $\mathrm{D}=$ dominant.

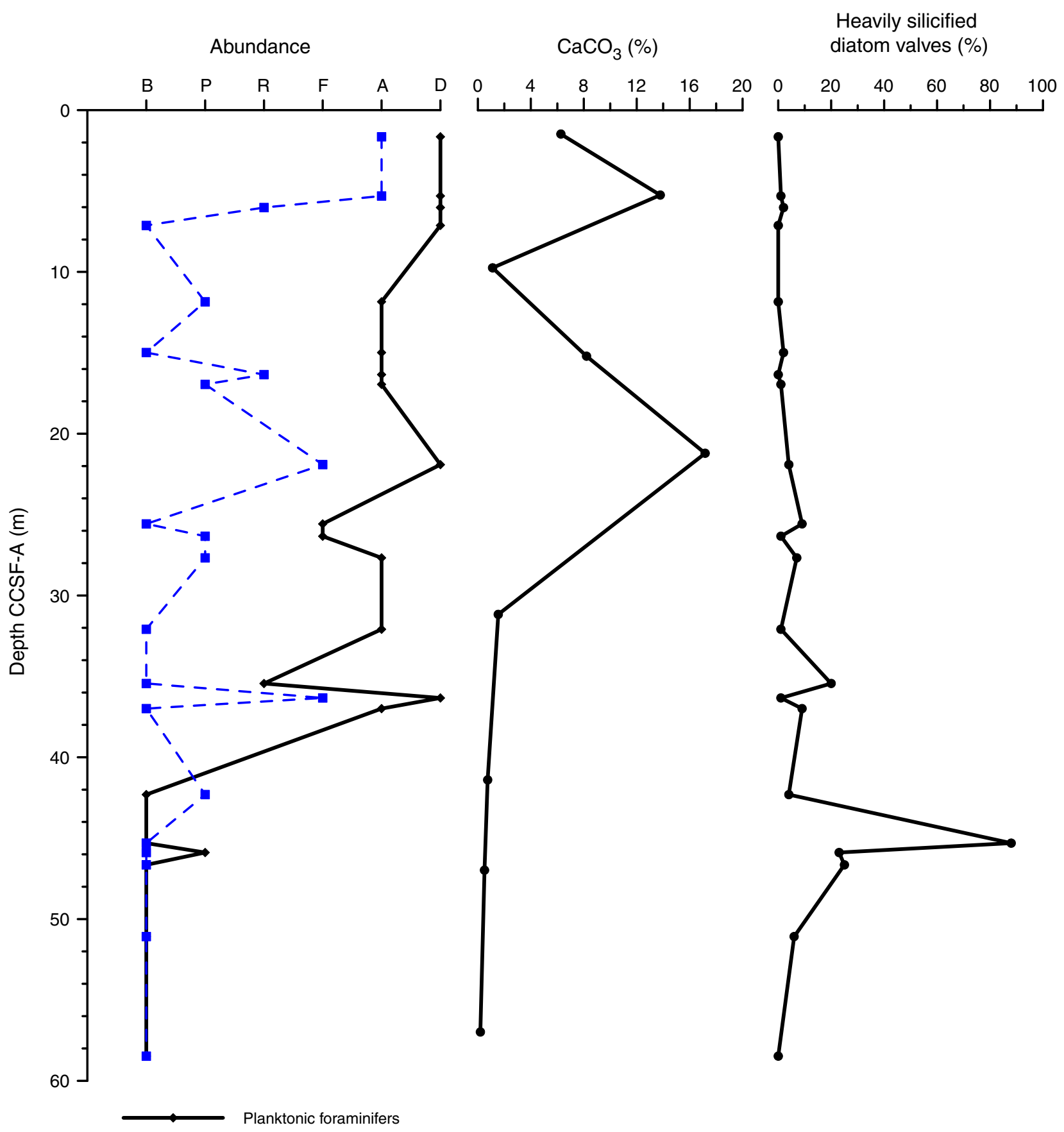


Figure F17. Abundances of sea ice diatoms, sea ice dinoflagellates, planktonic foraminifer species Neogloboquadrina pachyderma (sinistral), and subpolar species Neogloboquadrina pachyderma (dextral), Globigerina bulloides, and Globigerina umbilicata. $\mathrm{B}=$ barren, $\mathrm{P}=$ present, $\mathrm{R}=$ rare, $\mathrm{F}=\mathrm{few}, \mathrm{A}=$ abundant, $\mathrm{D}=$ dominant. Sea ice diatom species considered include Thalassiosira antarctica spores, Dentonula confervacea, Fragilariopsis cylindrus, and Porosira glacialis.

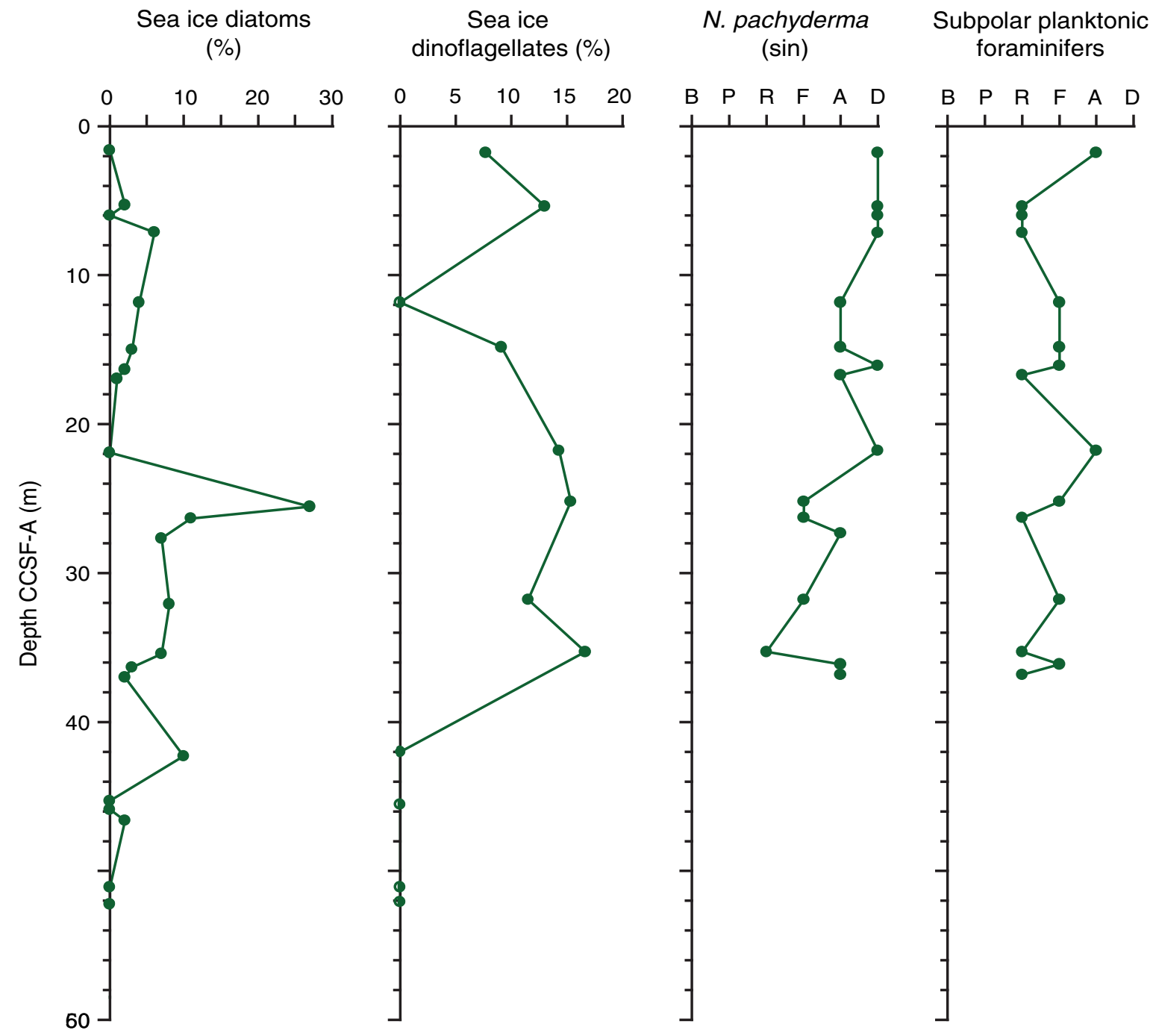


Figure F18. Composite record of gamma ray attenuation (GRA) bulk density and the semiquantitative ratio between Bulimina and Uvigerina species.

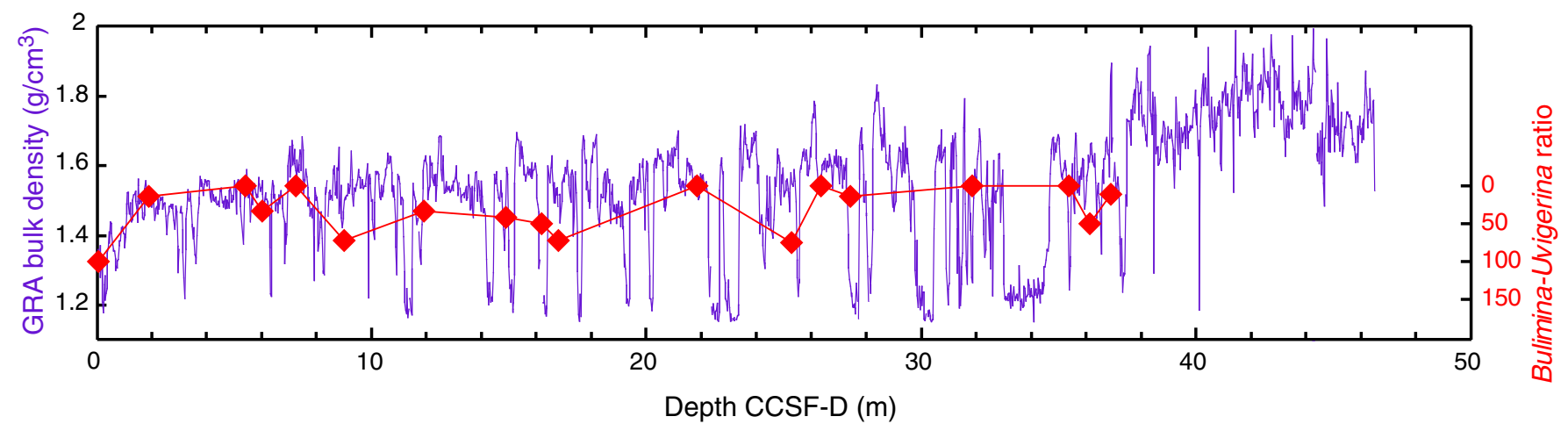


Figure F19. Inclination and intensity of remanent magnetization after $20 \mathrm{mT}$ AF demagnetization (Int $20 \mathrm{mT}$ ), Holes U1342A, U1342C, and U1342D. Intensity data are plotted with STMSL magnetic susceptibility data.

Hole U1342A

Inclination ( $\left(^{\circ}\right) \quad \operatorname{Int}_{20 \mathrm{mT}}(\mathrm{A} / \mathrm{m})$

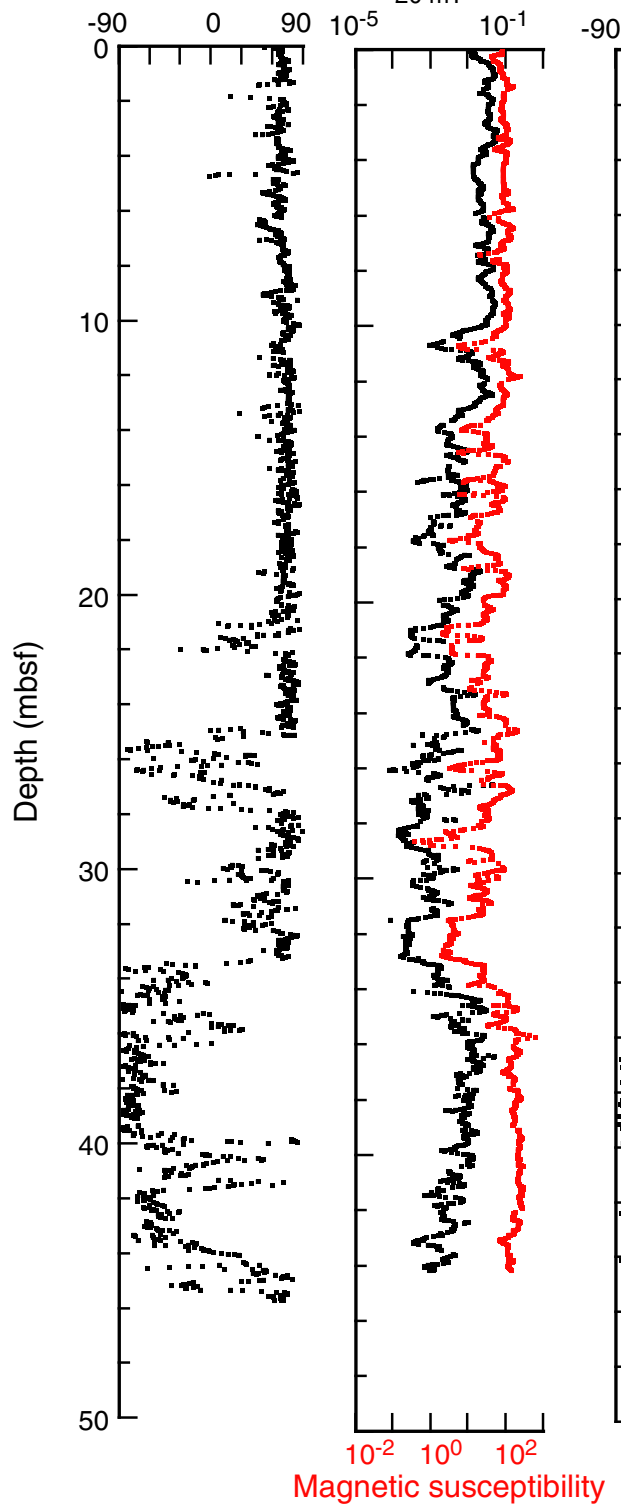

$\left(10^{-5} \mathrm{SI}\right)$
Hole U1342C

Hole U1342D

Inclination $\left(^{\circ}\right) \quad \operatorname{lnt}_{20 \mathrm{mT}}(\mathrm{A} / \mathrm{m}) \quad$ Inclination $\left(^{\circ}\right) \quad \operatorname{lnt}_{20 \mathrm{mT}}(\mathrm{A} / \mathrm{m})$

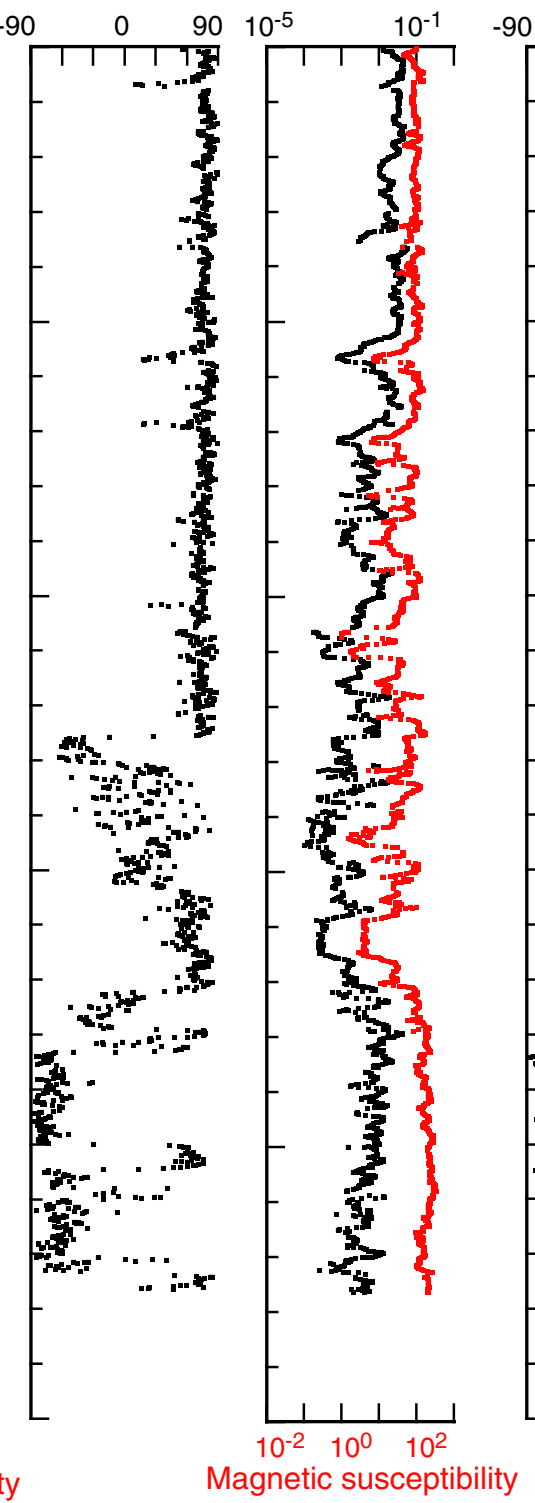

$\left(10^{-5} \mathrm{SI}\right)$

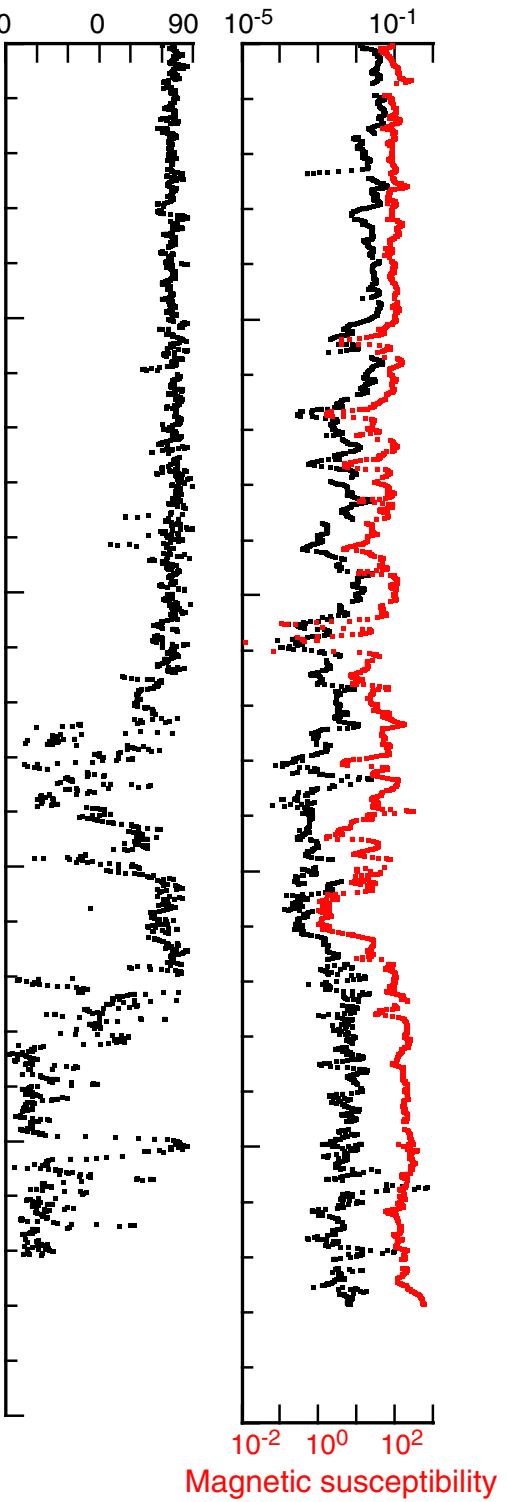

$\left(10^{-5} \mathrm{SI}\right)$ 
Figure F20. Inclination data (dots) and 60 point (corresponding to $\sim 0.5 \mathrm{~m}$ ) averaged inclination values (solid line), Holes U1342A, U1342C, and U1342D. Tentative polarity zonation (black = normal polarity, white = reversed polarity, and gray = uncertain polarity) and presumable correlation with reported geomagnetic excursions (names shown above the correlation lines) and polarity chrons are also shown.
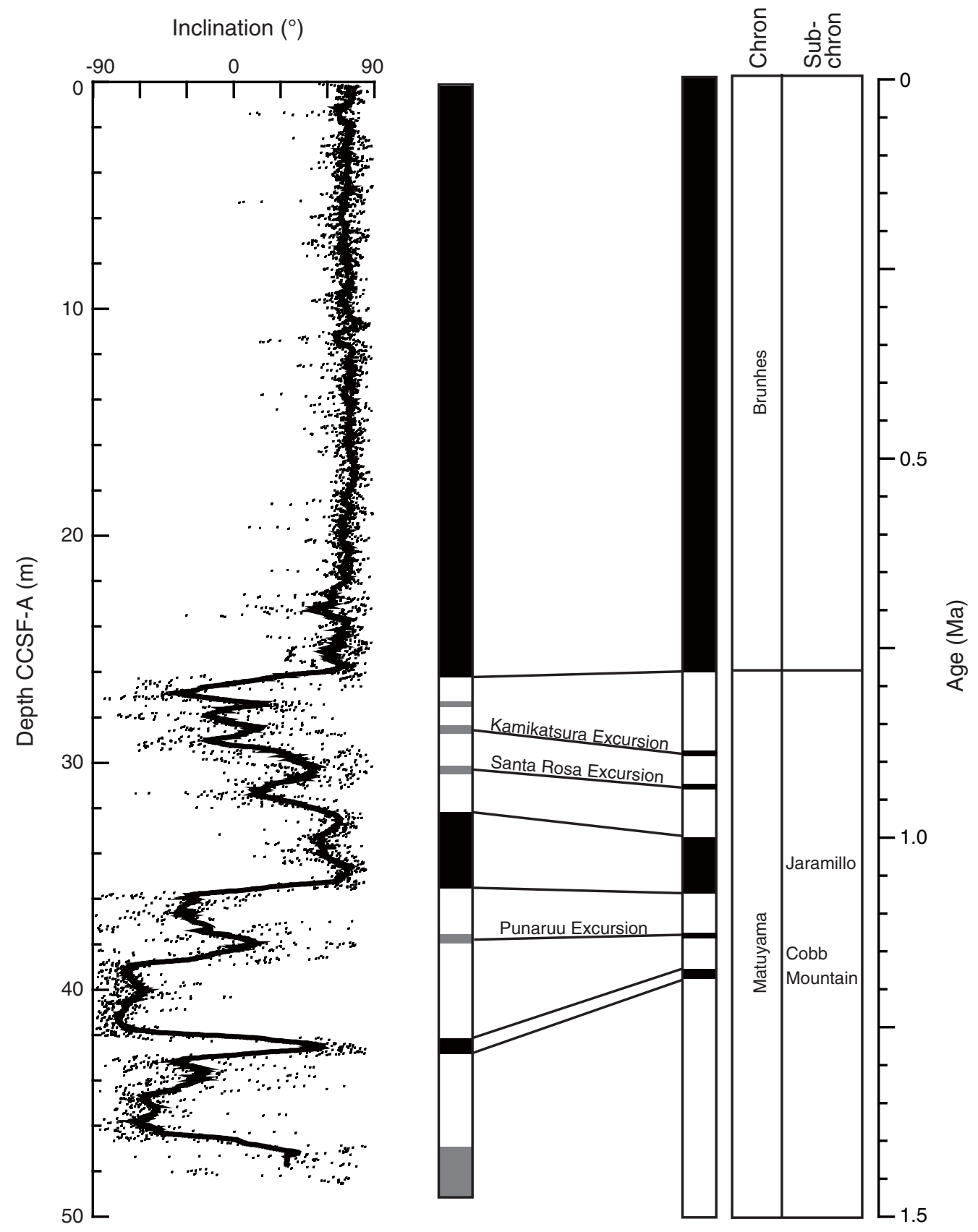
Figure F21. Magnetic susceptibility and relative paleointensity ( Int $_{20 \mathrm{mT}} /$ Magnetic susceptibility), Site U1341. The Brunhes/Matuyama magnetic polarity boundary is at $90 \mathrm{~m}$ CCSF-A. Numbered features = best guesses for how each feature relates to a marine isotope stage.

Site U1341

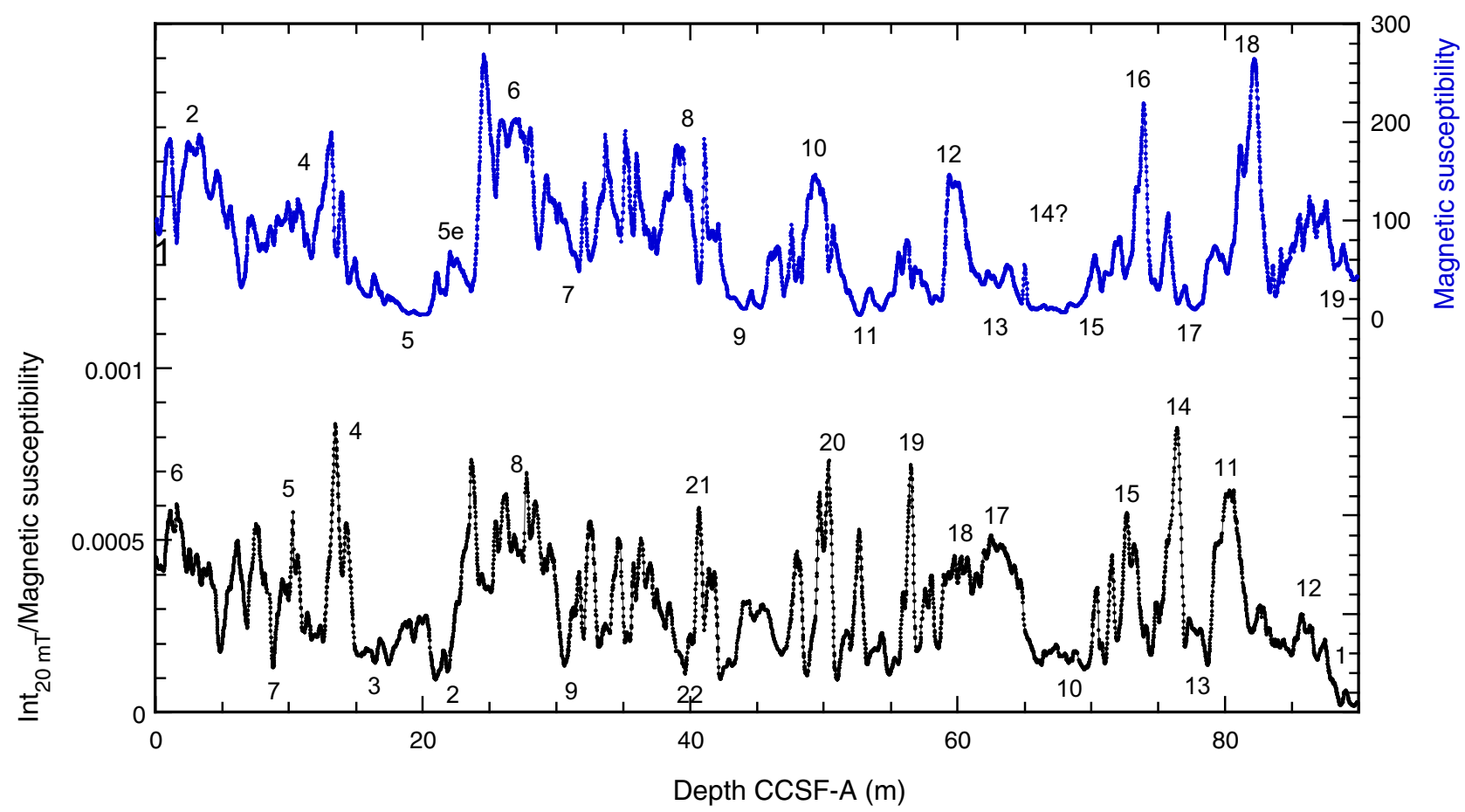


Figure F22. Magnetic susceptibility and relative paleointensity ( $\operatorname{Int}_{20 \mathrm{mT}} /$ Magnetic susceptibility), Hole U1342A. The Brunhes/Matuyama (B/M) magnetic polarity boundary is at 25.25 mbsf. Numbered features = best guesses for how each feature relates to a marine isotope stage (MIS). These MIS estimates are the basis of the age assignments given in Figure F23.

Hole U1342A

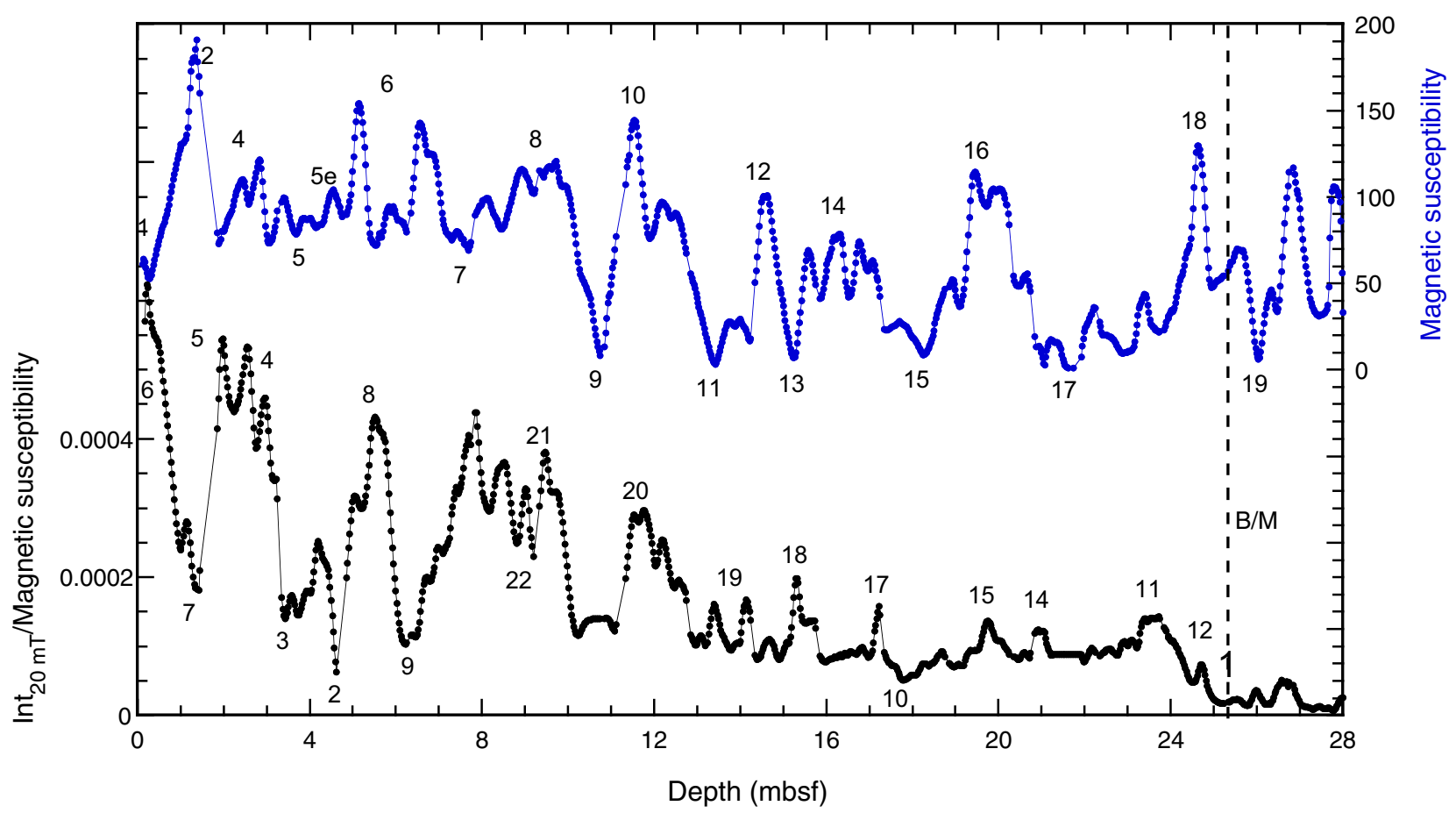


Figure F23. Age-depth plot for Hole U1342A based on paleomagnetic chronostratigraphic estimates. Solid squares = age correlations based on polarity transitions and geomagnetic excursions listed in Table T11, open squares = preliminary paleointensity estimate records shown in Figure F22.

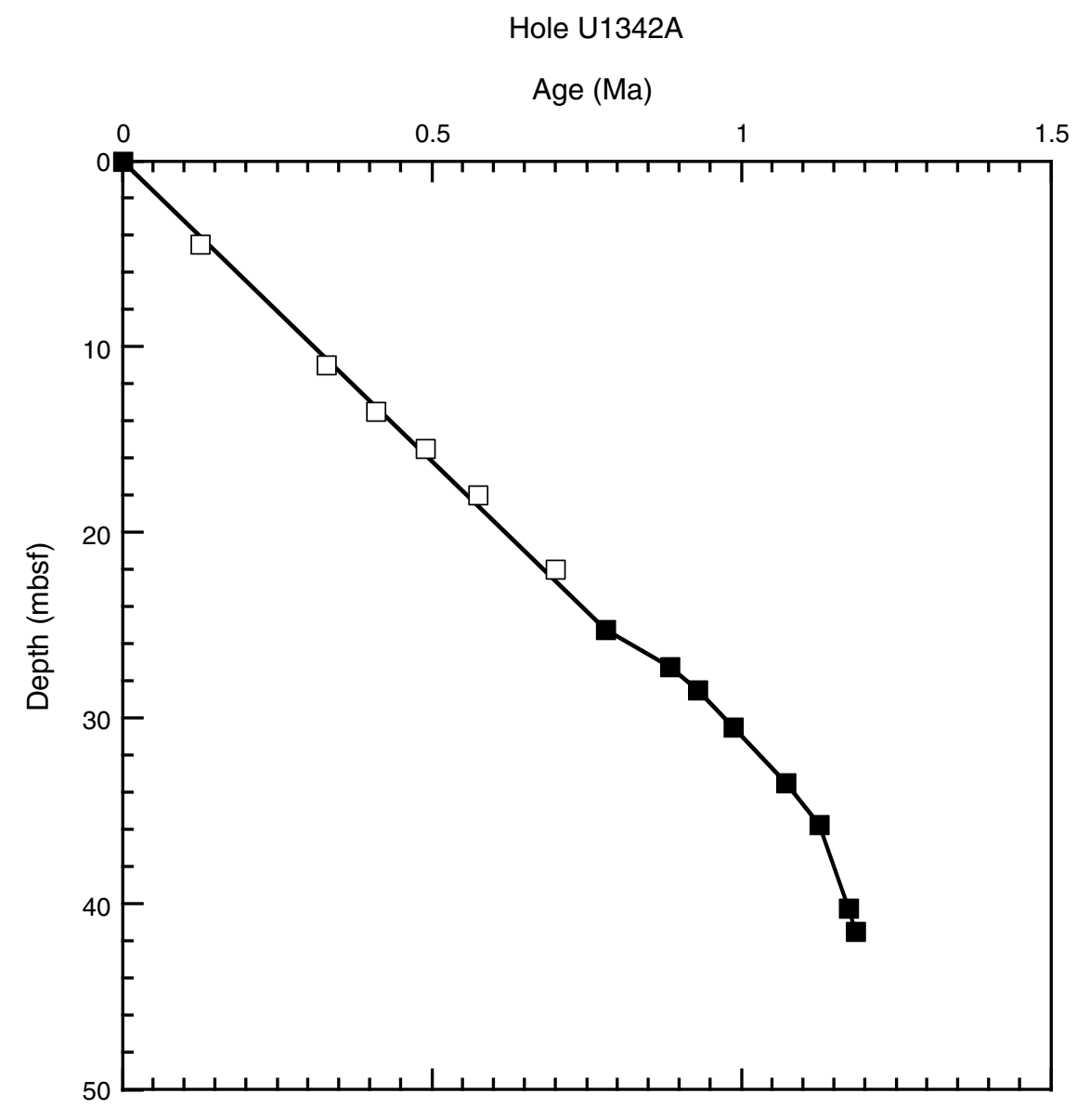


Figure F24. Rock magnetic summary for Hole U1342A showing magnetic susceptibility and remanent magnetization after $20 \mathrm{mT}$ AF demagnetization ( $\mathrm{Int}_{20 \mathrm{mT}}$ ). Note the discrete intervals where both magnetic parameters undergo more than order-of-magnitude decreases.

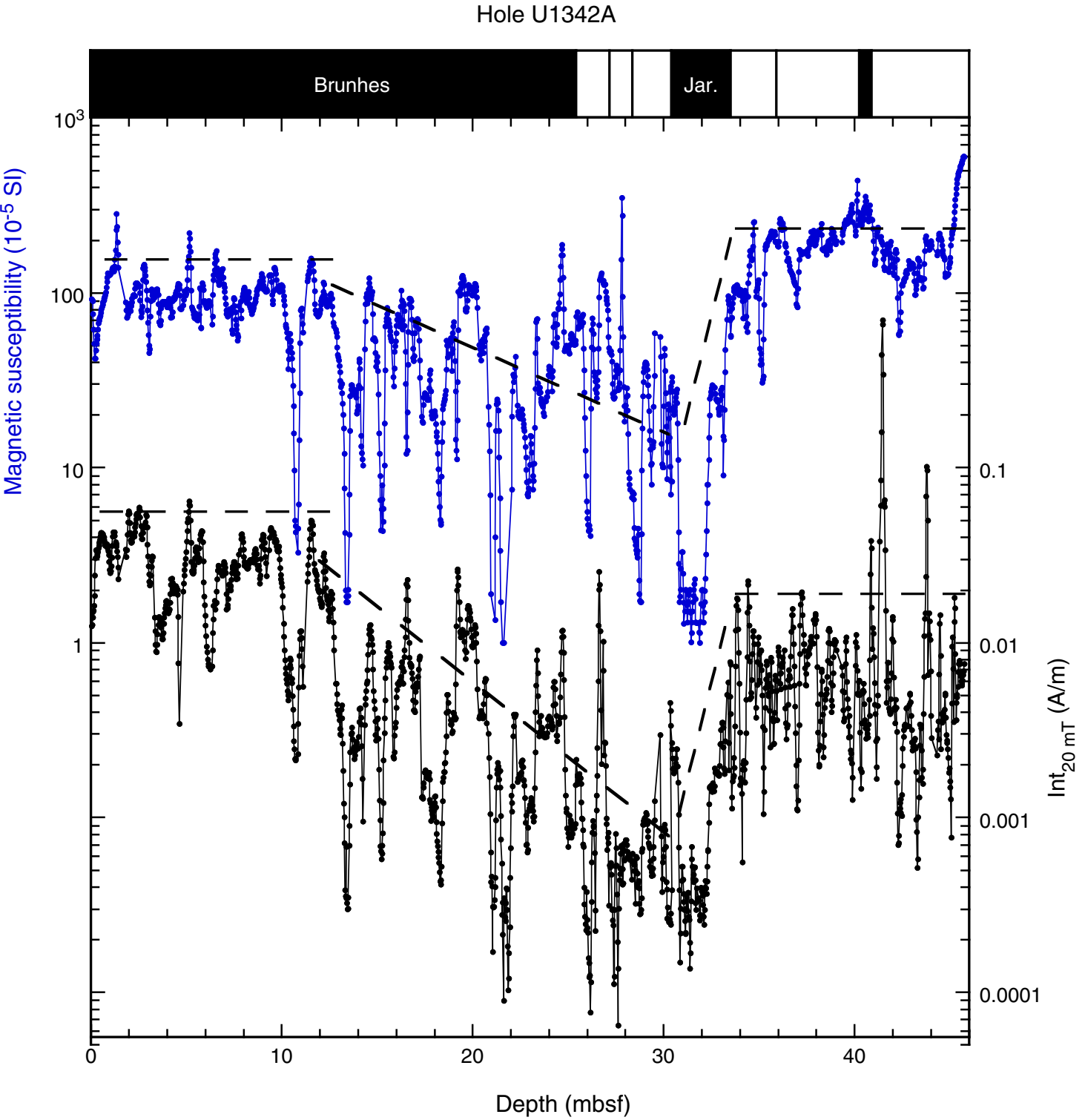


Figure F25. Dissolved chemical concentrations, Holes U1342A and U1342B. A. Dissolved inorganic carbon (DIC). B. pH. C. Alkalinity. D. Sulfate. E. Methane. F. Chloride. G. Phosphate. H. Ammonium.
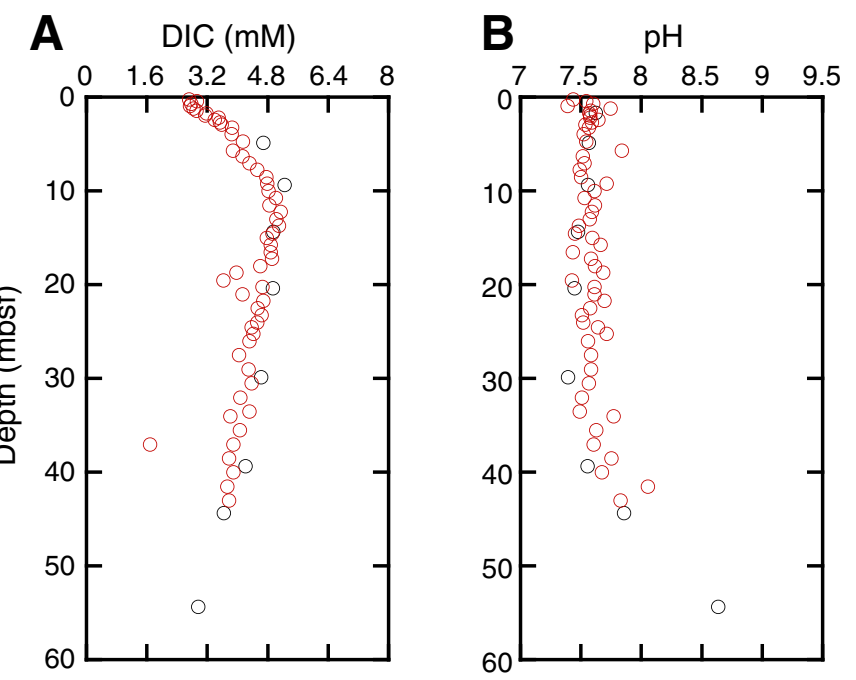

C Alkalinity (mM)

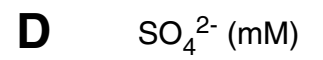

E
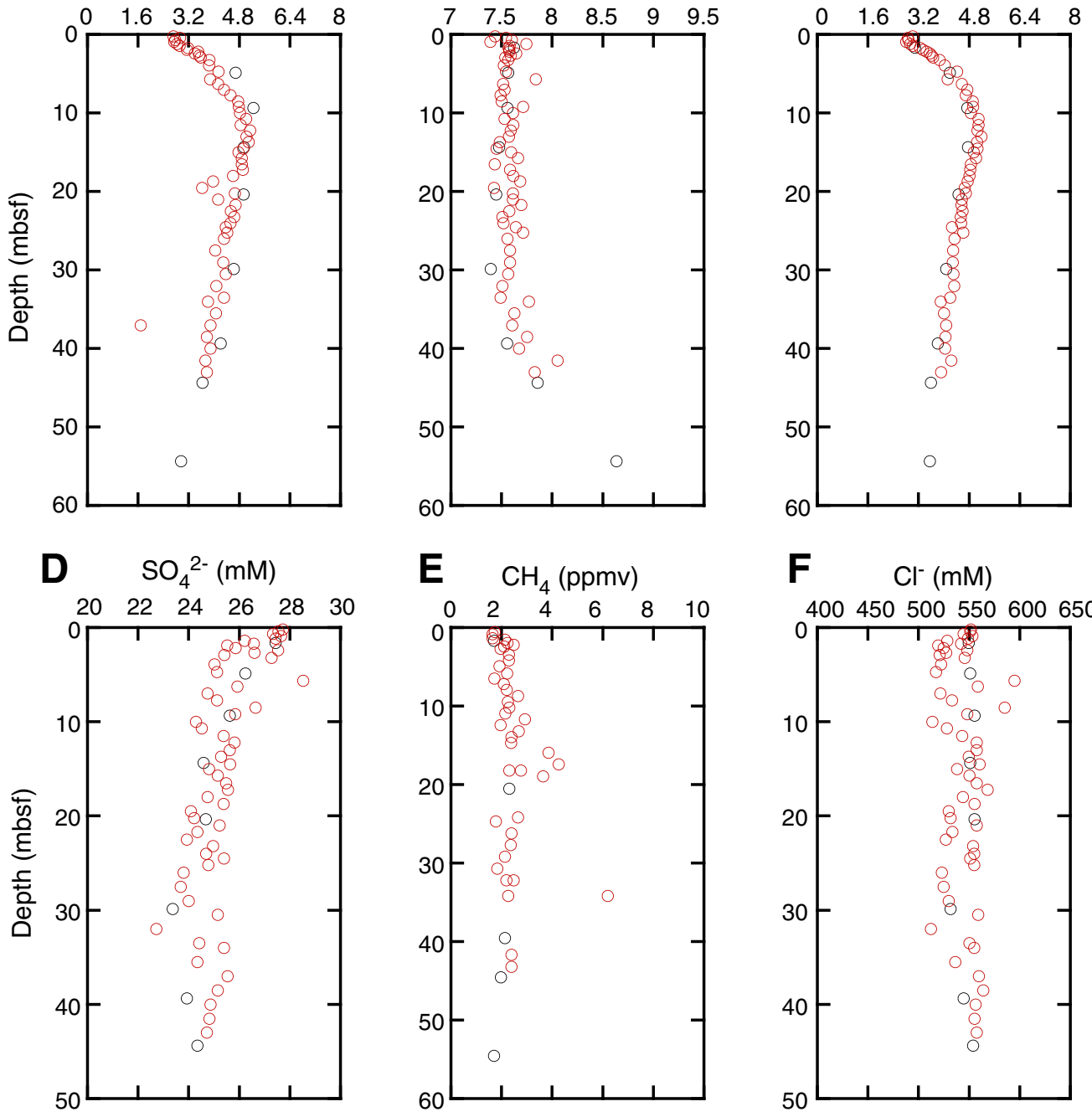

\section{$\mathbf{F} \quad \mathrm{Cl}^{-}(\mathrm{mM})$}
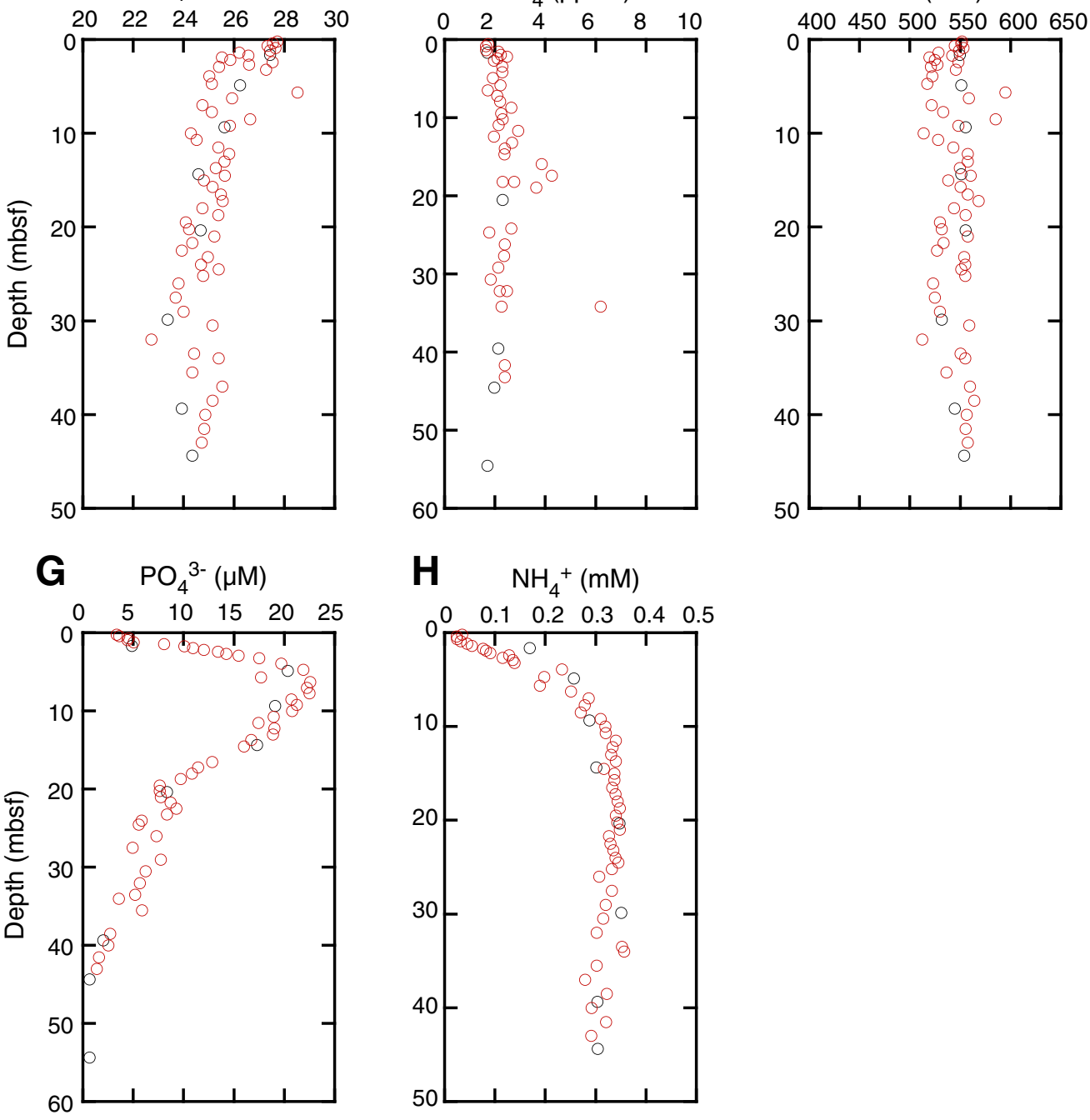

\section{H $\quad \mathrm{NH}_{4}^{+}(\mathrm{mM})$}

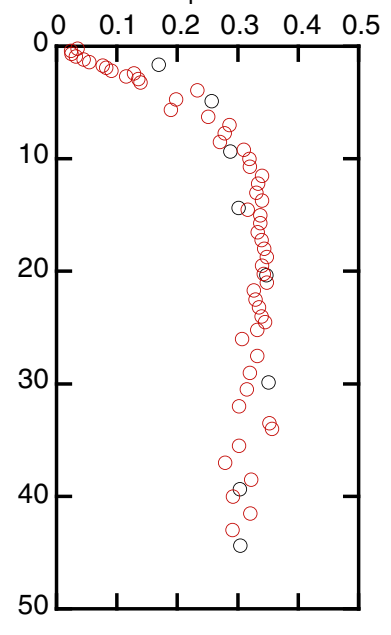

○ Hole U1342A $\bigcirc$ Hole U1342B 
Figure F26. Dissolved chemical concentrations, Holes U1342A and U1342B. A. Calcium. B. Magnesium. C. Sodium. D. Potassium. E. Boron. F. Lithium. G. Strontium. H. Manganese. I. Iron. J. Silica.

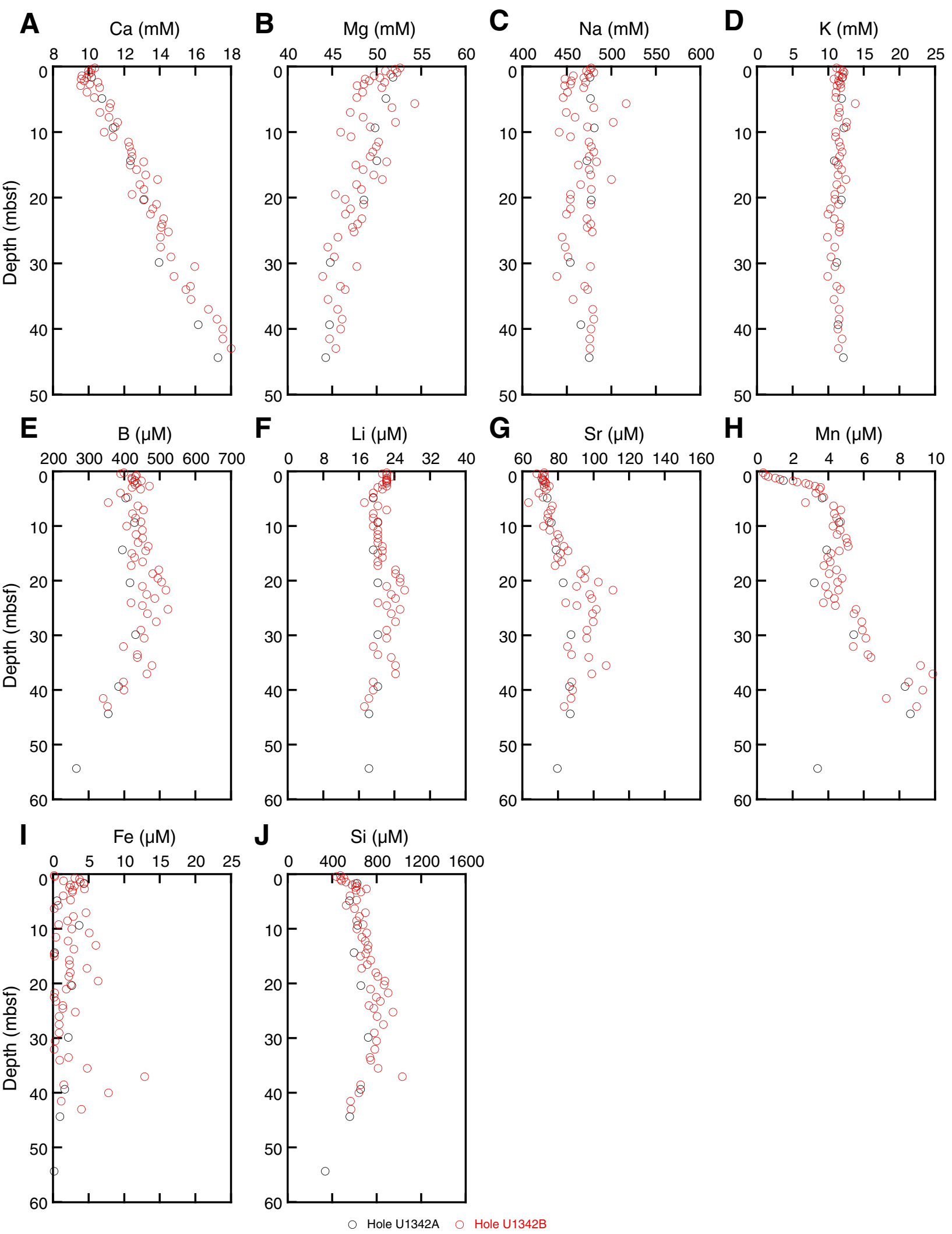


Figure F27. Solid-phase chemical concentrations, Holes U1342A and U1342B. A. Calcium carbonate $\left(\mathrm{CaCO}_{3}\right)$. B. Total organic carbon (TOC). C. Total sulfur (TS).

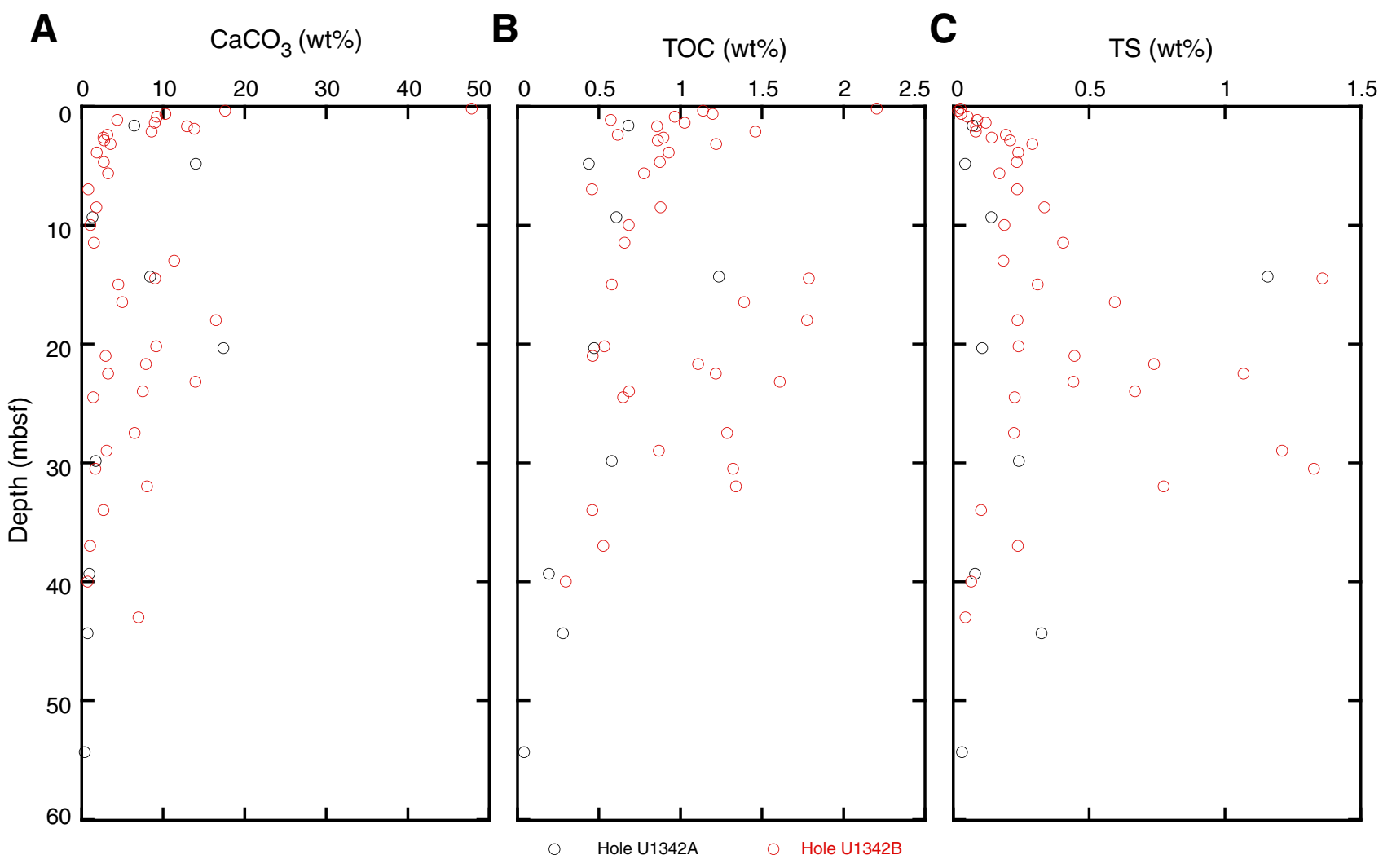


Figure F28. Comparison between solid-phase geochemical records and gamma ray attenuation (GRA) bulk density, Hole U1342B. A. Calcium carbonate $\left(\mathrm{CaCO}_{3}\right)$. B. Total organic carbon (TOC). C. Total sulfur (TS). Stars = data from solid-phase samples taken at a laminated layer. Green bars = estimated laminated layers recognized by gamma ray attenuation (GRA) bulk density.

Hole U1342B
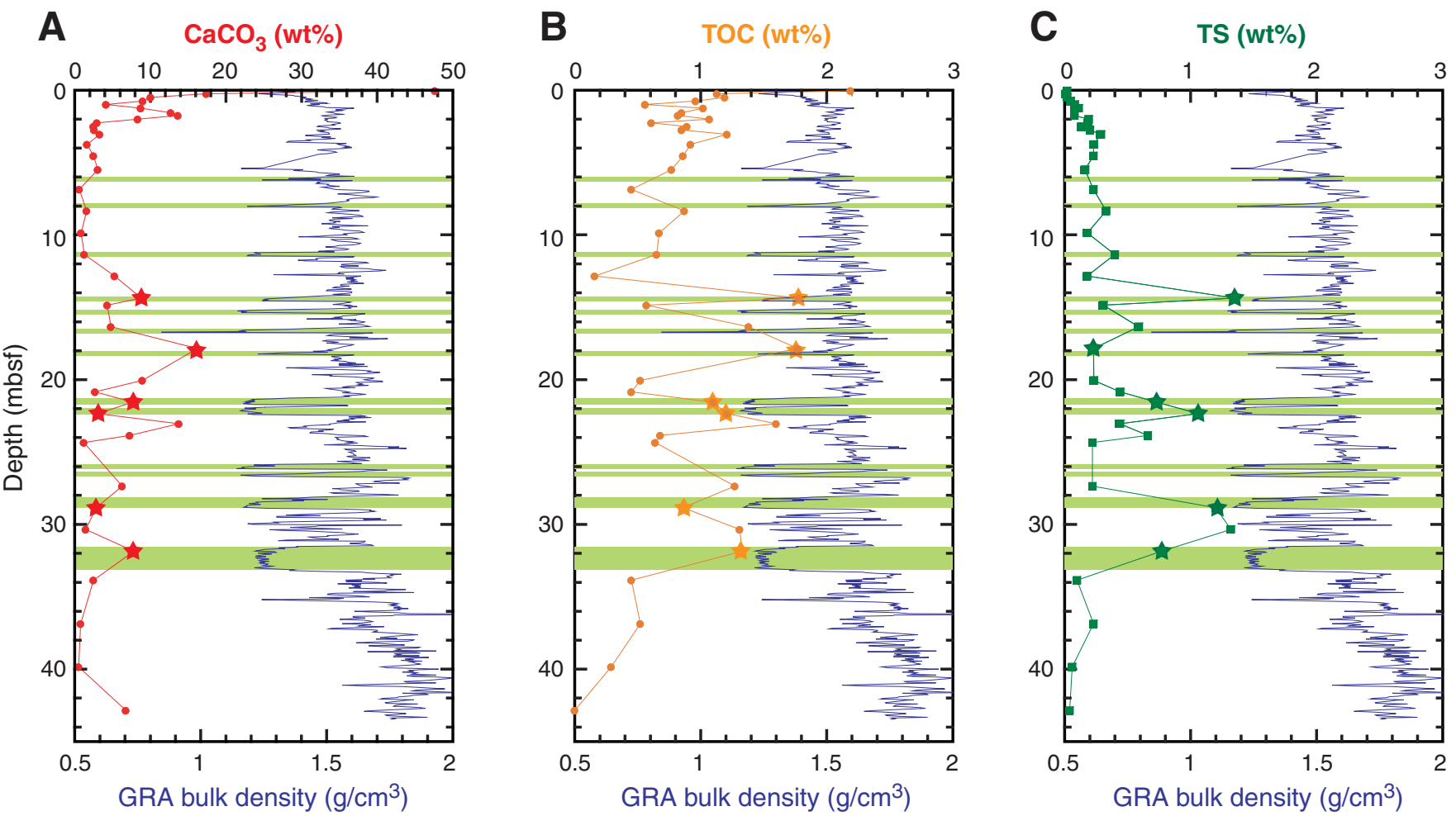

Squeeze-cake splits from whole rounds taken at laminated intervals

Estimated laminated sediments 
Figure F29. Downhole distribution of STMSL magnetic susceptibility, Hole U1342C.

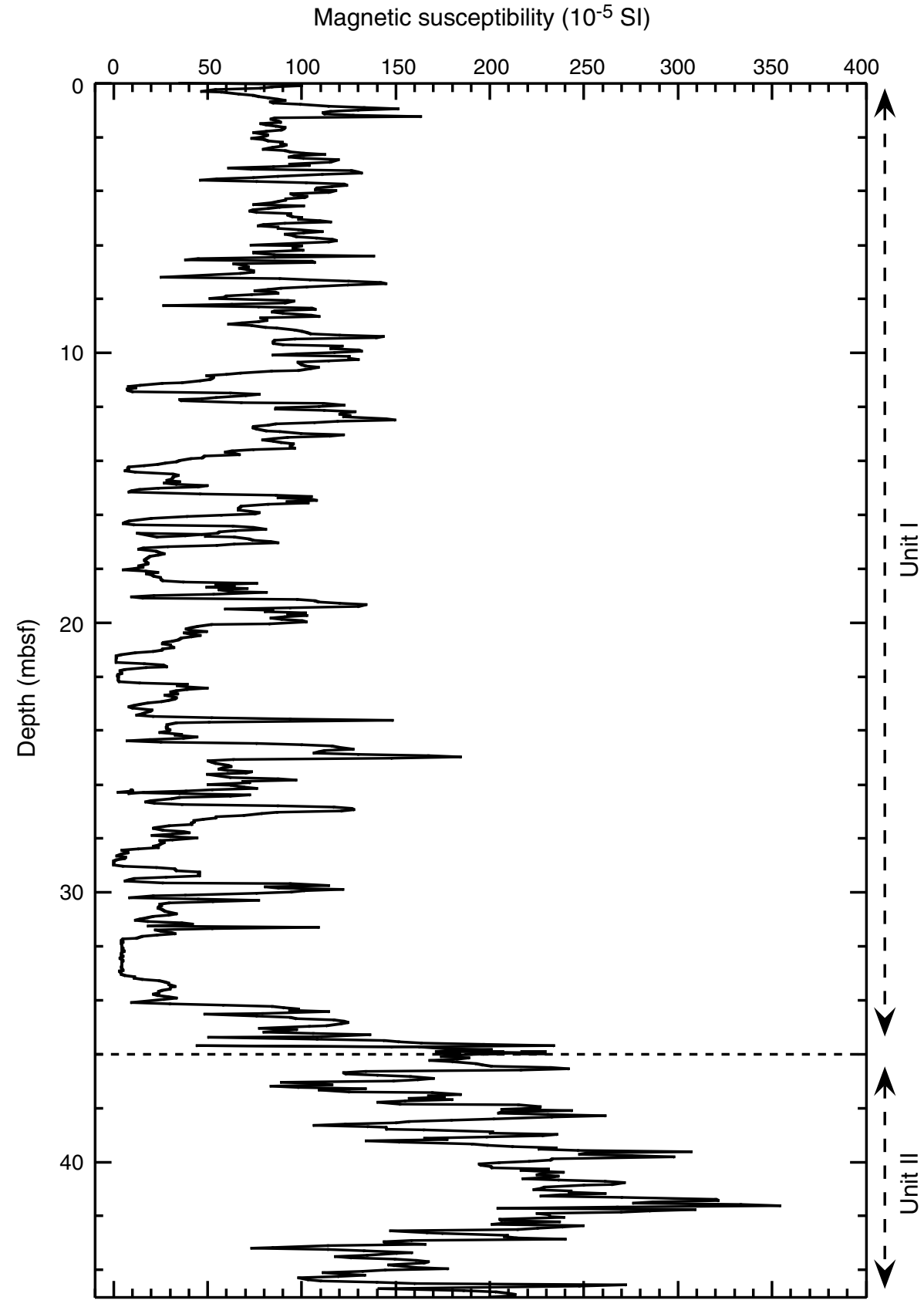


Figure F30. Downhole distribution of gamma ray attenuation (GRA) wet bulk density (solid line) and MAD measurements on sediment samples (open circles) collected from the working halves of split sections, Hole U1342C.

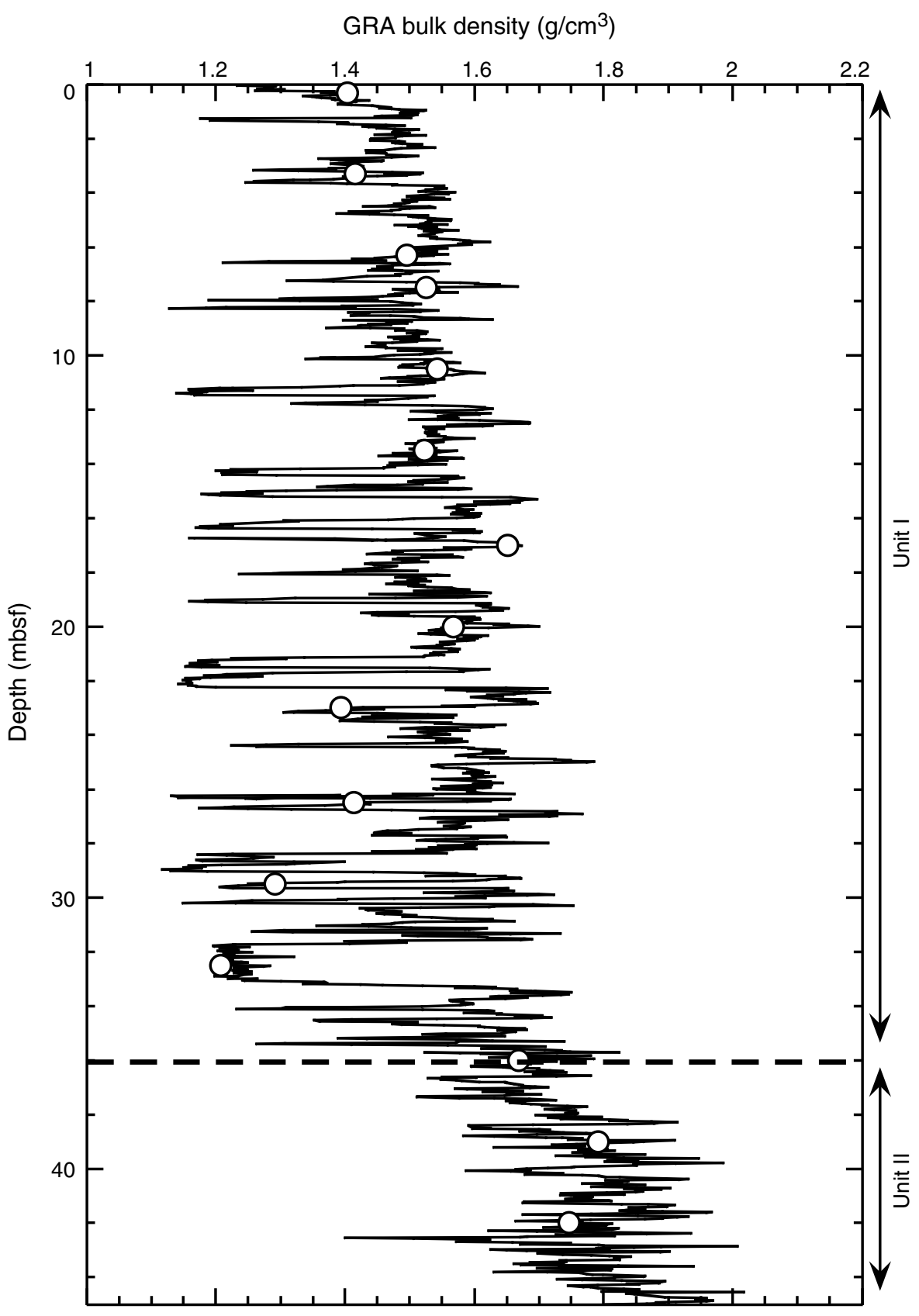


Figure F31. Downhole distribution of $P$-wave velocity recorded by the STMSL on whole-round sections, Hole U1342C.

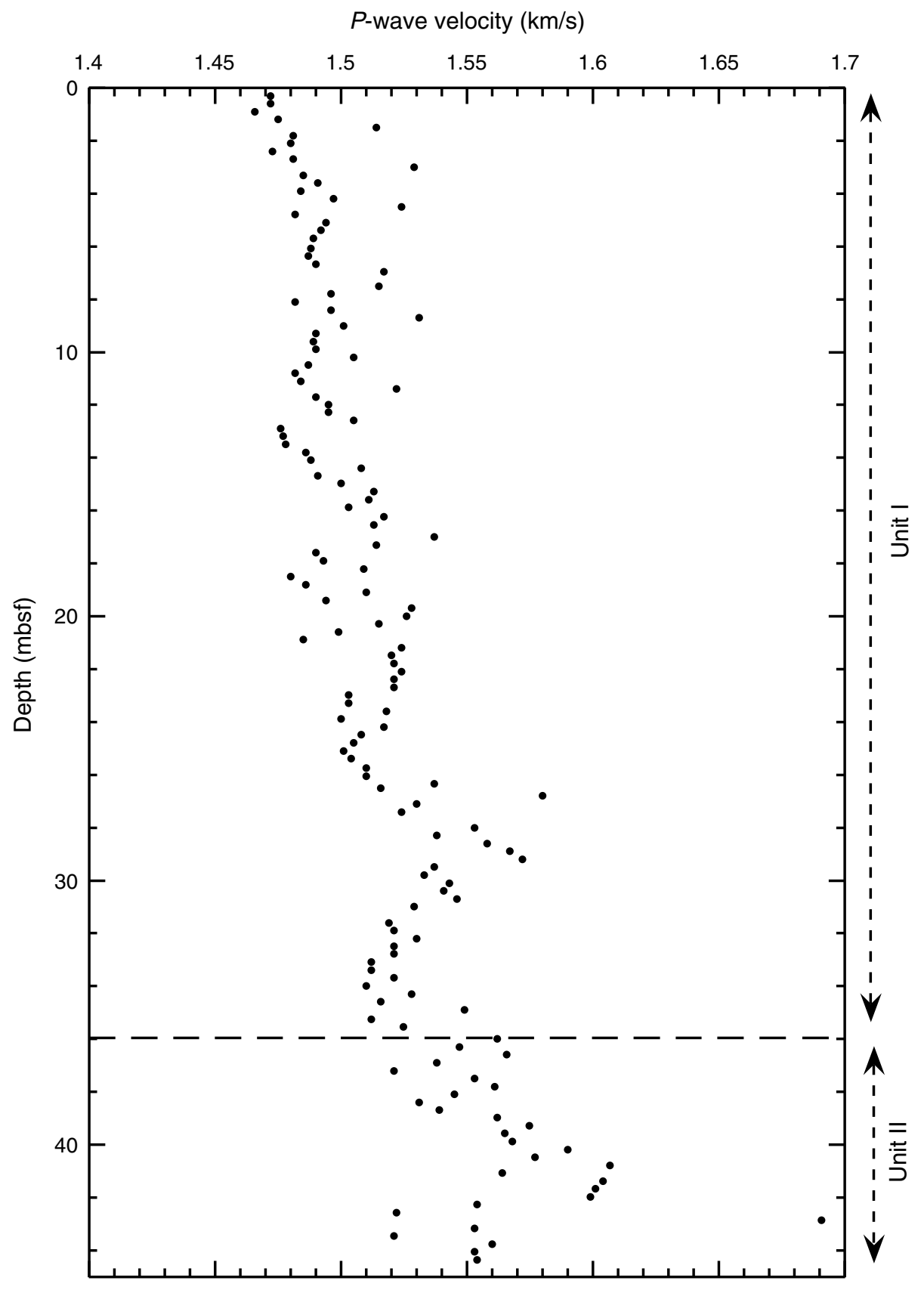


Figure F32. Downhole distribution of natural gamma radiation (NGR), Hole U1342C.

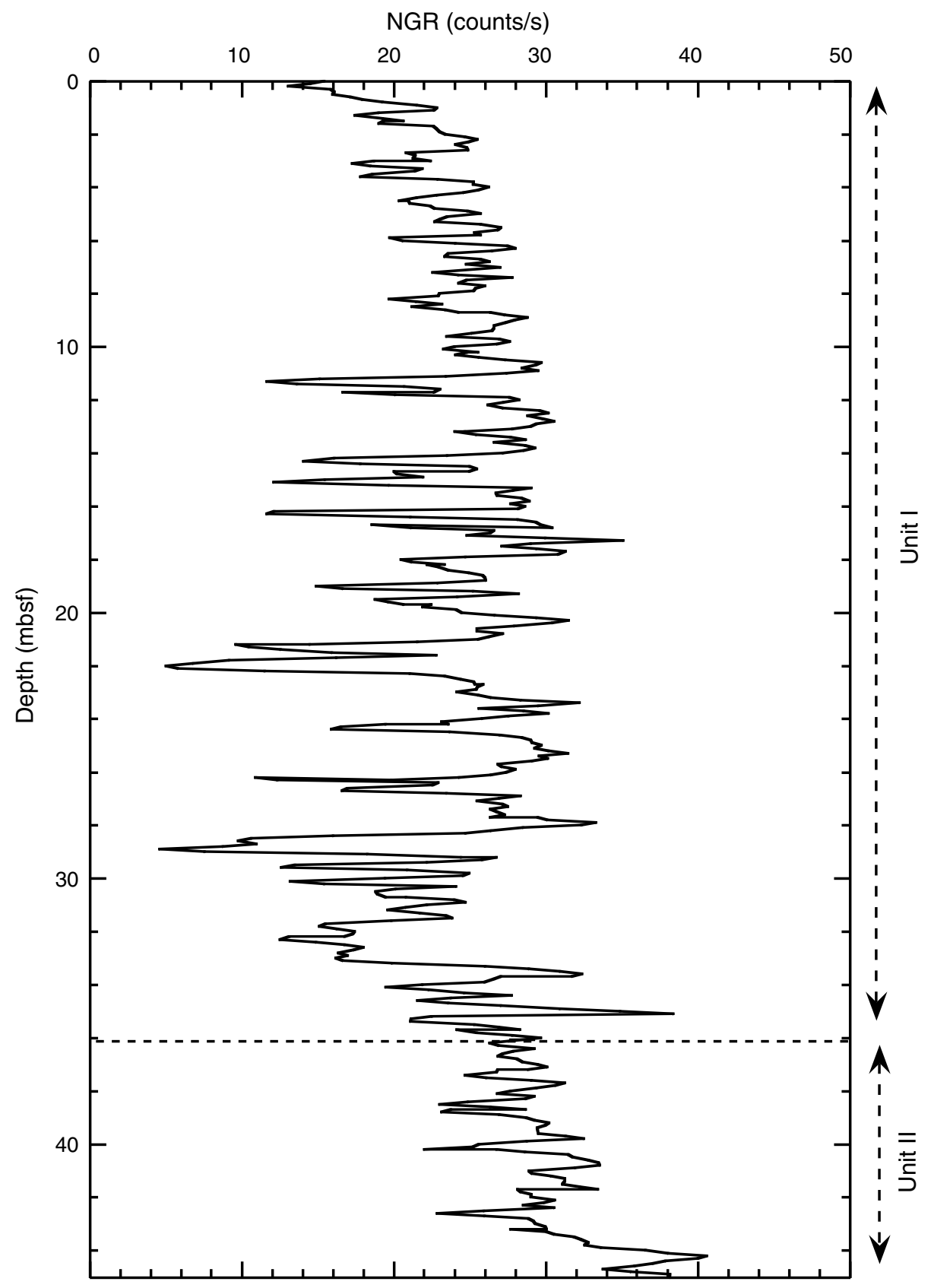


Figure F33. Downhole distribution of sediment water content (percent of total sediment weight) and porosity, Hole U1342C.

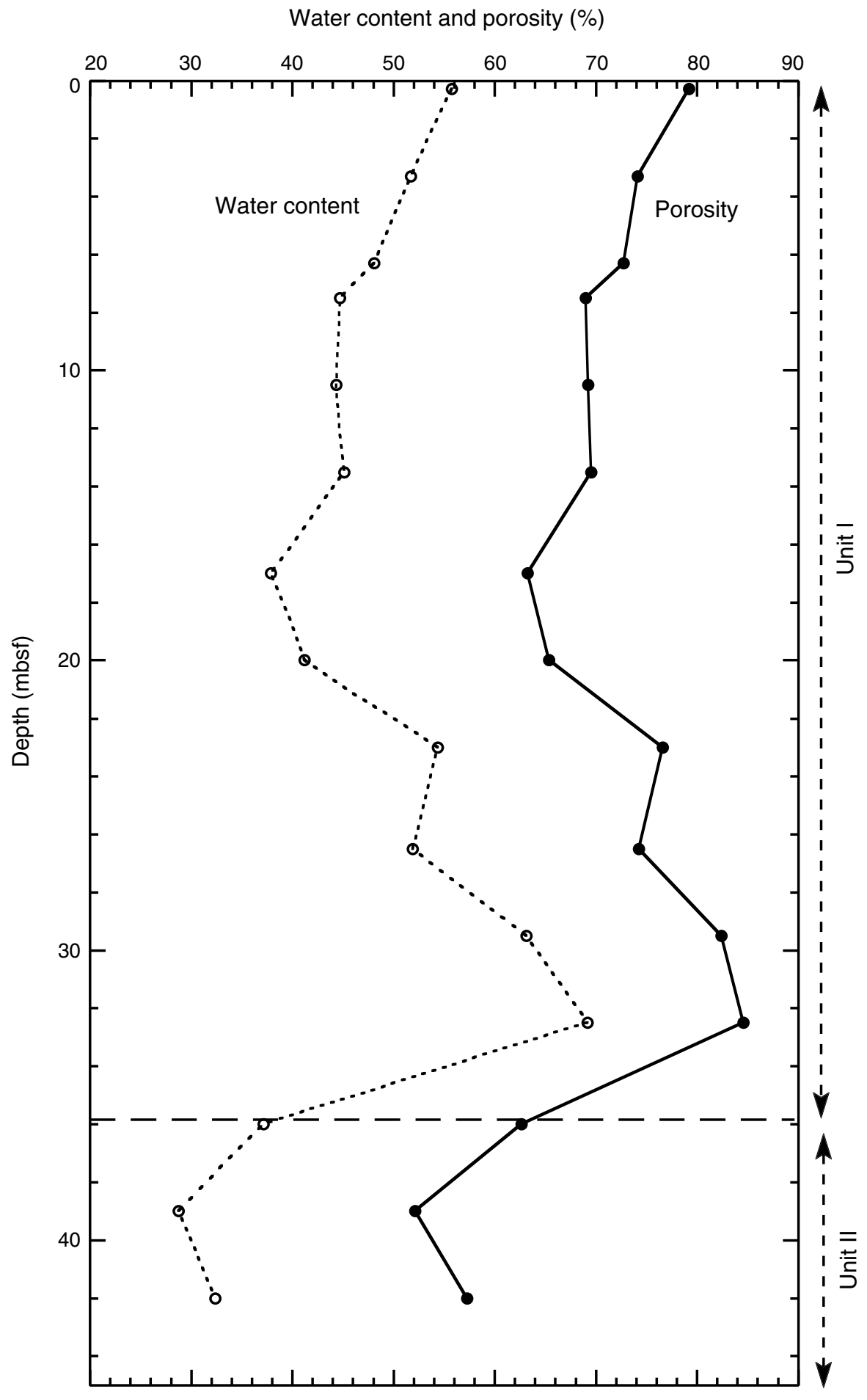


Figure F34. Downhole variations in dry grain density, Hole U1342C.

Dry grain density $\left(\mathrm{g} / \mathrm{cm}^{3}\right)$

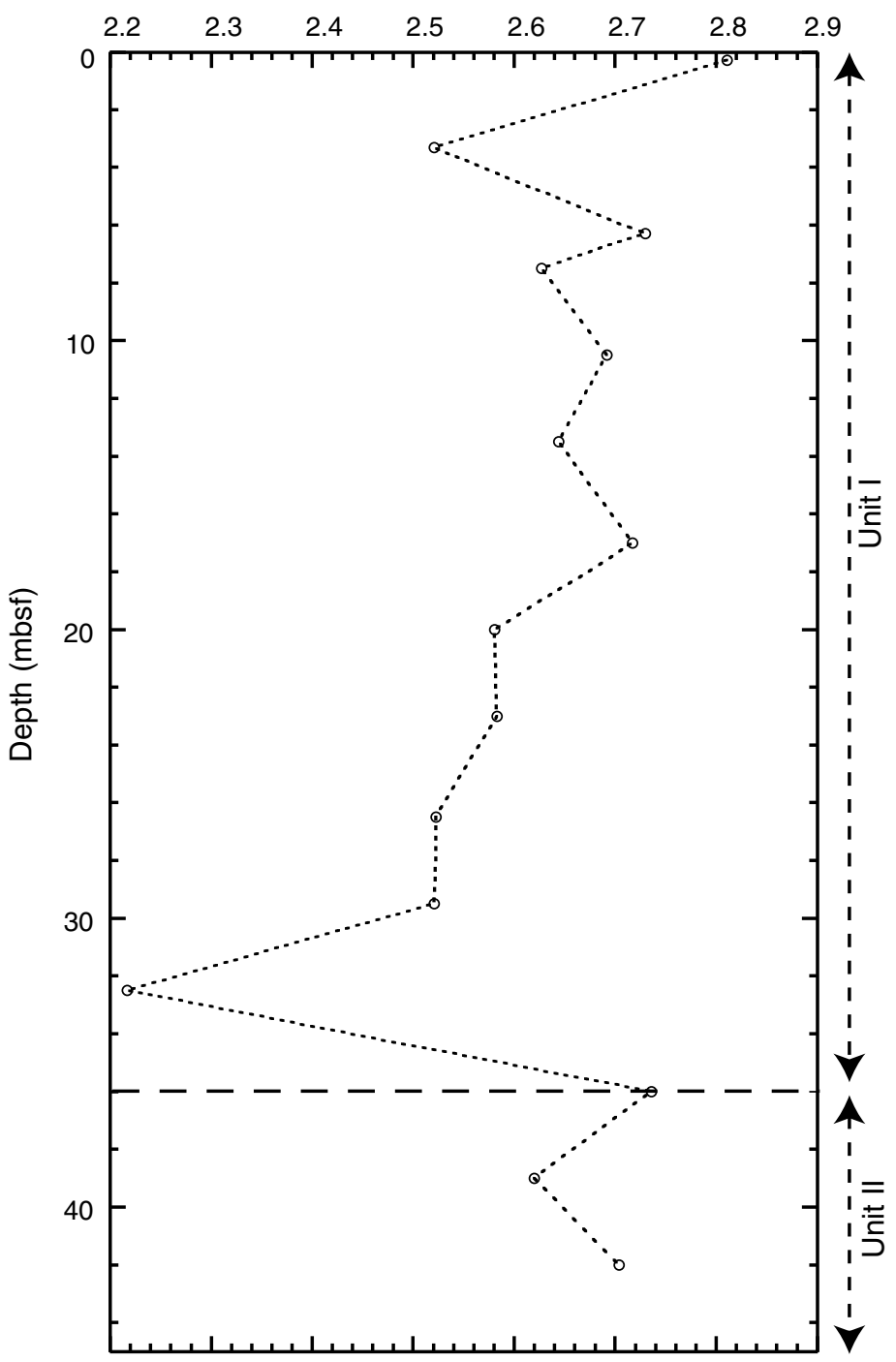


Figure F35. WRMSL magnetic susceptibility vs. composite depth, Site U1342. STMSL magnetic susceptibility data are shown for Hole U1342B because cores from this hole were not run through the WRMSL. For the splice record (top panel), depth on the CCSF-D scale is equivalent to depth on the CCSF-A scale.
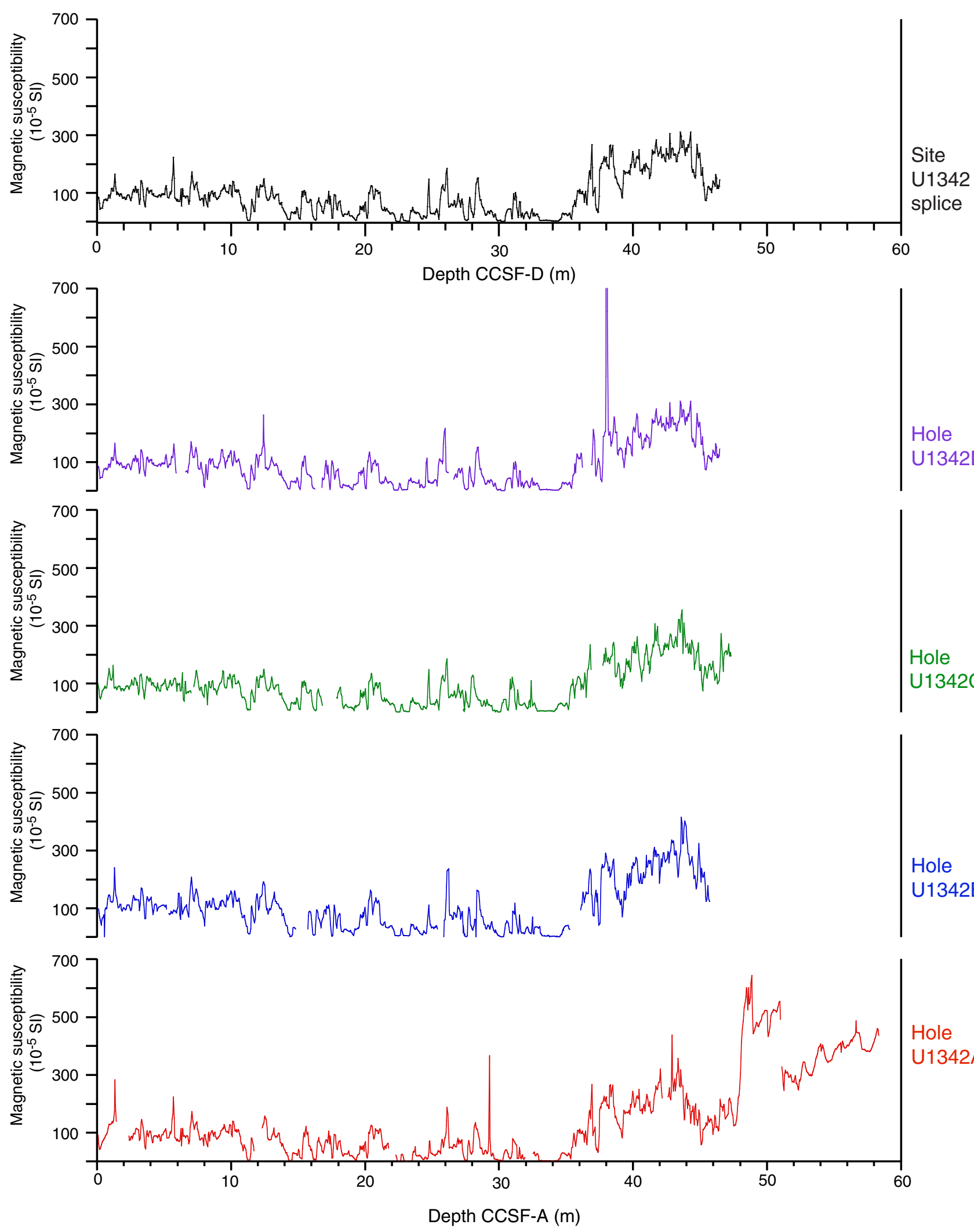
Figure F36. WRMSL gamma ray attenuation (GRA) bulk density vs. composite depth, Site U1342. STMSL GRA data are shown for Hole U1342B because cores from this hole were not run through the WRMSL. For the splice record (top panel), depth on the CCSF-D scale is equivalent to depth on the CCSF-A scale.
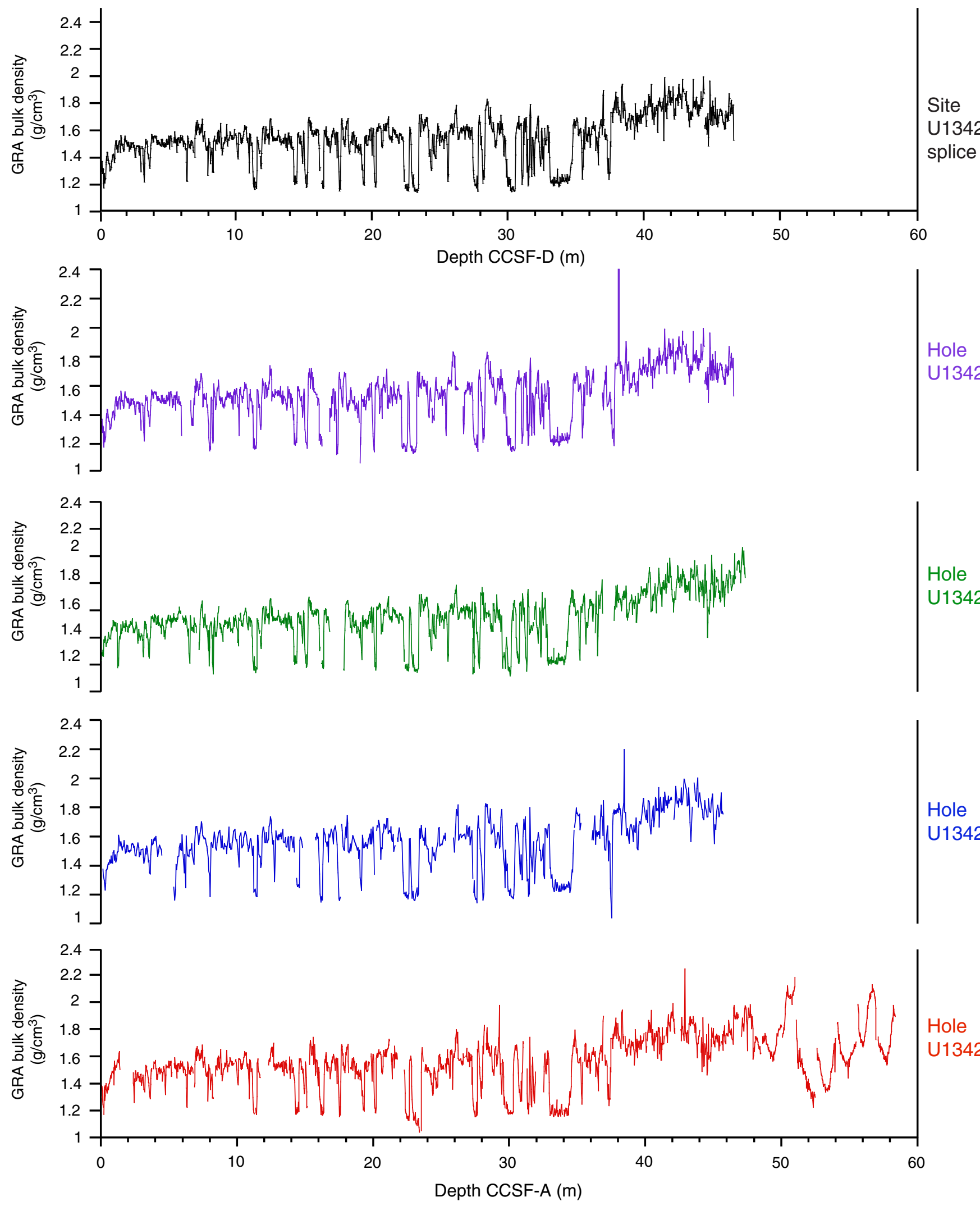
Figure F37. Natural gamma radiation (NGR) collected with the Natural Gamma Radiation Logger vs. composite depth, Site U1342. There are no NGR data for microbiology-dedicated Hole U1342B. For the splice record (top panel), depth on the CCSF-D scale is equivalent to depth on the CCSF-A scale.
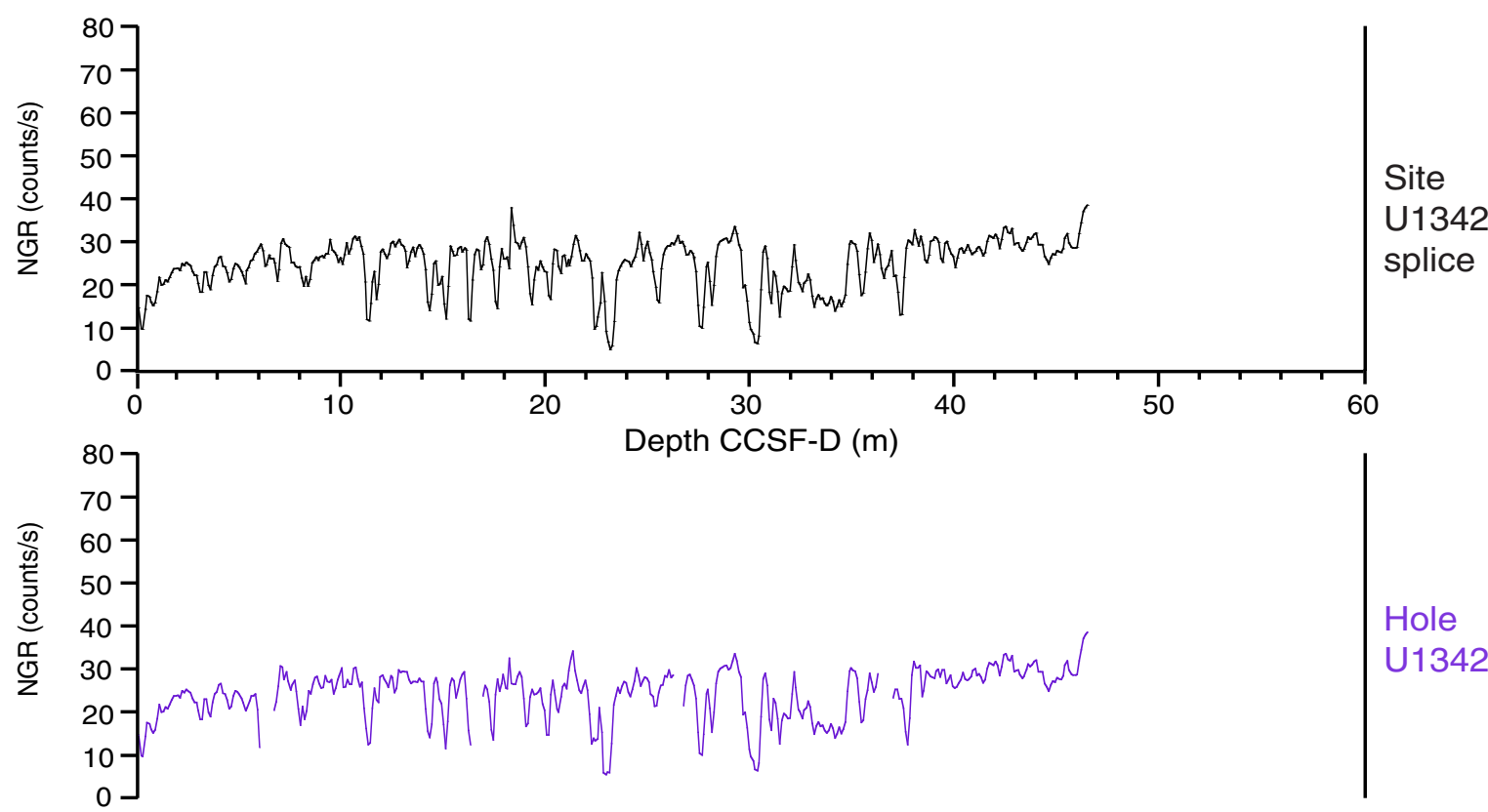

Hole

U1342D

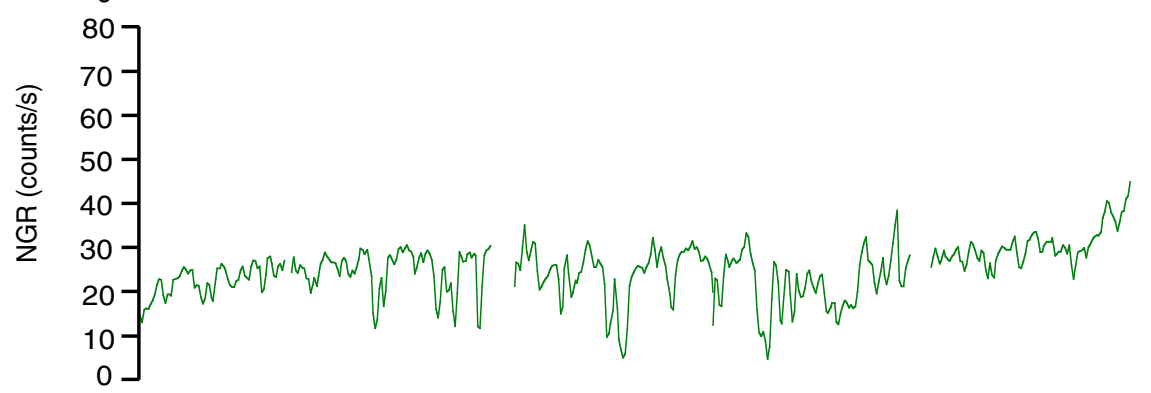

Hole

U1342C

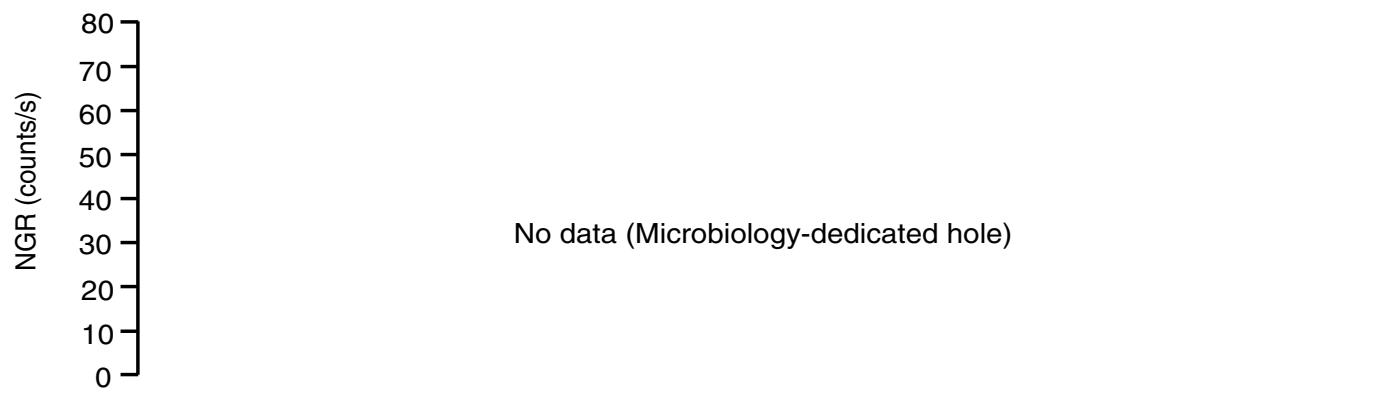

Hole

U1342B

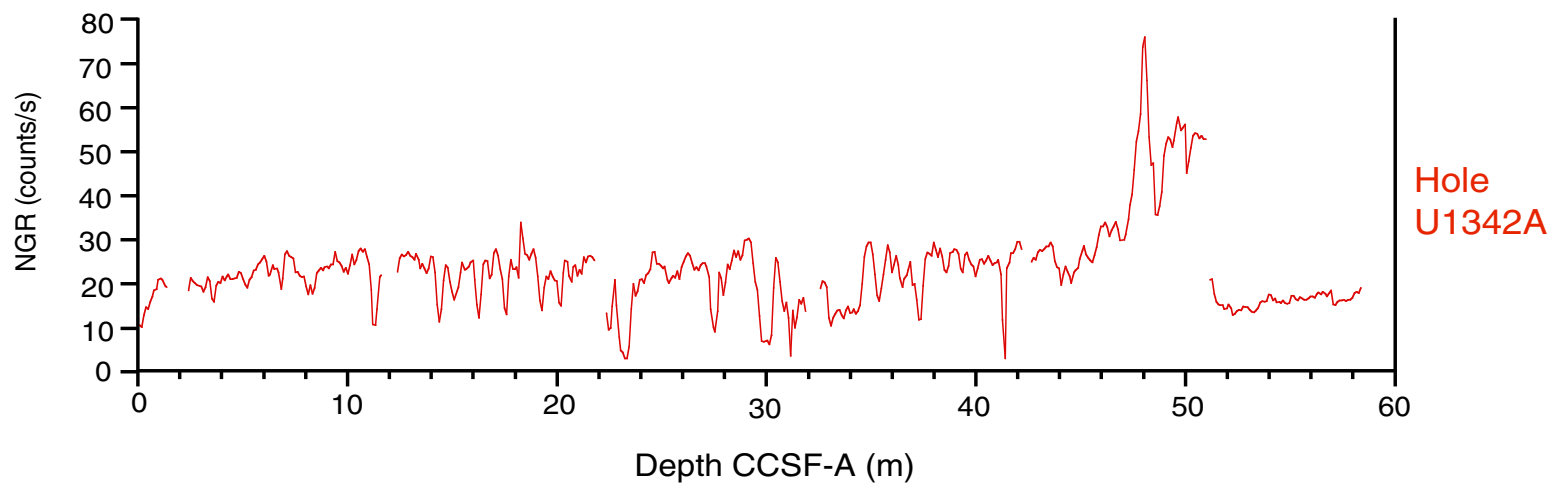


Expedition 323 Scientists

Site U1342

Figure F38. Color reflectance parameter $b^{*}$ collected with the SHMSL vs. composite depth, Site U1342. There are no color reflectance data for microbiology-dedicated Hole U1342B. For the splice record (top panel), depth on the CCSF-D scale is equivalent to depth on the CCSF-A scale.
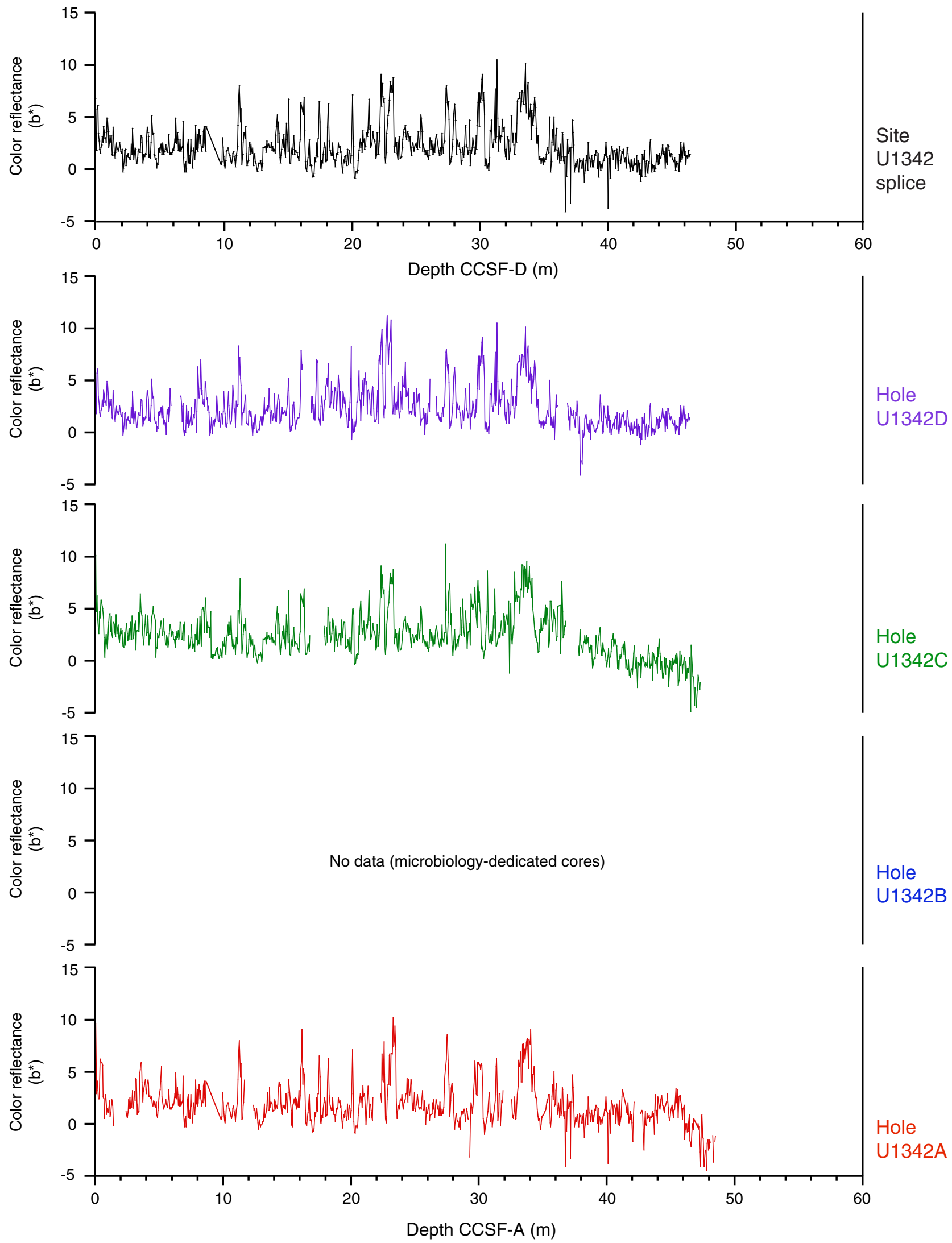

Proc. IODP | Volume 323

54 
Figure F39. Spliced composite records of magnetic susceptibility, WRMSL gamma ray attenuation (GRA) bulk density, and natural gamma radiation (NGR) vs. composite depth, Site U1342.
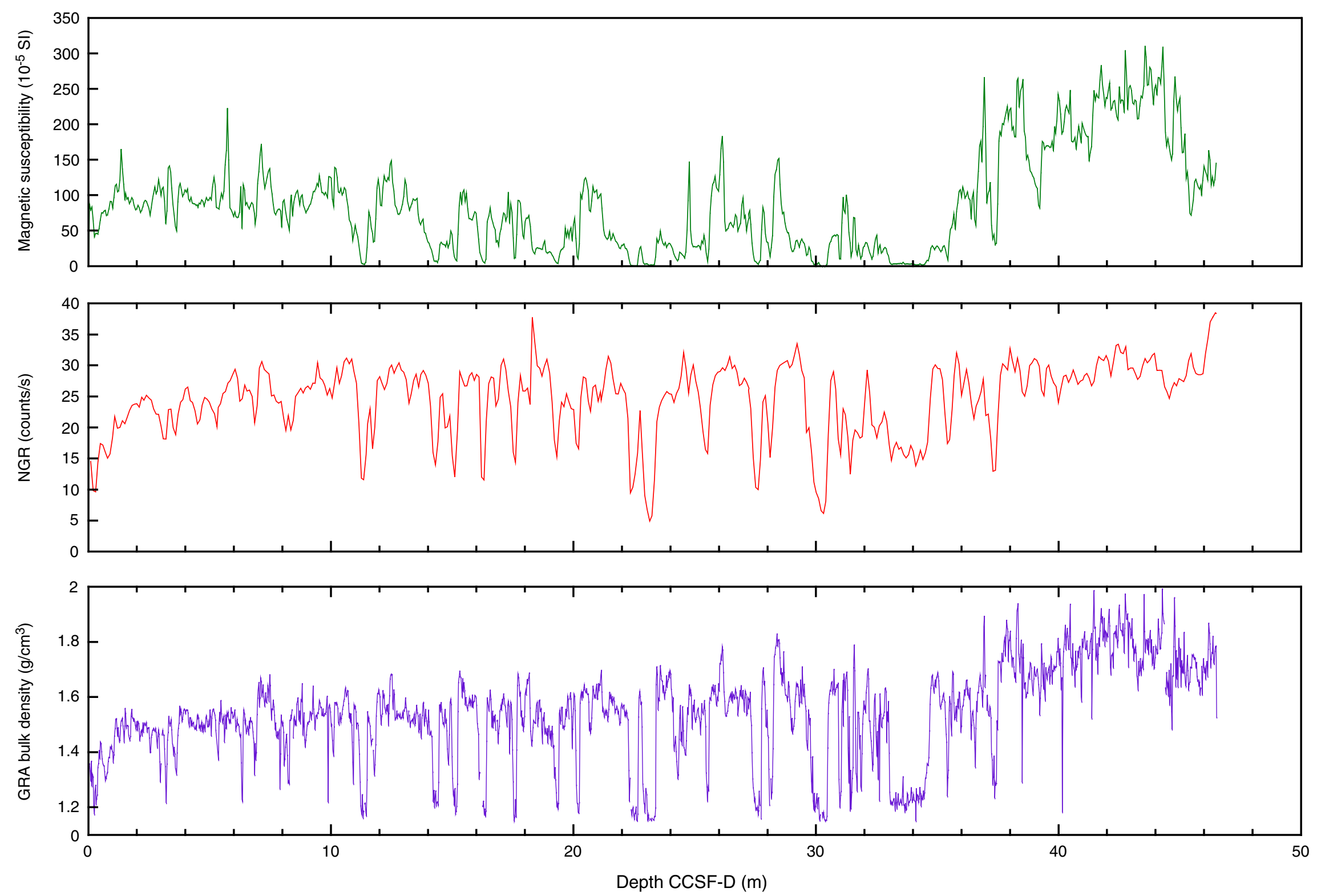
Figure F40. A. Mbsf vs. composite (CCSF-A) depth in the splice, Site U1342. A 1:1 line is also shown for comparison. B. Growth of cumulative depth offset $(\mathrm{m})$ vs. mbsf in the splice. The affine growth factor is 1.06.
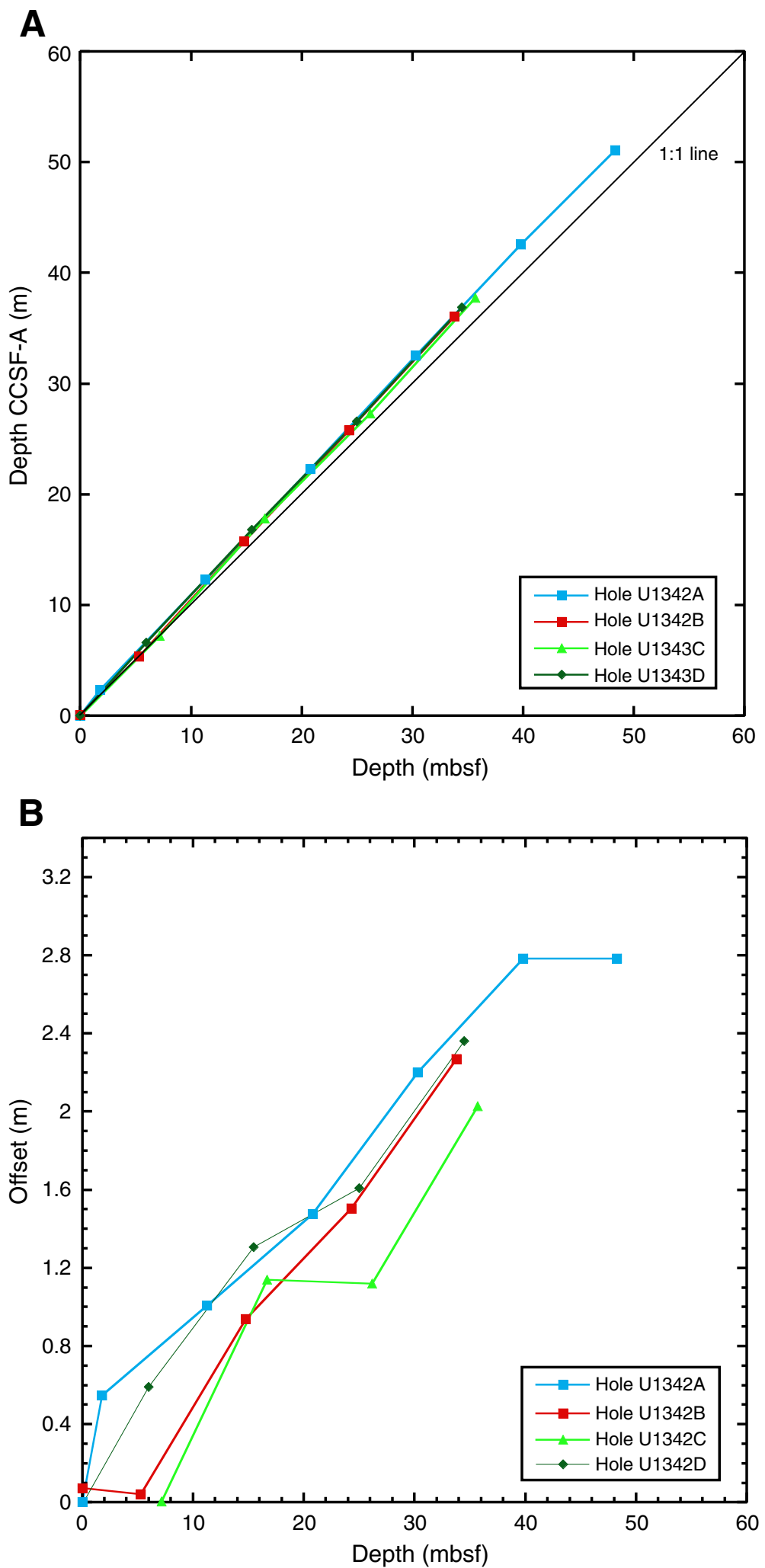
Figure F41. A. Records of APCT-3 penetrations and temperature decays, Hole U1342C. B. Summary of temperature measurements.

A
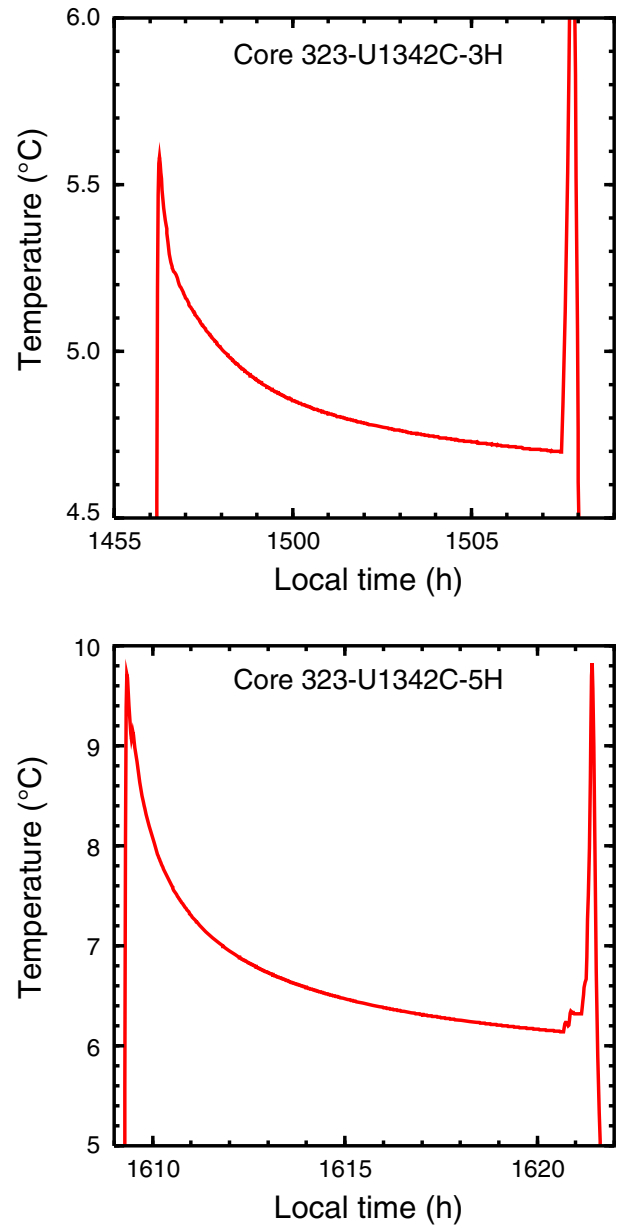

B

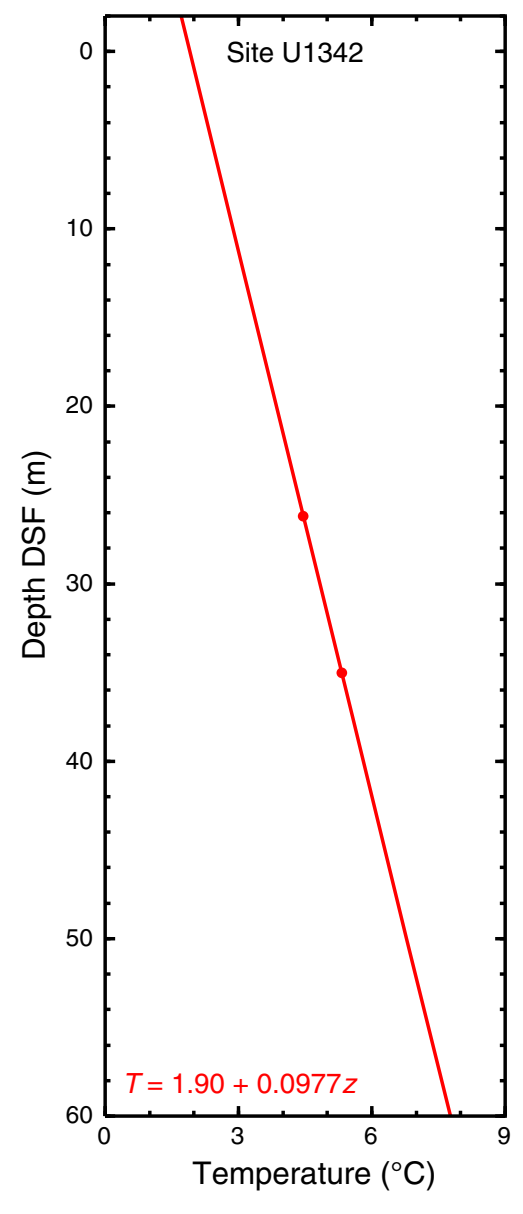


Figure F42. Summary of Bowers Ridge heat flow measurements recorded during Expedition 323 (black) compared with previously recorded values. All values are in $\mathrm{mW} / \mathrm{m}^{2}$; the global heat flow database of the international heat flow commission can be found at www.heatflow.und.edu/index.html.

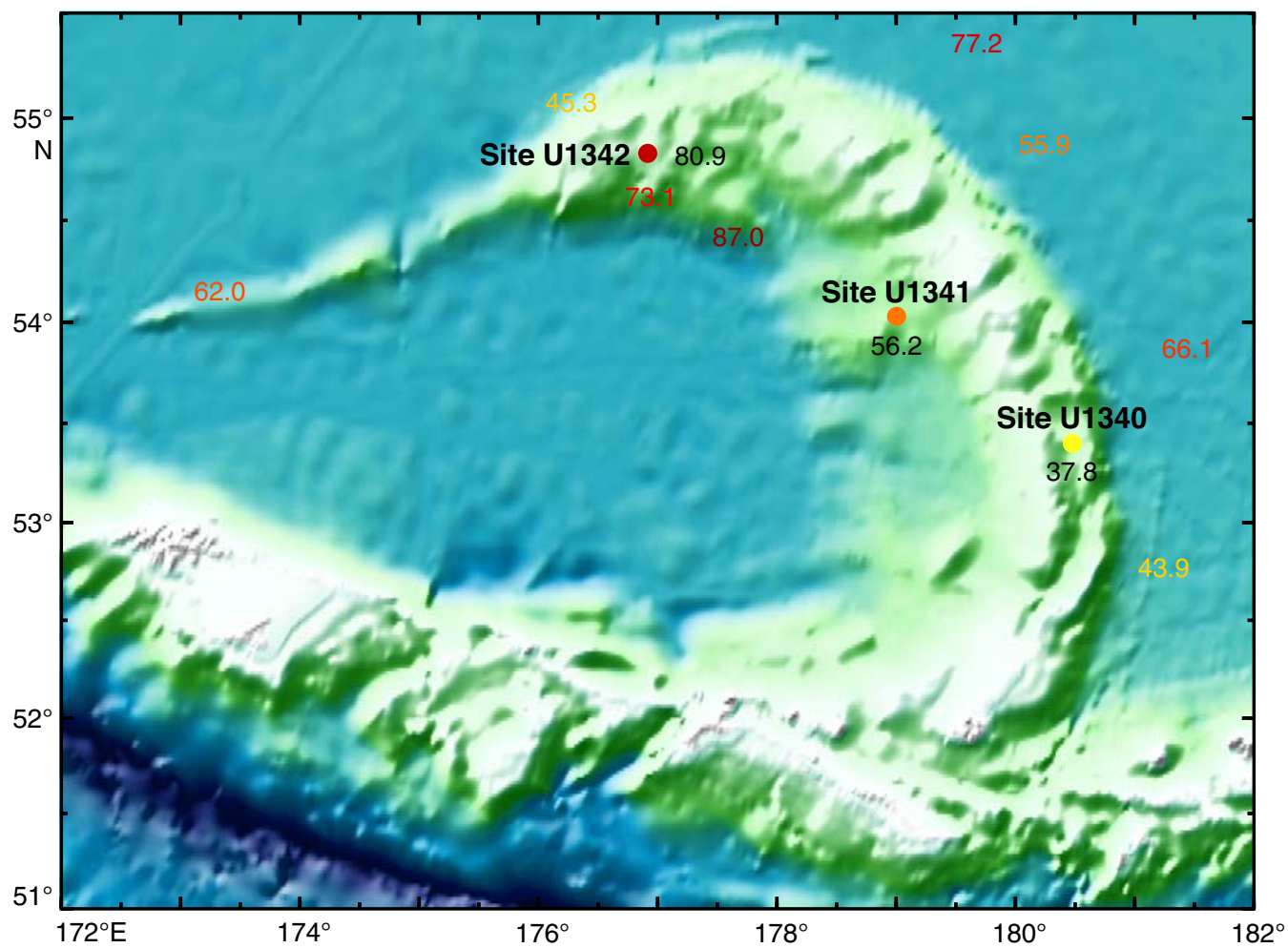


Table T1. Coring summary, Holes U1342A, U1342B, U1342C, and U1342D. (See table notes.) (Continued on next page.)

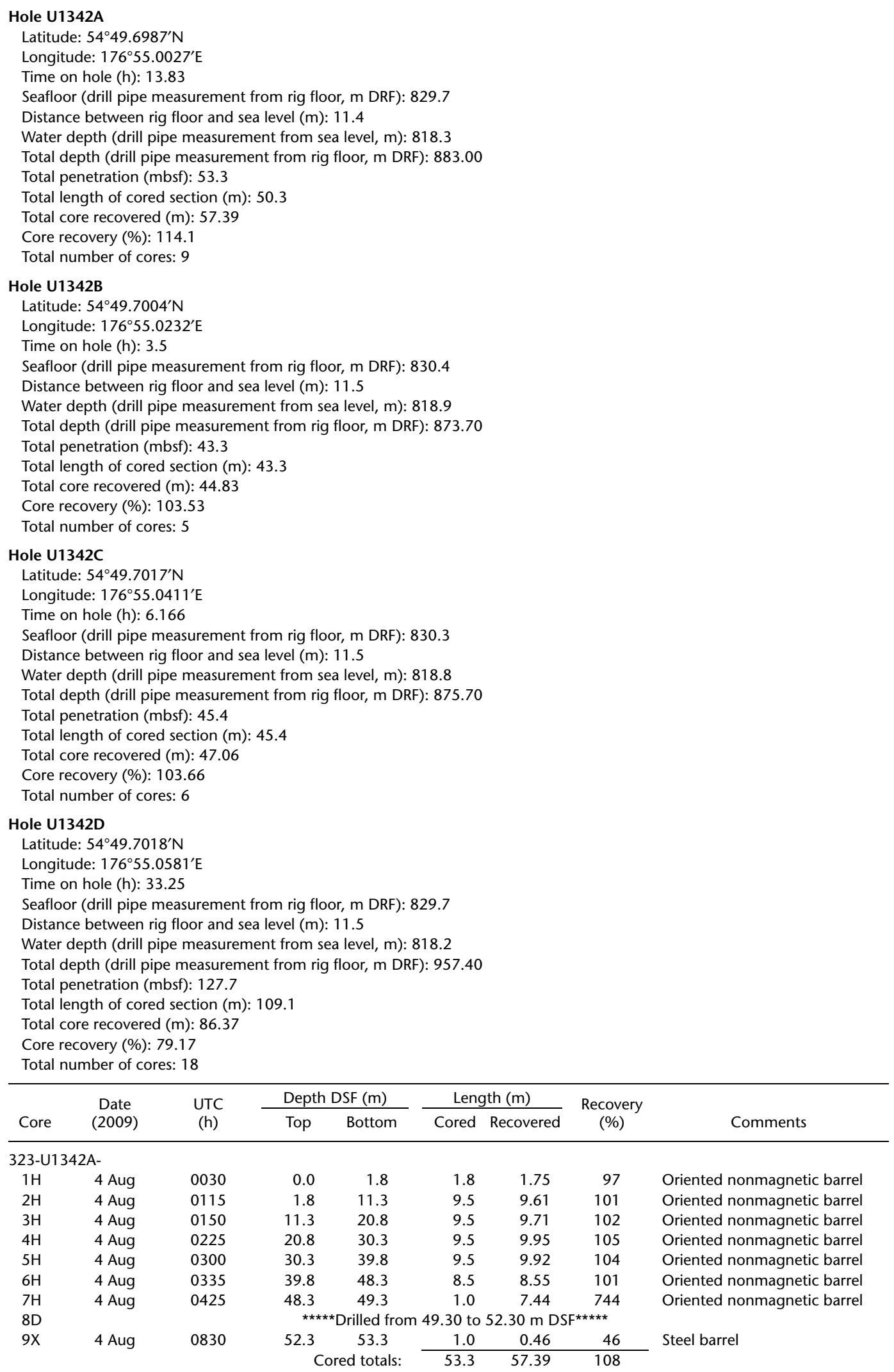

\begin{tabular}{|c|c|c|c|c|c|c|c|c|}
\hline \multirow[b]{2}{*}{ Core } & \multirow{2}{*}{$\begin{array}{l}\text { Date } \\
\text { (2009) }\end{array}$} & \multirow{2}{*}{$\begin{array}{l}\text { UTC } \\
\text { (h) }\end{array}$} & \multicolumn{2}{|c|}{ Depth DSF $(m)$} & \multicolumn{2}{|c|}{ Length $(\mathrm{m})$} & \multirow{2}{*}{$\begin{array}{c}\text { Recovery } \\
\text { (\%) }\end{array}$} & \multirow[b]{2}{*}{ Comments } \\
\hline & & & Top & Bottom & Cored & Recovered & & \\
\hline
\end{tabular}

\begin{tabular}{|c|c|c|c|c|c|c|c|c|}
\hline $1 \mathrm{H}$ & 4 Aug & 0030 & 0.0 & 1.8 & 1.8 & 1.75 & 97 & Oriented nonmagnetic barrel \\
\hline $2 \mathrm{H}$ & 4 Aug & 0115 & 1.8 & 11.3 & 9.5 & 9.61 & 101 & Oriented nonmagnetic barrel \\
\hline $3 \mathrm{H}$ & 4 Aug & 0150 & 11.3 & 20.8 & 9.5 & 9.71 & 102 & Oriented nonmagnetic barrel \\
\hline $4 \mathrm{H}$ & 4 Aug & 0225 & 20.8 & 30.3 & 9.5 & 9.95 & 105 & Oriented nonmagnetic barrel \\
\hline $5 \mathrm{H}$ & 4 Aug & 0300 & 30.3 & 39.8 & 9.5 & 9.92 & 104 & Oriented nonmagnetic barrel \\
\hline $6 \mathrm{H}$ & 4 Aug & 0335 & 39.8 & 48.3 & 8.5 & 8.55 & 101 & Oriented nonmagnetic barrel \\
\hline $7 \mathrm{H}$ & 4 Aug & 0425 & 48.3 & 49.3 & 1.0 & 7.44 & 744 & Oriented nonmagnetic barrel \\
\hline $8 \mathrm{D}$ & \multicolumn{8}{|c|}{ 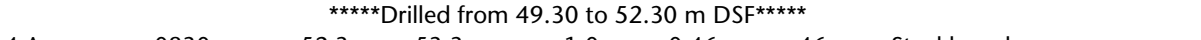 } \\
\hline $9 \mathrm{X}$ & 4 Aug & 0830 & 52.3 & 53.3 & 1.0 & 0.46 & 46 & Steel barrel \\
\hline
\end{tabular}


Table T1 (continued).

\begin{tabular}{|c|c|c|c|c|c|c|c|c|}
\hline \multirow[b]{2}{*}{ Core } & \multirow{2}{*}{$\begin{array}{l}\text { Date } \\
(2009)\end{array}$} & \multirow{2}{*}{$\begin{array}{l}\text { UTC } \\
\text { (h) }\end{array}$} & \multicolumn{2}{|c|}{ Depth DSF (m) } & \multicolumn{2}{|c|}{ Length $(\mathrm{m})$} & \multirow{2}{*}{$\begin{array}{l}\text { Recovery } \\
\text { (\%) }\end{array}$} & \multirow[b]{2}{*}{ Comments } \\
\hline & & & Top & Bottom & Cored & $\overline{\text { Recovered }}$ & & \\
\hline \multicolumn{9}{|c|}{ 323-U1342B- } \\
\hline $1 \mathrm{H}$ & 4 Aug & 1025 & 0.0 & 5.3 & 5.3 & 5.33 & 101 & Oriented nonmagnetic barrel \\
\hline $2 \mathrm{H}$ & 4 Aug & 1100 & 5.3 & 14.8 & 9.5 & 9.78 & 103 & Oriented nonmagnetic barrel \\
\hline $3 \mathrm{H}$ & 4 Aug & 1135 & 14.8 & 24.3 & 9.5 & 10.01 & 105 & Oriented nonmagnetic barrel \\
\hline $4 \mathrm{H}$ & 4 Aug & 1150 & 24.3 & 33.8 & 9.5 & 9.77 & 103 & Oriented nonmagnetic barrel \\
\hline \multirow[t]{2}{*}{$5 \mathrm{H}$} & 4 Aug & 1220 & 33.8 & 43.3 & 9.5 & 9.94 & 105 & Oriented nonmagnetic barrel \\
\hline & & & \multicolumn{2}{|c|}{ Cored totals: } & 43.3 & 44.83 & 104 & \\
\hline \multicolumn{9}{|c|}{ 323-U1342C- } \\
\hline $1 \mathrm{H}$ & 4 Aug & 1345 & 0.0 & 7.2 & 7.2 & 7.22 & 100 & Oriented nonmagnetic barrel \\
\hline $2 \mathrm{H}$ & 4 Aug & 1430 & 7.2 & 16.7 & 9.5 & 9.84 & 104 & Oriented nonmagnetic barrel \\
\hline $3 \mathrm{H}$ & 4 Aug & 1515 & 16.7 & 26.2 & 9.5 & 10.00 & 105 & Oriented nonmagnetic barrel \\
\hline $4 \mathrm{H}$ & 4 Aug & 1545 & 26.2 & 35.7 & 9.5 & 9.80 & 103 & Oriented nonmagnetic barrel \\
\hline $5 \mathrm{H}$ & 4 Aug & 1629 & 35.7 & 45.2 & 9.5 & 9.98 & 105 & Oriented nonmagnetic barrel \\
\hline \multirow[t]{2}{*}{$6 \mathrm{H}$} & 4 Aug & 1800 & 45.2 & 45.4 & 0.2 & 0.22 & 110 & Oriented nonmagnetic barrel \\
\hline & & & \multicolumn{2}{|c|}{ Cored totals: } & 45.4 & 47.06 & 104 & \\
\hline \multicolumn{9}{|c|}{ 323-U1342D- } \\
\hline $1 \mathrm{H}$ & 4 Aug & 1940 & 0.0 & 6.0 & 6.0 & 6.11 & 102 & Oriented nonmagnetic barrel \\
\hline $2 \mathrm{H}$ & 4 Aug & 2010 & 6.0 & 15.5 & 9.5 & 9.83 & 103 & Oriented nonmagnetic barrel \\
\hline $3 \mathrm{H}$ & 4 Aug & 2040 & 15.5 & 25.0 & 9.5 & 9.62 & 101 & Oriented nonmagnetic barrel \\
\hline $4 \mathrm{H}$ & 4 Aug & 2110 & 25.0 & 34.5 & 9.5 & 9.83 & 103 & Oriented nonmagnetic barrel \\
\hline $5 \mathrm{H}$ & 4 Aug & 2140 & 34.5 & 44.0 & 9.5 & 9.90 & 104 & Oriented nonmagnetic barrel \\
\hline $6 \mathrm{D}$ & \multicolumn{8}{|c|}{${ }^{* \star * \star *}$ Drilled from 44.00 to $62.60 \mathrm{~m} \mathrm{DSF}^{\star \star * \star \star *}$} \\
\hline $7 \mathrm{X}$ & 5 Aug & 0255 & 62.6 & 66.6 & 4.0 & 0.55 & 14 & Steel barrel \\
\hline $8 \mathrm{x}$ & 5 Aug & 0515 & 66.6 & 71.6 & 5.0 & 1.66 & 33 & Steel barrel \\
\hline $9 \mathrm{X}$ & 5 Aug & 0625 & 71.6 & 75.6 & 4.0 & 3.84 & 96 & Steel barrel \\
\hline $10 x$ & 5 Aug & 0825 & 75.6 & 82.1 & 6.5 & 4.66 & 72 & Steel barrel \\
\hline $11 \mathrm{X}$ & 5 Aug & 1030 & 82.1 & 87.9 & 5.8 & 3.34 & 58 & Steel barrel \\
\hline $12 x$ & 5 Aug & 1210 & 87.9 & 90.1 & 2.2 & 2.01 & 91 & Steel barrel \\
\hline $13 x$ & 5 Aug & 1340 & 90.1 & 94.9 & 4.8 & 4.64 & 97 & Steel barrel \\
\hline $14 X$ & 5 Aug & 1530 & 94.9 & 102.5 & 7.6 & 3.48 & 46 & Steel barrel \\
\hline $15 X$ & 5 Aug & 1710 & 102.5 & 106.1 & 3.6 & 1.48 & 41 & Steel barrel \\
\hline $16 \mathrm{X}$ & 5 Aug & 1840 & 106.1 & 115.1 & 9.0 & 2.49 & 28 & Steel barrel \\
\hline $17 X$ & 5 Aug & 2030 & 115.1 & 117.7 & 2.6 & 5.70 & 219 & Steel barrel \\
\hline $18 \mathrm{X}$ & 5 Aug & 2105 & 117.7 & 121.7 & 4.0 & 3.00 & 75 & Steel barrel \\
\hline \multirow[t]{3}{*}{$19 \mathrm{X}$} & 5 Aug & 2340 & 121.7 & 127.7 & 6.0 & 4.23 & 70 & Steel barrel \\
\hline & & & \multicolumn{2}{|c|}{ Cored totals: } & 127.7 & 86.37 & 79 & \\
\hline & & & \multicolumn{2}{|c|}{ Site totals: } & 269.7 & 235.65 & 94.98 & \\
\hline
\end{tabular}

Notes: DRF $=$ drilling depth below rig floor, $\mathrm{mbsf}=$ meters below seafloor, DSF $=$ drilling depth below seafloor. UTC $=$ Universal Time Coordinated.

Table T2. Datum events of radiolarians, diatoms, calcareous nannofossils, and silicoflagellates, Holes U1342A, U1342B, U1342C, and U1342D. (See table notes.)

\begin{tabular}{|c|c|c|c|c|c|c|c|c|c|c|}
\hline \multirow[b]{2}{*}{ Datum event } & \multirow[b]{2}{*}{ Taxon } & \multirow[b]{2}{*}{$\begin{array}{l}\text { Age } \\
(\mathrm{Ma})\end{array}$} & \multicolumn{4}{|c|}{ Depth (mbsf) } & \multicolumn{4}{|c|}{ Depth CCSF-A (m) } \\
\hline & & & $\begin{array}{c}\text { Hole } \\
\text { U1342A }\end{array}$ & $\begin{array}{c}\text { Hole } \\
\text { U1342B }\end{array}$ & $\begin{array}{c}\text { Hole } \\
\text { U1342C }\end{array}$ & $\begin{array}{c}\text { Hole } \\
\text { U1342D }\end{array}$ & $\begin{array}{c}\text { Hole } \\
\text { U1342A }\end{array}$ & $\begin{array}{c}\text { Hole } \\
\text { U1342B }\end{array}$ & $\begin{array}{c}\text { Hole } \\
\text { U1342C }\end{array}$ & $\begin{array}{c}\text { Hole } \\
\text { U1342D }\end{array}$ \\
\hline LO Lychnocanoma nipponica sakaii & Radiolarian & 0.05 & 0.9 & 2.7 & 3.6 & 3.1 & 0.9 & 2.7 & 3.6 & 3.0 \\
\hline LO Amphimelissa setosa & Radiolarian & $0.08-1$ & - & - & 3.6 & - & - & - & 3.6 & - \\
\hline LO Spongodiscus sp. & Radiolarian & $0.28-0.32$ & 6.6 & 10.2 & 12.1 & 11.0 & 6.8 & 10.1 & 11.9 & 11.0 \\
\hline LO Axoprunum acquilonium & Radiolarian & $0.25-0.43$ & 16.2 & 19.8 & 12.1 & 20.5 & 16.8 & 20.0 & 11.9 & 21.2 \\
\hline LO Proboscia curvirostris & Diatom & 0.3 & 16.2 & 10.2 & 21.8 & 11.0 & 16.8 & 10.1 & 22.0 & 11.0 \\
\hline LO Pseudoemiliania lacunosa & Calcareous nannofossil & 0.44 & 16.2 & - & - & - & 16.8 & - & - & - \\
\hline LO Dictyocha subarctios & Silicoflagellate & $0.73-0.75$ & 25.9 & - & - & 30.0 & 26.8 & - & - & 31.2 \\
\hline LO Eucyrtidium matuyamai & Radiolarian & $0.9-1.5$ & - & 29.3 & - & - & - & 30.3 & - & - \\
\hline
\end{tabular}

Notes: For last occurrences (LO), the depth was estimated as the midpoint between the depth at which the species was last observed and the depth of the next sample above. $-=$ not applicable. 
Table T3. Calcareous nannofossil range chart, Holes U1342A, U1342B, U1342C, and U1342D. (See table notes.)

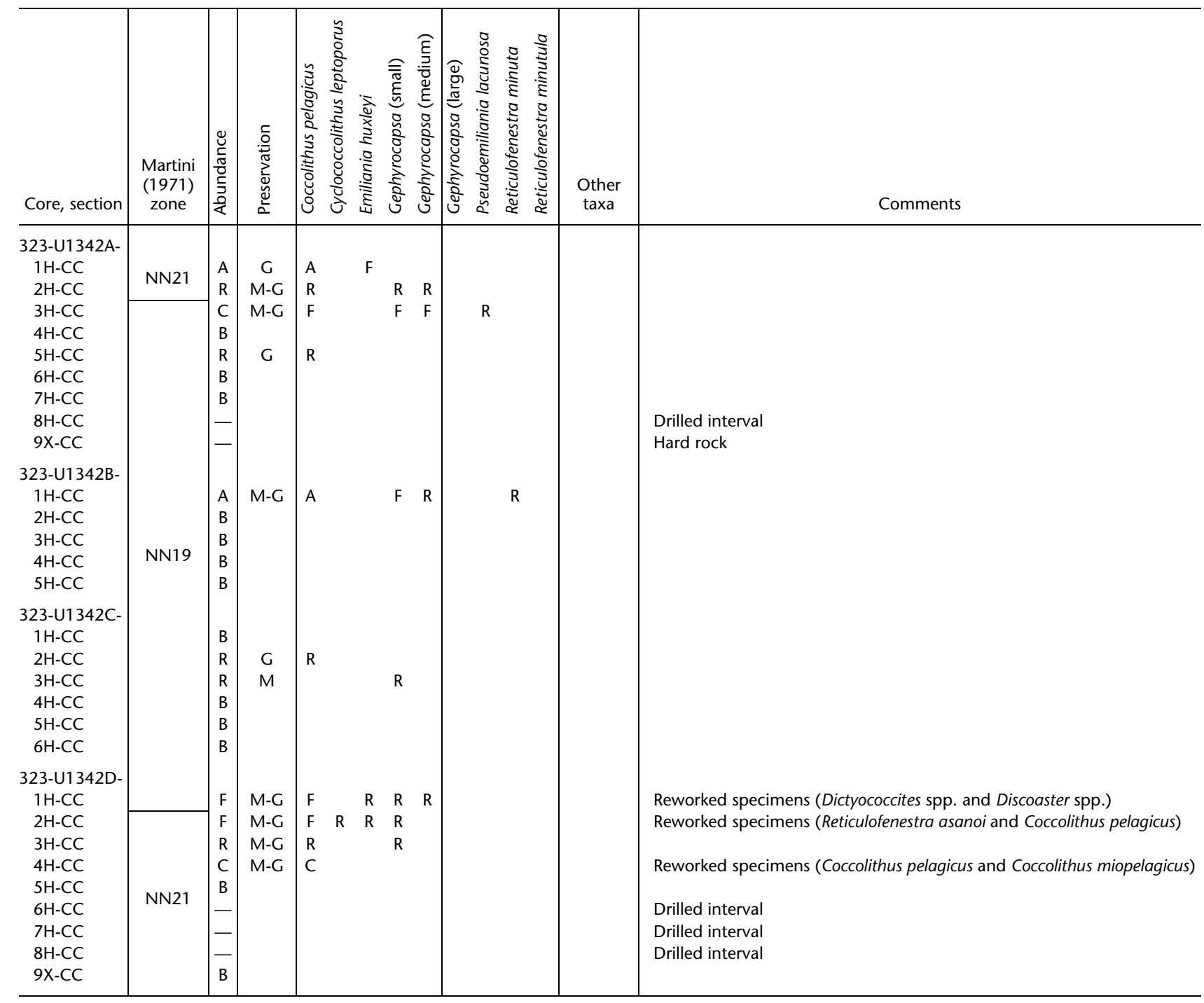

Notes: Abundance: $\mathrm{A}=$ abundant, $\mathrm{C}=$ common, $\mathrm{F}=$ few, $\mathrm{R}=$ rare, $\mathrm{B}=$ barren, $-=$ no sample. Preservation: $\mathrm{G}=\mathrm{good}, \mathrm{M}=$ moderate. 
Table T4. Planktonic foraminifer range chart, Holes U1342A, U1342B, U1342C, and U1342D. (See table notes.)

\begin{tabular}{|c|c|c|c|c|c|c|c|}
\hline $\begin{array}{l}\text { Core, section, } \\
\text { interval }(\mathrm{cm})\end{array}$ & 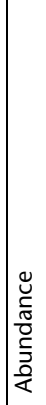 & 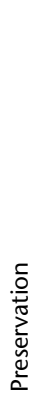 & 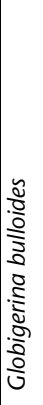 & 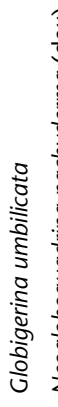 & 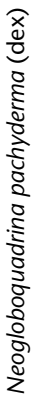 & 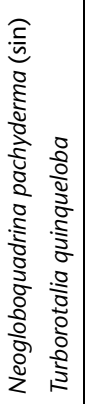 & Other observations \\
\hline \multicolumn{8}{|l|}{ 323-U1342A- } \\
\hline $1 \mathrm{H}-\mathrm{CC}$ & $\mathrm{D}$ & G & A & & & $\mathrm{D}$ & $\begin{array}{l}\text { Dominant foraminiters, abundant diatoms, few sponge spicules, rare rock fragments } \\
\text { Dominant foraminifers, abundant rock fragments, rare sponge spicules }\end{array}$ \\
\hline $2 \mathrm{H}-\mathrm{CC}$ & A & G & $\mathrm{F}$ & & & A & Dominant sand, abundant sponge spicules \\
\hline $3 \mathrm{H}-\mathrm{CC}$ & D & G & & & A & $\mathrm{D}$ & Dominant foraminifers, abundant rock fragments, rare sponge spicules \\
\hline $4 \mathrm{H}-\mathrm{CC}$ & A & G & $\mathrm{F}$ & $\mathrm{P}$ & $\mathrm{F}$ & $\mathrm{F}$ & Dominant sand, abundant sponge spicules, few bubble-walled glass shards \\
\hline $5 \mathrm{H}-\mathrm{CC}$ & B & & & & & & Dominant sand, glauconite, rare sponge spicules \\
\hline $6 \mathrm{H}-\mathrm{CC}$ & B & & & & & & Dominant sand, glauconite, rare sponge spicules \\
\hline 7H-CC & B & & & & & & Dominant sand, glauconite, rare sponge spicules \\
\hline \multicolumn{8}{|l|}{ 323-U1342B- } \\
\hline Mudline & $\mathrm{D}$ & G & $\mathrm{R}$ & & & $\mathrm{D}$ & Dominant foraminifers, few diatoms \\
\hline $1 \mathrm{H}-\mathrm{CC}$ & D & G & $\mathrm{R}$ & $\mathrm{R}$ & & $\mathrm{D}$ & Dominant foraminifers \\
\hline $2 \mathrm{H}-\mathrm{CC}$ & A & G & $\mathrm{F}$ & $\mathrm{p}$ & $\mathrm{R}$ & A & Dominant sand, abundant sponge spicules \\
\hline $3 \mathrm{H}-\mathrm{CC}$ & $\mathrm{F}$ & G & $\mathrm{R}$ & $\mathrm{P}$ & $\mathrm{F}$ & $\mathrm{F}$ & Dominant sand, abundant sponge spicules \\
\hline $4 \mathrm{H}-\mathrm{CC}$ & $\mathrm{R}$ & M & & & $\mathrm{R}$ & $\mathrm{R}$ & Dominant sand, abundant sponge spicules, few bubble-walled glass shards \\
\hline $5 \mathrm{H}-\mathrm{CC}$ & B & & & & & & Dominant sand, abundant sponge spicules, few bubble-walled glass shards \\
\hline \multicolumn{8}{|l|}{ 323-U1342C- } \\
\hline Mudline & D & VG & $\mathrm{F}$ & & & $\mathrm{D}$ & Dominant foraminifers, few diatoms \\
\hline $1 \mathrm{H}-\mathrm{CC}$ & D & VG & $\mathrm{R}$ & & & $\mathrm{D}$ & Dominant foraminifers \\
\hline $2 \mathrm{H}-2 \mathrm{~W}, 24-26$ & D & G & $\mathrm{R}$ & $\mathrm{R}$ & & $\mathrm{D}$ & Dominant foraminifers, abundant large bivalve fragments, abundant diatoms \\
\hline $2 \mathrm{H}-\mathrm{CC}$ & A & $\mathrm{G}$ & $\mathrm{R}$ & $\mathrm{P}$ & & A & Dominant sand, abundant sponge spicules, few bubble-walled glass shards \\
\hline $3 \mathrm{H}-\mathrm{CC}$ & A & G & & & & A & Dominant sand, abundant sponge spicules, few bubble-walled glass shards \\
\hline $4 \mathrm{H}-\mathrm{CC}$ & A & $\mathrm{G}$ & $\mathrm{R}$ & & $\mathrm{R}$ & A & Dominant sand, abundant sponge spicules \\
\hline $5 \mathrm{H}-\mathrm{CC}$ & B & & & & & & Dominant rock fragments with "breadcrust"-like surface, abundant sponge spicules and frames \\
\hline $6 \mathrm{H}-\mathrm{CC}$ & B & & & & & & Dominant sand, glauconite, rare sponge spicules \\
\hline \multicolumn{8}{|l|}{ 323-U1342D- } \\
\hline Mudline & D & VG & $\mathrm{R}$ & $\mathrm{R}$ & & D $P$ & Dominant foraminifers, abundant diatoms, few sponge spicules, rare sand \\
\hline $1 \mathrm{H}-\mathrm{CC}$ & D & VG & $\mathrm{R}$ & $\mathrm{R}$ & & $\mathrm{D}$ & Dominant foraminifers \\
\hline $2 \mathrm{H}-\mathrm{CC}$ & A & VG & $\mathrm{F}$ & $\mathrm{F}$ & $\mathrm{P}$ & $\mathrm{D}$ & Dominant sand, abundant sponge spicules \\
\hline $3 \mathrm{H}-\mathrm{CC}$ & $\mathrm{F}$ & G & $\mathrm{R}$ & & & $\mathrm{F}$ & Dominant sand, abundant sponge spicules \\
\hline $4 \mathrm{H}-\mathrm{CC}$ & D & $\mathrm{G}$ & A & & $\mathrm{F}$ & A & Dominant foraminifers \\
\hline $5 \mathrm{H}-\mathrm{CC}$ & $\mathrm{P}$ & G & $\mathrm{P}$ & & & & Dominant sand, glauconite, rare sponge spicules \\
\hline 9X-CC & B & & & & & & Rock fragments \\
\hline
\end{tabular}

Notes: Abundance: $\mathrm{D}=$ dominant, $\mathrm{A}=$ abundant, $\mathrm{F}=$ few, $\mathrm{R}=$ rare, $\mathrm{P}=$ present, $\mathrm{B}=$ barren. Preservation: $\mathrm{VG}=$ very good, $\mathrm{G}=$ good, $\mathrm{M}=\mathrm{moder}-$ ate. Dex $=$ dextral, $\sin =$ sinistral. 


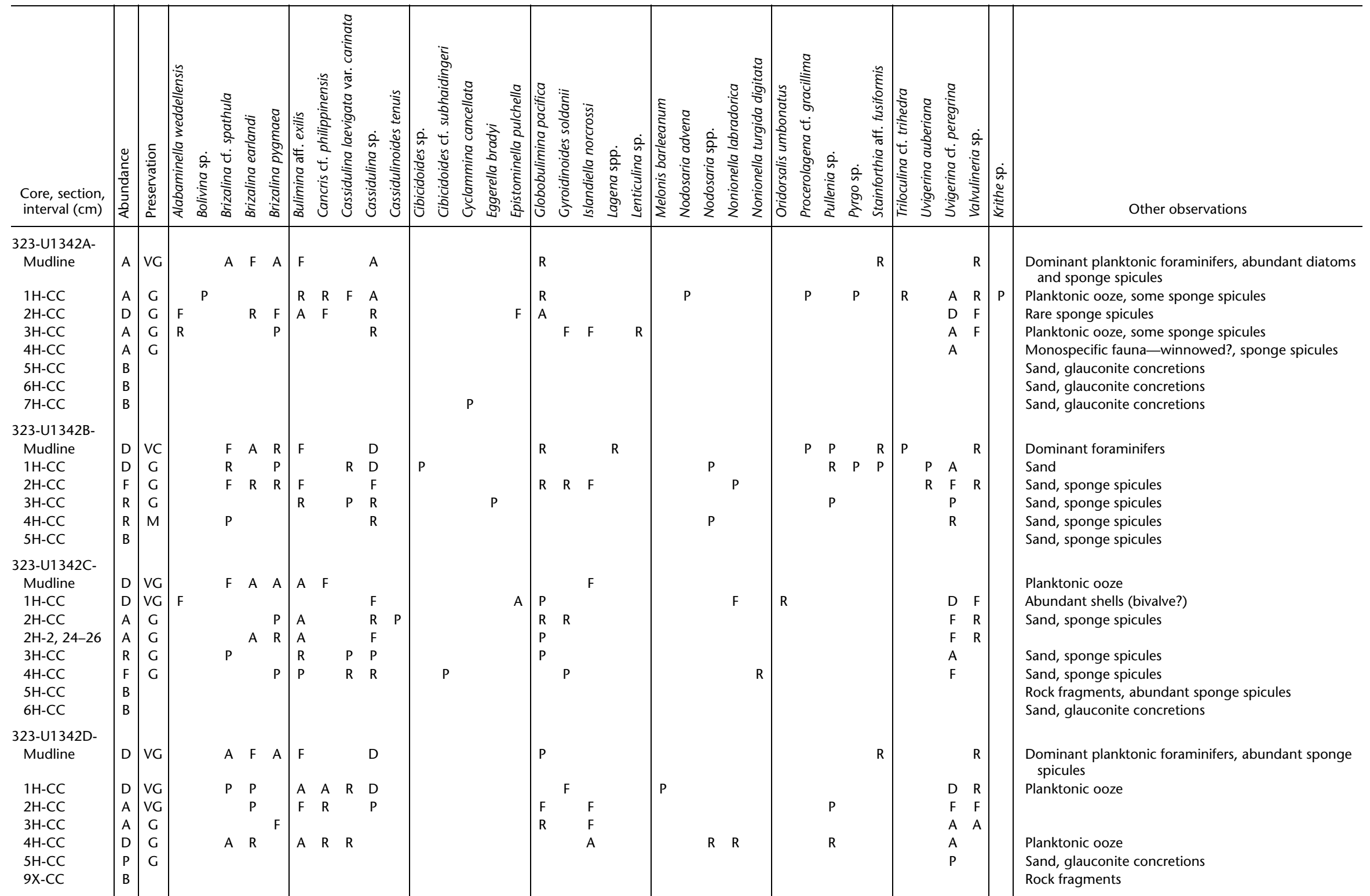

Notes: Abundance: $\mathrm{D}=$ dominant, $\mathrm{A}=$ abundant, $\mathrm{F}=$ few $\mathrm{R}=$ rare, $\mathrm{P}=$ present, $\mathrm{B}=$ barren. Preservation: $\mathrm{VG}=$ very good, $\mathrm{G}=$ good, $\mathrm{M}=\mathrm{moderate}$. 
Table T7. Silicoflagellate and ebridian range chart, Holes U1342A and U1342D. (See table notes.)

\begin{tabular}{|c|c|c|c|c|c|c|c|c|c|c|c|c|c|c|c|}
\hline \multirow[b]{3}{*}{ Core, section } & & & \multirow{3}{*}{ 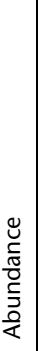 } & \multirow{3}{*}{ 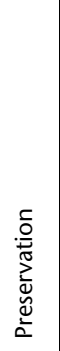 } & \multicolumn{9}{|c|}{ Silicoflagellates } & \multirow{3}{*}{ 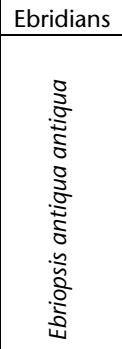 } & \multirow{3}{*}{$\begin{array}{c}\text { Zone in } \\
\text { Ling (1992) }\end{array}$} \\
\hline & \multicolumn{2}{|c|}{ Depth (mbsf) } & & & 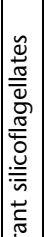 & 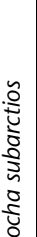 & 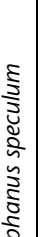 & 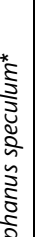 & 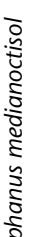 & 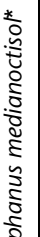 & 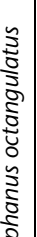 & 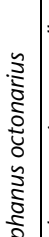 & 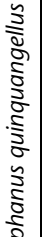 & & \\
\hline & Top & Bottom & & & 选 & : & 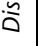 & 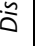 & $\frac{5}{0}$ & $\frac{\omega}{0}$ & 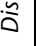 & $\frac{5}{0}$ & $\frac{0}{0}$ & & \\
\hline \multicolumn{16}{|l|}{ 323-U1342A- } \\
\hline $1 \mathrm{H}-\mathrm{CC}$ & 1.65 & 1.75 & B & & & & & & & & & & & & \\
\hline $2 \mathrm{H}-\mathrm{CC}$ & 11.31 & 11.41 & C & M-G & & $\mathrm{T}$ & $\mathrm{T}$ & & & & $\mathrm{F}$ & $\mathrm{F}$ & & & \\
\hline $3 \mathrm{H}-\mathrm{CC}$ & 20.91 & 21.01 & $\mathrm{R}$ & P-M & & & & & & & $\mathrm{R}$ & & & & \\
\hline $4 \mathrm{H}-\mathrm{CC}$ & 30.65 & 30.75 & C & M & & C & $\mathrm{R}$ & $\mathrm{R}$ & $\mathrm{R}$ & & & & & & Undefined \\
\hline $5 \mathrm{H}-\mathrm{CC}$ & 40.12 & 40.22 & $\mathrm{~F}$ & M & $\mathrm{T}$ & & $\mathrm{R}$ & $\mathrm{R}$ & & & & & & & \\
\hline $6 \mathrm{H}-\mathrm{CC}$ & 48.25 & 48.35 & B & & & & & & & & & & & & \\
\hline 7H-CC & 55.64 & 55.74 & $\mathrm{~F}$ & M & & & $\mathrm{R}$ & $\mathrm{R}$ & & & & & $\mathrm{R}$ & $\mathrm{R}$ & \\
\hline \multicolumn{16}{|l|}{ 323-U1342D- } \\
\hline $1 \mathrm{H}-\mathrm{CC}$ & 6.01 & 6.11 & $\mathrm{R}$ & P-M & & & & & & & $\mathrm{R}$ & & & & \\
\hline $2 \mathrm{H}-\mathrm{CC}$ & 15.73 & 15.83 & $\mathrm{~F}$ & M & & & $\mathrm{F}$ & & & T & & & & & \\
\hline $3 \mathrm{H}-\mathrm{CC}$ & 25.02 & 25.12 & B & & & & & & & & & & & & Undefined \\
\hline $4 \mathrm{H}-\mathrm{CC}$ & 34.73 & 34.83 & C & M-G & $\mathrm{T}$ & $\mathrm{R}$ & $\mathrm{R}$ & & T & $\mathrm{R}$ & & C & & & \\
\hline $5 \mathrm{H}-\mathrm{CC}$ & 44.30 & 44.40 & $\mathrm{R}$ & M-G & & & $\mathrm{R}$ & & & & & & & $\mathrm{R}$ & \\
\hline
\end{tabular}

Notes: * $=$ with short radial spines. Abundance: $\mathrm{C}=$ common, $\mathrm{F}=$ few, $\mathrm{R}=$ rare, $\mathrm{T}=$ trace, $\mathrm{B}=$ barren. Preservation: $\mathrm{G}=$ good, $\mathrm{M}=\mathrm{moderate}, \mathrm{P}=$ poor. 
Table T8. Radiolarian datum events, Holes U1342A, U1342B, U1342C, and U1342D. (See table note.)

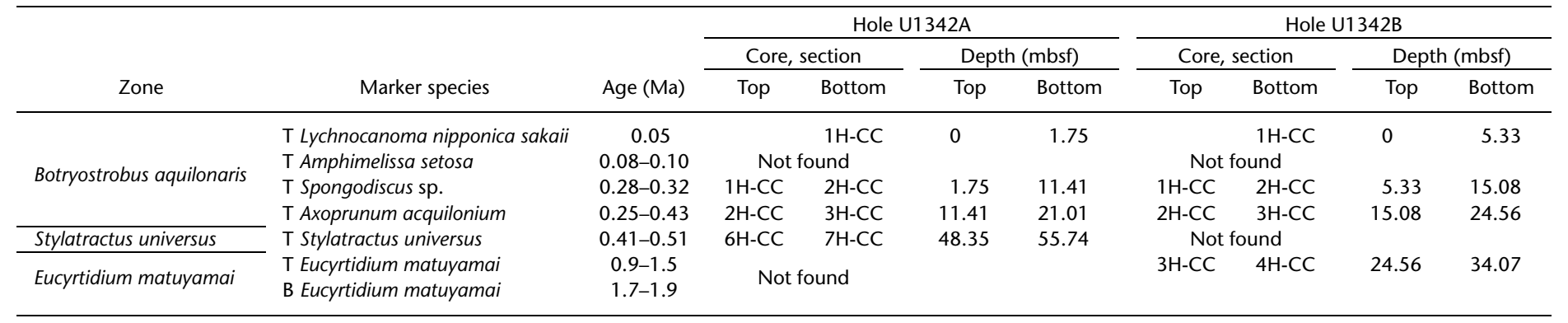

Note: $\mathrm{T}=$ top, $\mathrm{B}=$ bottom.

Table T8 (continued).

\begin{tabular}{|c|c|c|c|c|c|c|c|c|c|c|}
\hline \multirow{2}{*}{ Zone } & \multirow{2}{*}{ Marker species } & \multirow{2}{*}{ Age (Ma) } & \multicolumn{4}{|c|}{ Hole U1342C } & \multicolumn{4}{|c|}{ Hole U1342D } \\
\hline & & & \multicolumn{2}{|c|}{ Core, section } & \multicolumn{2}{|c|}{ Depth (mbsf) } & \multicolumn{2}{|c|}{ Core, section } & \multicolumn{2}{|c|}{ Depth (mbsf) } \\
\hline \multirow{3}{*}{ Botryostrobus aquilonaris } & T Lychnocanoma nipponica sakaii & 0.05 & & $1 \mathrm{H}-\mathrm{CC}$ & 0 & 7.19 & & $1 \mathrm{H}-\mathrm{CC}$ & 0 & 6.11 \\
\hline & T Spongodiscus sp. & $0.28-0.32$ & $1 \mathrm{H}-\mathrm{CC}$ & $2 \mathrm{H}-\mathrm{CC}$ & 7.19 & 17.04 & $1 \mathrm{H}-\mathrm{CC}$ & $2 \mathrm{H}-\mathrm{CC}$ & 6.11 & 15.83 \\
\hline & T Axoprunum acquilonium & $0.25-0.43$ & $1 \mathrm{H}-\mathrm{CC}$ & $2 \mathrm{H}-\mathrm{CC}$ & 7.19 & 17.04 & $2 \mathrm{H}-\mathrm{CC}$ & $3 \mathrm{H}-\mathrm{CC}$ & 15.83 & 25.12 \\
\hline Stylatractus universus & T Stylatractus universus & $0.41-0.51$ & \multicolumn{2}{|c|}{ Not found } & & & \multicolumn{2}{|c|}{ Not found } & & \\
\hline
\end{tabular}


Table T9. Radiolarian range chart, Holes U1342A, U1342B, U1342C, and U1342D. (See table notes.)

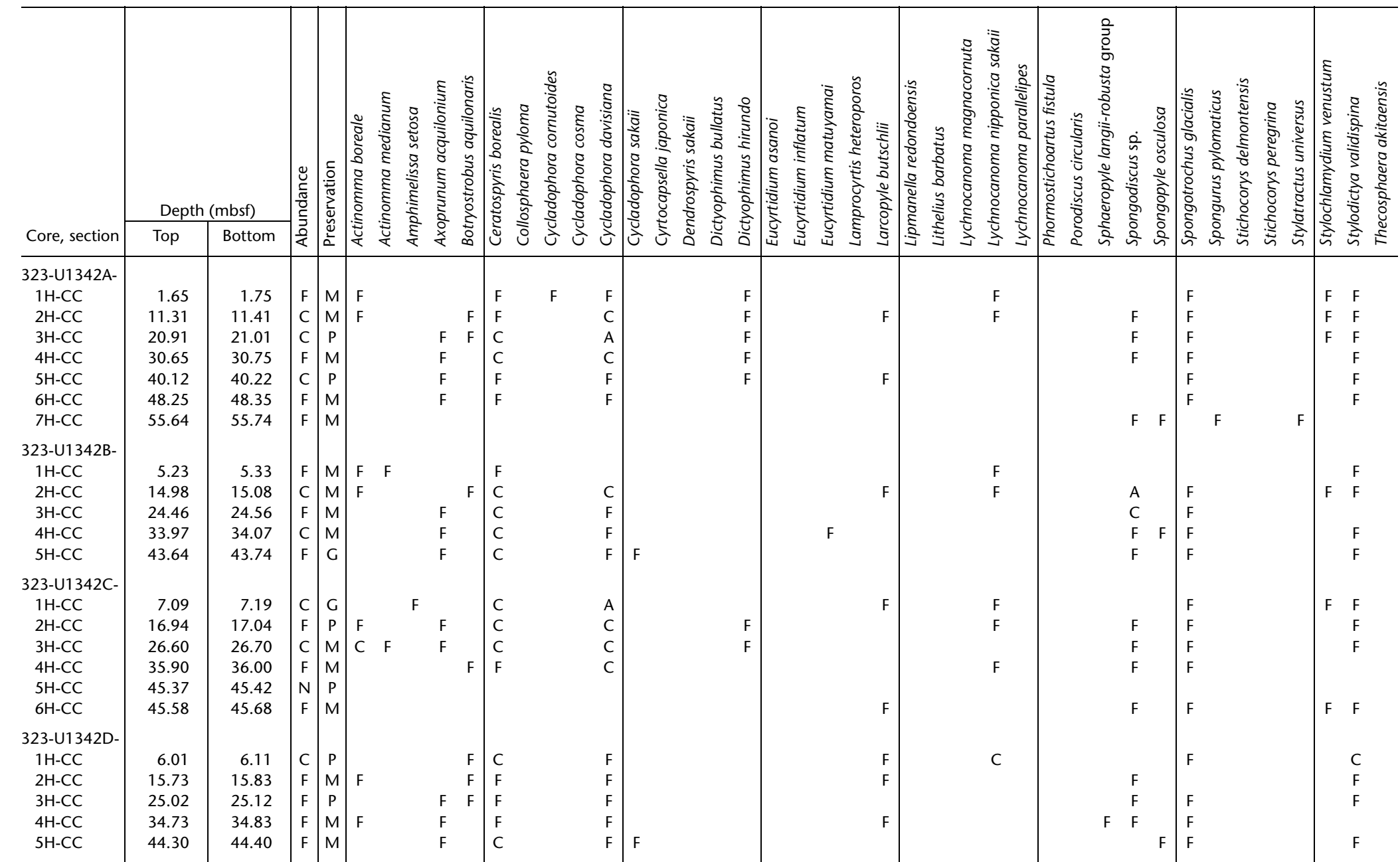

Notes: Abundance: $\mathrm{A}=$ abundant, $\mathrm{F}=$ few $\mathrm{C}=$ common, $\mathrm{N}=$ none. Preservation: $\mathrm{G}=$ good, $\mathrm{M}=$ moderate, $\mathrm{P}=$ poor. 
Table T10. Dinoflagellate cyst, pollen, and palynomorph range chart, Holes U1342A and U1342B. (See table notes.)

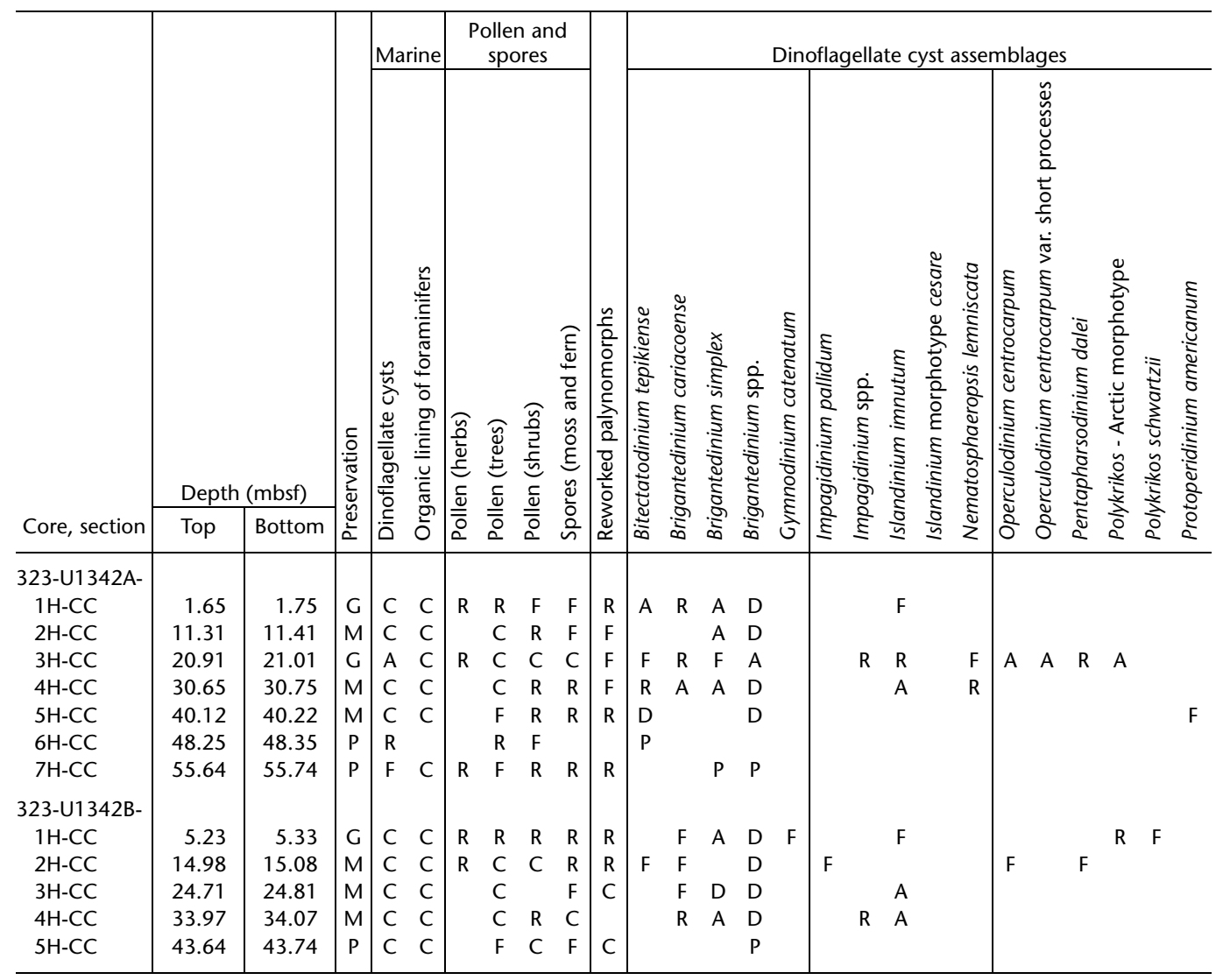

Notes: Preservation: $G=$ good, $M=$ moderate, $P=$ poor. Absolute abundance: $A=$ abundant $\left(>2000 / \mathrm{cm}^{3}\right), C=\operatorname{common}\left(>200 / \mathrm{cm}^{3}\right), F=$ few $\left(>100 / \mathrm{cm}^{3}\right), \mathrm{R}=$ rare $\left(<100 / \mathrm{cm}^{3}\right)$. Relative abundance of dinoflagellate cysts: $\mathrm{D}=$ dominant $(>30 \%), A=$ abundant $(>10 \%), F=$ few $(>5 \%), R$ $=$ rare $(<5 \%), \mathrm{P}=$ occurrence (when counts are $<20$ ).

Table T11. Chron ages and preliminary depths, Holes U1342A, U1342C, and U1342D. (See table notes.)

\begin{tabular}{|c|c|c|c|c|c|c|c|c|c|c|}
\hline \multirow[b]{2}{*}{ Event } & \multirow[b]{2}{*}{$\begin{array}{l}\text { Age } \\
\text { (ka) }\end{array}$} & \multicolumn{3}{|c|}{ Hole U1342A } & \multicolumn{3}{|c|}{ Hole U1342C } & \multicolumn{3}{|c|}{ Hole U1342D } \\
\hline & & $\begin{array}{l}\text { Core, section, } \\
\text { interval }(\mathrm{cm})\end{array}$ & $\begin{array}{l}\text { Depth } \\
\text { (mbsf) }\end{array}$ & $\begin{array}{l}\text { Sed. rate } \\
(\mathrm{cm} / \mathrm{k} . \mathrm{y} .)\end{array}$ & $\begin{array}{l}\text { Core, section, } \\
\text { interval }(\mathrm{cm})\end{array}$ & $\begin{array}{l}\text { Depth } \\
\text { (mbsf) }\end{array}$ & $\begin{array}{l}\text { Sed. rate } \\
(\mathrm{cm} / \text { k.y. })\end{array}$ & $\begin{array}{l}\text { Core, section, } \\
\text { interval }(\mathrm{cm})\end{array}$ & $\begin{array}{l}\text { Depth } \\
\text { (mbsf) }\end{array}$ & $\begin{array}{l}\text { Sed. rate } \\
(\mathrm{cm} / \text { k.y. })\end{array}$ \\
\hline & & 323-U1342A- & & & 323-U1342C- & & & 323-U1342D- & & \\
\hline & 0 & & 0 & 3.2 & & 0 & 3.2 & & 0 & 3.2 \\
\hline B Brunhes & 781 & $4 \mathrm{H}-3,110$ & 24.9 & 2.3 & $3 \mathrm{H}-6,90$ & 25.1 & 1.8 & $3 \mathrm{H}-7,30$ & 24.8 & 2.1 \\
\hline Kamikatsura Excursion & 885 & $4 \mathrm{H}-5,45$ & 27.25 & 3.3 & $4 \mathrm{H}-1,80$ & 27 & 4.4 & $4 \mathrm{H}-2,50$ & 27 & 3.3 \\
\hline Santa Rosa Excursion & 930 & & & & $4 \mathrm{H}-2,130$ & 29 & 2.5 & $4 \mathrm{H}-3,50$ & 28.5 & 2.6 \\
\hline T jaramillo & 998 & & & & $4 \mathrm{H}-4(\mathrm{~T})$ & 30.7 & 5.1 & $4 \mathrm{H}-4,80$ & 30.3 & 5.0 \\
\hline B Jaramillo & 1072 & $5 \mathrm{H}-3,15$ & 33.45 & 4.3 & $4 \mathrm{H}-6,75$ & 34.45 & 3.4 & $4 \mathrm{H}-7(\mathrm{~T})$ & 34 & 4.2 \\
\hline Punaruu Excursion & 1125 & $5 \mathrm{H}-4,95$ & 35.75 & 9.4 & $5 \mathrm{H}-1,52.5$ & 36.25 & 7.9 & $5 \mathrm{H}-2,25$ & 36.25 & 7.6 \\
\hline T Cobb Mountain & 1173 & $6 \mathrm{H}-1,45$ & 40.25 & 10.4 & $5 \mathrm{H} 3,135$ & 40.05 & 7.1 & $5 \mathrm{H}-4,90$ & 39.9 & 5.8 \\
\hline B Cobb Mountain & 1185 & $6 \mathrm{H}-2,20$ & 41.5 & & $5 \mathrm{H}-4,70$ & 40.9 & & $5 \mathrm{H}-5,10$ & 40.6 & \\
\hline
\end{tabular}

Notes: $B=$ bottom, $\mathrm{T}=$ top. Sed. rate $=$ sedimentation rate. 
Table T12. Depths of possible dissolved magnetic grains, U1342A. (See table note.)

\begin{tabular}{|c|c|c|}
\hline $\begin{array}{l}\text { Depth } \\
\text { (mbsf) }\end{array}$ & $\begin{array}{c}\text { Corresponding } \\
\text { MIS }\end{array}$ & Comments \\
\hline $10.6-11.0$ & 9 & Large decrease in intensity \\
\hline $13.2-13.6$ & 11 & Large decrease in intensity \\
\hline $15.1-15.4$ & 13 & Large decrease in intensity \\
\hline $18.1-18.4$ & 15 & Moderate decrease in intensity \\
\hline $20.8-21.2$ & 17 & Large decrease in intensity \\
\hline $21.4-22.0$ & 17 & Large decrease in intensity \\
\hline $25.8-26.2$ & 19 & Large decrease in intensity \\
\hline $28.2-28.9$ & 25 & Large decrease in intensity \\
\hline $30.8-32.3$ & 29 & Largest decrease in intensity \\
\hline
\end{tabular}

Note: MIS = marine isotope stage

Table T13. Depths of possible authigenic magnetic minerals or ash, Hole U1342A. (See table notes.)

\begin{tabular}{rcl}
\hline $\begin{array}{r}\text { Depth } \\
\text { (mbsf) }\end{array}$ & $\begin{array}{c}\text { Corresponding } \\
\text { MIS }\end{array}$ & \multicolumn{1}{c}{ Comments } \\
\hline 1.35 & 2 & Increase in MS only \\
5.20 & 6 & \\
24.70 & 18 & \\
27.85 & 22 & Increase in MS only \\
41.50 & & Increase in remanence, not in MS \\
43.80 & & Increase in remanence, not in MS \\
\hline
\end{tabular}

Notes: $\mathrm{MIS}=$ marine isotope stage. $\mathrm{MS}=$ magnetic susceptibility.

Table T14. Moisture and density, Hole U1342C.

\begin{tabular}{|c|c|c|c|c|c|c|c|}
\hline \multirow{2}{*}{$\begin{array}{l}\text { Core, section, } \\
\text { interval }(\mathrm{cm})\end{array}$} & \multirow{2}{*}{$\begin{array}{l}\text { Depth } \\
\text { (mbsf) }\end{array}$} & \multicolumn{3}{|c|}{ Density $\left(\mathrm{g} / \mathrm{cm}^{3}\right)$} & \multirow{2}{*}{$\begin{array}{l}\text { Void } \\
\text { ratio }\end{array}$} & \multirow{2}{*}{$\begin{array}{c}\text { Water } \\
\text { content } \\
(\%)\end{array}$} & \multirow{2}{*}{$\begin{array}{c}\text { Porosity } \\
(\%)\end{array}$} \\
\hline & & Dry grain & Wet bulk & Dry bulk & & & \\
\hline \multicolumn{8}{|l|}{ 323-U1342C- } \\
\hline $1 \mathrm{H}-1,29-31$ & 0.3 & 2.81 & 1.40 & 0.62 & 3.80 & 55.76 & 79.19 \\
\hline $1 \mathrm{H}-3,29-31$ & 3.3 & 2.52 & 1.42 & 0.68 & 2.86 & 51.74 & 74.10 \\
\hline $1 \mathrm{H}-5,29-31$ & 6.3 & 2.73 & 1.50 & 0.78 & 2.67 & 48.08 & 72.74 \\
\hline $2 \mathrm{H}-1,29-31$ & 7.5 & 2.63 & 1.53 & 0.84 & 2.23 & 44.71 & 69.02 \\
\hline $2 \mathrm{H}-3,29-31$ & 10.5 & 2.69 & 1.54 & 0.86 & 2.25 & 44.36 & 69.23 \\
\hline $2 \mathrm{H}-5,29-31$ & 13.5 & 2.64 & 1.52 & 0.84 & 2.28 & 45.14 & 69.54 \\
\hline $3 \mathrm{H}-1,29-31$ & 17.0 & 2.72 & 1.65 & 1.03 & 1.72 & 37.86 & 63.26 \\
\hline $3 \mathrm{H}-3,29-31$ & 20.0 & 2.58 & 1.57 & 0.92 & 1.89 & 41.19 & 65.34 \\
\hline $3 \mathrm{H}-5,29-31$ & 23.0 & 2.58 & 1.39 & 0.64 & 3.28 & 54.37 & 76.63 \\
\hline $4 \mathrm{H}-1,29-31$ & 26.5 & 2.52 & 1.41 & 0.68 & 2.88 & 51.88 & 74.23 \\
\hline $4 \mathrm{H}-3,29-31$ & 29.5 & 2.52 & 1.29 & 0.48 & 4.69 & 63.10 & 82.44 \\
\hline $4 \mathrm{H}-5,29-31$ & 32.5 & 2.22 & 1.21 & 0.37 & 5.49 & 69.20 & 84.59 \\
\hline $5 \mathrm{H}-1,29-31$ & 36.0 & 2.74 & 1.67 & 1.05 & 1.68 & 37.13 & 62.68 \\
\hline $5 \mathrm{H}-3,29-31$ & 39.0 & 2.62 & 1.79 & 1.28 & 1.09 & 28.76 & 52.14 \\
\hline $5 \mathrm{H}-5,29-31$ & 42.0 & 2.70 & 1.75 & 1.18 & 1.34 & 32.40 & 57.27 \\
\hline
\end{tabular}


Table T15. Affine table indicating the amount that each core in each hole needs to be offset in order to construct a continuous record, Site U1342. (See table note.)

\begin{tabular}{|c|c|c|c|c|c|c|c|}
\hline \multirow[b]{2}{*}{ Core } & \multicolumn{2}{|c|}{ Depth (mbsf) } & \multirow{2}{*}{$\begin{array}{l}\text { Offset } \\
(\mathrm{m})\end{array}$} & \multicolumn{2}{|c|}{ Depth CCSF-A (m) } & \multirow{2}{*}{$\begin{array}{l}\text { Recovered } \\
\text { (m) }\end{array}$} & \multirow{2}{*}{$\begin{array}{c}\text { Recovery } \\
\text { (\%) }\end{array}$} \\
\hline & Top & Bottom & & Top & Bottom & & \\
\hline \multicolumn{8}{|c|}{ 323-U1342A- } \\
\hline $1 \mathrm{H}$ & 0.00 & 1.80 & 0.00 & 0.00 & 1.80 & 1.75 & 97 \\
\hline $2 \mathrm{H}$ & 1.80 & 11.30 & 0.55 & 2.35 & 11.85 & 9.61 & 101 \\
\hline $3 \mathrm{H}$ & 11.30 & 20.80 & 1.01 & 12.31 & 21.81 & 9.71 & 102 \\
\hline $4 \mathrm{H}$ & 20.80 & 30.30 & 1.47 & 22.27 & 31.77 & 9.95 & 105 \\
\hline $5 \mathrm{H}$ & 30.30 & 39.80 & 2.20 & 32.50 & 42.00 & 9.92 & 104 \\
\hline $6 \mathrm{H}$ & 39.80 & 48.30 & 2.78 & 42.58 & 51.08 & 8.55 & 101 \\
\hline $7 \mathrm{H}$ & 48.30 & 49.30 & 2.78 & 51.08 & 52.08 & 7.44 & 744 \\
\hline $8 \mathrm{D}$ & 49.30 & 52.30 & - & - & - & 0.00 & 0 \\
\hline $9 X$ & 52.30 & 53.30 & - & - & - & 0.46 & 46 \\
\hline \multicolumn{8}{|c|}{ 323-U1342B- } \\
\hline $1 \mathrm{H}$ & 0.00 & 5.30 & 0.07 & 0.07 & 5.37 & 5.33 & 101 \\
\hline $2 \mathrm{H}$ & 5.30 & 14.80 & 0.04 & 5.34 & 14.84 & 9.78 & 103 \\
\hline $3 \mathrm{H}$ & 14.80 & 24.30 & 0.94 & 15.74 & 25.24 & 10.01 & 105 \\
\hline $4 \mathrm{H}$ & 24.30 & 33.80 & 1.50 & 25.80 & 35.30 & 9.77 & 103 \\
\hline $5 \mathrm{H}$ & 33.80 & 43.30 & 2.27 & 36.07 & 45.57 & 9.94 & 105 \\
\hline \multicolumn{8}{|c|}{ 323-U1342C- } \\
\hline $1 \mathrm{H}$ & 0.00 & 7.20 & -0.03 & -0.03 & 7.17 & 7.22 & 100 \\
\hline $2 \mathrm{H}$ & 7.20 & 16.70 & 0.01 & 7.21 & 16.71 & 9.84 & 104 \\
\hline $3 \mathrm{H}$ & 16.70 & 26.20 & 1.14 & 17.84 & 27.34 & 9.67 & 102 \\
\hline $4 \mathrm{H}$ & 26.20 & 35.70 & 1.12 & 27.32 & 36.82 & 9.80 & 103 \\
\hline $5 \mathrm{H}$ & 35.70 & 45.20 & 2.03 & 37.73 & 47.23 & 9.98 & 105 \\
\hline $6 \mathrm{H}$ & 45.20 & 45.40 & - & - & - & 0.22 & 110 \\
\hline \multicolumn{8}{|c|}{ 323-U1342D- } \\
\hline $1 \mathrm{H}$ & 0.00 & 6.00 & -0.01 & -0.01 & 5.99 & 6.11 & 102 \\
\hline $2 \mathrm{H}$ & 6.00 & 15.50 & 0.59 & 6.59 & 16.09 & 9.83 & 103 \\
\hline $3 \mathrm{H}$ & 15.50 & 25.00 & 1.31 & 16.81 & 26.31 & 9.62 & 101 \\
\hline $4 \mathrm{H}$ & 25.00 & 34.50 & 1.61 & 26.61 & 36.11 & 9.83 & 103 \\
\hline $5 \mathrm{H}$ & 34.50 & 44.00 & 2.36 & 36.86 & 46.36 & 9.90 & 104 \\
\hline $6 \mathrm{D}$ & 44.00 & 62.60 & - & - & - & 0.00 & 0 \\
\hline $7 X$ & 62.60 & 66.60 & - & - & - & 0.55 & 14 \\
\hline $8 X$ & 66.60 & 71.60 & - & - & - & 1.66 & 33 \\
\hline $9 X$ & 71.60 & 75.60 & - & - & - & 3.84 & 96 \\
\hline $10 x$ & 75.60 & 82.10 & - & - & - & 4.66 & 72 \\
\hline $11 x$ & 82.10 & 87.90 & - & - & - & 3.34 & 58 \\
\hline $12 X$ & 87.90 & 90.10 & - & - & - & 2.01 & 91 \\
\hline $13 x$ & 90.10 & 94.90 & - & - & - & 4.64 & 97 \\
\hline $14 X$ & 94.90 & 102.50 & - & - & - & 3.48 & 46 \\
\hline $15 X$ & 102.50 & 106.10 & - & - & - & 1.48 & 41 \\
\hline $16 X$ & 106.10 & 115.10 & - & - & - & 2.49 & 28 \\
\hline $17 X$ & 115.10 & 117.70 & - & - & - & 5.70 & 219 \\
\hline $18 X$ & 117.70 & 121.70 & - & - & - & 3.00 & 75 \\
\hline $19 X$ & 121.70 & 127.70 & - & - & - & 4.23 & 70 \\
\hline
\end{tabular}

Note: $-=$ not applicable.

Table T16. Splice table indicating tie points between holes, Site U1342. Sampling along the splice should be used to construct a continuous record.

\begin{tabular}{|c|c|c|c|c|c|c|}
\hline \multirow[b]{2}{*}{$\begin{array}{l}\text { Hole, core, section, } \\
\text { interval }(\mathrm{cm})\end{array}$} & \multicolumn{2}{|c|}{ Depth } & & \multirow[b]{2}{*}{$\begin{array}{l}\text { Hole, core, section, } \\
\text { interval }(\mathrm{cm})\end{array}$} & \multicolumn{2}{|c|}{ Depth } \\
\hline & mbsf & $\begin{array}{c}\text { CCSF-D } \\
(\mathrm{m})\end{array}$ & & & mbsf & $\begin{array}{l}\text { CCSF-D } \\
(\mathrm{m})\end{array}$ \\
\hline $323-$ & & & & $323-$ & & \\
\hline U1342D-1H-4, 75.1 & 5.25 & 5.24 & Tie to & U1342A-2H-2, 139.8 & 4.70 & 5.24 \\
\hline U1342A-2H-7, 16.1 & 10.96 & 11.51 & Tie to & U1342C-2H-3, 130.2 & 11.50 & 11.51 \\
\hline U1342C-2H-7, 28.2 & 16.48 & 16.49 & Tie to & U1342A-3H-3, 118.1 & 15.48 & 16.49 \\
\hline U1342A-3H-6, 125.8 & 20.06 & 21.06 & Tie to & U1342C-3H-3, 22.5 & 19.93 & 21.06 \\
\hline U1342C-3H-7, 34.6 & 26.05 & 27.19 & Tie to & U1342D-4H-1, 57.7 & 25.58 & 27.19 \\
\hline U1342D-4H-7, 5.6 & 34.06 & 35.66 & Tie to & U1342A-5H-3, 16.5 & 33.46 & 35.66 \\
\hline U1342A-5H-6, 103.9 & 38.84 & 41.04 & Tie to & U1342D-5H-3, 117.7 & 38.68 & 41.04 \\
\hline
\end{tabular}


Table T17. Temperature data, Hole U1342C. (See table note.)

\begin{tabular}{lccc}
\hline Core & $\begin{array}{c}\text { Depth } \\
(\mathrm{mbsf})\end{array}$ & $\begin{array}{c}\text { Thermal resistance } \\
\left(\mathrm{m}^{2} \mathrm{~K} / \mathrm{W}\right)\end{array}$ & $\begin{array}{c}T \\
\left({ }^{\circ} \mathrm{C}\right)\end{array}$ \\
\hline $323-\mathrm{U} 1342 \mathrm{C}-$ & & & \\
$3 \mathrm{H}$ & 26.2 & 27.0 & 4.46 \\
$5 \mathrm{H}$ & 35.0 & 37.7 & 5.32 \\
\hline
\end{tabular}

Note: $T=$ formation temperature. 